\title{
Marta Aoki
}

Reabilitação com ênfase no território - demandas de pessoas com deficiências e a promoção da participação comunitária

Dissertação apresentada à Faculdade de Medicina da Universidade de São Paulo para obtenção do título de Mestre em Ciências

Área de Concentração: Movimento, Postura e Ação Humana

Orientadora: Profa. Dra. Fátima Correa Oliver

São Paulo

2009 


\section{Dados Internacionais de Catalogação na Publicação (CIP)}

Preparada pela Biblioteca da

Faculdade de Medicina da Universidade de São Paulo

Creprodução autorizada pelo autor

Aoki, Marta

Reabilitação com ênfase no território - demandas de pessoas com deficiências e promoção da participação comunitária / Marta Aoki. -- São Paulo, 2009.

Dissertação(mestrado)--Faculdade de Medicina da Universidade de São Paulo.

Departamento de Fisioterapia, Fonoaudiologia e Terapia Ocupacional.

Área de concentração: Movimento, Postura e Ação Humana.

Orientadora: Fátima Correa Oliver.

Descritores: 1.Pessoas com deficiência 2.Reabilitação 3.Participação comunitária 4.Terapia ocupacional

USP/FM/SBD-263/09 
Aos meus pais, Jerê e Laís 
Agradecimentos

A minha orientadora Fátima Correa Oliver, pela dedicação e cuidado ao mostrar-me os melhores caminhos para percorrer o trajeto deste estudo.

A querida amiga Stella Maris Nicolau, que, com sua alegria e entusiasmo, sempre me motivou a voar mais alto.

Aos estagiários do curso de Terapia Ocupacional, pela adesão e apoio a mais esta proposta assistencial.

A todos os funcionários da Unidade Básica de Saúde do Jd. Boa Vista que me acolheram com tanto carinho e respeito.

Aos representantes do Centro Comunitário Raposo Tavares, em especial Sinthia e Padre Mário, que acolheram as nossas propostas e nos apoiaram no cotidiano do desenvolvimento do trabalho.

As minhas colegas de mestrado, Renata, Taísa e Vanessa, por compartilharem comigo momentos de inquietações e entusiasmos.

Enfim, a todos que estiveram próximos a mim durante este período tão importante da minha vida, meus amigos, professores, minha família. 
Osmar e Yago, em passeio ao centro da cidade, no ponto de ônibus, cantando:

Viver, e não ter a vergonha de ser feliz Cantar e cantar e cantar

A beleza de ser um eterno aprendiz Ah meu Deus eu sei, eu sei Que a vida devia ser bem melhor e será

Mas isso não impede que eu repita É bonita, é bonita e é bonita (O que é o que é - Gonzaguinha) 


\section{SUMÁRIO}

Resumo

Summary

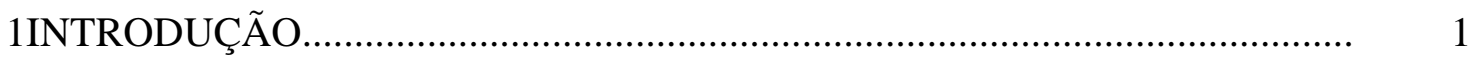

1.1 Deficiência e reabilitação.............................................................................

2 PROCEDIMENTOS METODOLÓGICOS......................................................... 14

2.1 Procedimento de coleta de dados...................................................................... 18

2.2 Procedimento de análise dos dados........................................................... 22

3 COMPREENDER O CONTEXTO: O BAIRRO COHAB RAPOSO TAVARES

4 GRUPO DE CONVIVÊNCIA VIDA NOVA: UMA EXPERIÊNCIA DE PARTICIPAÇÃO COMUNITÁRIA................................................................. 32

4.1 Breves considerações sobre o trabalho em grupos e oficinas terapêuticas....... 34

4.2 A construção da convivência e da participação................................................. 47

4.2.1 Espaço de encontro: Centro Comunitário Raposo Tavares............................ 52

4.2.2 Os participantes do Grupo de Convivência Vida Nova.................................. 55

4.2.3 Estrutura e organização do grupo e a presença dos participantes ................ 68

4.2.4 As motivações para participar e a percepção das potencialidades e limitações.

4.3 O desenvolvimento da experiência: o grupo como possibilidade de promoção de aprendizagem e cuidado.

4.3.1 O grupo como facilitador de processos de comunicação e de estabelecimento de vínculos.

4.3.2 O grupo como oportunidade de discussão de direitos e de circulação social $\quad 110$

4.4 A dimensão de ser terapeuta, coordenador e pesquisador............................... 117

5 VIDA COTIDIANA E DEFICIÊNCIA........................................................... 125

5.1 Habitar e Comer: a necessidade de manutenção da vida.................................. 132

5.2 Trabalhar: uma forma de reconhecimento social............................................. 136

5.3 Conversar: o desejo de romper com o isolamento social................................. 140

5.4 Passear: a possibilidade de conhecer os recursos da cidade............................... 145

6 GRUPO DE CONVIVÊNCIA VIDA NOVA: UMA POSSIBILIDADE DE 154

LIDAR COM AS DEMANDAS

7 CONCLUSÕES

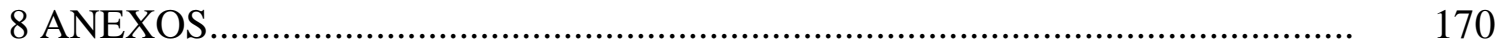

8.1 Anexo 1 - Termo de consentimento................................................................ 171

8.2 Anexo 2 - Roteiro de entrevista.................................................................. 173

8.3 Anexo 3 - Roteiro de observação............................................................... 175

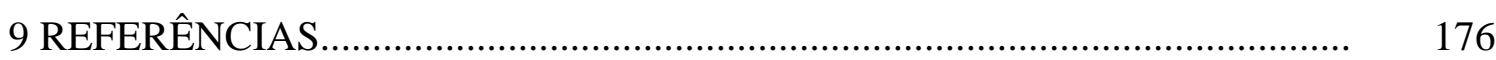




\section{RESUMO}

Aoki M. Reabilitação com ênfase no território - demandas de pessoas com deficiências e a promoção da participação comunitária [dissertação]. São Paulo: Universidade de São Paulo, Faculdade de Medicina; 2009.

Este estudo pretendeu discutir a experiência da implantação de um grupo de convivência para adultos com deficiências, na comunidade, como uma das estratégias de reabilitação no âmbito territorial, realizadas a partir de uma unidade básica de saúde. Os objetivos foram: compreender o processo de grupalização de adultos com deficiências e identificar as transformações ocorridas no âmbito individual e coletivo; conhecer os modos de vida e as demandas dessas pessoas e como um grupo de convivência pode contribuir para responder a tais demandas.Para o estudo de caso, utilizou-se a entrevista semi estruturada e o registro/diário de campo das atividades realizadas e acompanhadas pela pesquisadora.Participaram do grupo 10 adultos com deficiências que vivenciavam situação de pobreza e isolamento social, sendo: seis mulheres e quatro homens. Cinco apresentavam deficiência mental, três deficiência física e duas deficiências múltiplas. As entrevistas foram realizadas com 05 participantes do grupo, que o representavam em termos de idade, sexo e tipo de deficiência e tratavam de assuntos como: atividades cotidianas, experiências em saúde e reabilitação, educação, trabalho e participação comunitária.Foram registrados 34 encontros, durante 8 meses, de março a dezembro de 2006, uma vez por semana, encontros que duravam aproximadamente duas horas. A realização do grupo em um centro comunitário tornou visíveis para a comunidade os problemas enfrentados pelas pessoas com deficiências e promoveu a discussão sobre os direitos sociais. Tanto nas entrevistas quanto nas observações, ficou evidente a falta de autonomia e iniciativa das pessoas para participar das atividades do grupo, assim como para discutir as situações do cotidiano. Estes temas foram tratados no desenvolvimento da rotina do grupo (participação no planejamento das atividades, compra do material, confecção e venda). Participar do grupo promoveu trocas afetivas, a descoberta de habilidades manuais e criativas, o acolhimento, a melhora da auto-estima e da comunicação entre os participantes. Observou-se a organização de um modo de vida peculiar, centrada nas dimensões do habitar e comer (urgências respondidas no dia a dia). Para três dos entrevistados a aquisição da deficiência interrompeu a vida produtiva e a vinculação ao trabalho. Outros aspectos da vida cotidiana como conversar e passear foram demandas importantes na vida dos entrevistados. Estudar, realizar tratamento em reabilitação, ter uma moradia digna e aconchegante, ter alimento, trabalho, benefício previdenciário, locomover-se, passear e conversar foram as principais demandas apresentadas pelos sujeitos. A realização de um grupo de convivência na comunidade foi uma experiência de participação comunitária, de trocas interpessoais e aumento da rede de apoio social das pessoas com deficiências, em contraposição a situação de isolamento social. Grupos de convivência podem ser uma estratégia alternativa para o acompanhamento de pessoas com deficiências na comunidade.

Descritores: 1.pessoas com deficiência 2. Reabilitação 3.Participação comunitária 4.Terapia ocupacional 


\section{SUMMARY}

Aoki M. Community-based rehabilitation - the demands of people with disability $e$ the promotion of community participation [dissertation]. São Paulo: University of São Paulo, Medical School; 2009.

This study was aimed at discussing the experience of implementing a co-existence group for adults with disabilities in the community as one of the territorial rehabilitation strategies, carried out by a Basic Health Unit. The goals were to: comprehend the process of group formation by adults with disabilities and identify the transformations that occur in both the individual and collective ambit; to understand the way of life and the demands of these people and assess how a co-existence group can help to address such demands. For the case study we used the semi-structured interview and a field diary to record the activities accompanied by the researcher. Ten adults with disabilities and who experience poverty and social isolation participated in the group, six of them women and four men. Among the adults surveyed, five have mental disabilities, three have physical disability and two have multiple disabilities. Interviews were conducted with five of the group participants, who represented the group in terms of age, sex and type of disability. The interviews dealt with issues such as daily activities, experiences in health and rehabilitation, education, work and community participation. 34 two-hour meetings were recorded, once a week, during 8 months, from March to December 2006. The undertaking of the group activity in the Community Center allowed the difficulties faced by people with disabilities to be seen by the community and led to the discussion of social rights issues. Through the interviews and observations, the lack of autonomy and initiative of people to participate in the activities of the group, as well as to discuss the situation of their daily life, became evident. These issues were addressed during the development of the group routine (participation in planning the activities, purchasing the material, manufacturing and sale). Participating in the group resulted in affective exchanges, the discovery of manual and creative skills, the sense of holding, improved self-esteem and improved communication amongst the participants. The organization of a peculiar way of life, focusing on the dimensions of living and eating (emergencies dealt with daily) was observed. For three of the interviewees the acquisition of a disability interrupted their productive life and their link to work. Other aspects of everyday life, such as dialoguing and going for walks, were important demands in the life of the interviewees. Studying, treatment in rehabilitation, having decent and comfortable housing, food, work, pension benefits, getting around, taking trips and talking were the main demands made by the subjects. The achievement of a co-existence group in the community was an experience of community participation, interpersonal exchanges and increasing network of social support for people with disabilities, which opposed the situation of social isolation. Coexistence groups can be an alternative assistance strategy for people with disabilities in the community.

Descriptors: 1.Disabled persons 2.Rehabilitation 3.Consumer participation 4.Occupational therapy 
1 INTRODUÇÃO 
As transformações sociais no campo dos direitos humanos têm provocado alterações nas alternativas para lidar com a deficiência e a reabilitação. Os princípios da caridade, do assistencialismo e as formas tradicionais de assistência têm sido questionados e novos modelos estão sendo propostos a partir do paradigma da inclusão social das pessoas com deficiência, compreendendo-as como sujeitos de direito.

Dentre as estratégias de intervenção em reabilitação no âmbito territorial, o presente estudo trata da implantação de um grupo de convivência na comunidade para adultos com deficiência que residem em bairro periférico da cidade e vivenciam situação de pobreza e isolamento domiciliar e que estão apartados das atividades comunitárias, culturais, educacionais, profissionais, e de cuidados à saúde e reabilitação. Temos como premissa que a situação de isolamento social é um fator de risco para essa população e consideramos importante desenvolver iniciativas que promovam a participação comunitária.

Este estudo tem como motivação contribuir para as práticas de Terapia Ocupacional no território a partir do detalhamento das ações e da reflexão sobre as estratégias de intervenção utilizadas.

São objetivos do estudo: compreender o processo de grupalização de adultos com deficiência (motivação, dificuldades enfrentadas, expectativas, recursos necessários, apoio recebido, entre outros) e identificar as transformações ocorridas no âmbito individual e coletivo (ampliação da rede de apoio social, melhoria das condições de sociabilidade, autonomia, cuidado pessoal, necessidade de apoio para realização de projetos pessoais, entre outras). Pretende-se também conhecer o modo de vida das pessoas com deficiência (como organizam o cotidiano, experiências de 
educação e trabalho antes e após a aquisição da deficiência, experiências em saúde e reabilitação, oportunidades de participação comunitária) e suas demandas, e como um grupo de convivência pode contribuir para responder a tais demandas e necessidades.

Schraiber e Mendes Gonçalves (1996), ao discutirem necessidades de saúde, definem demanda como uma busca ativa por intervenção. A procura é motivada pelo carecimento, algo que a pessoa compreenda que deve ser corrigido em seu atual estado sóciovital. Esse carecimento traz implicações para o cotidiano, sofrimentos e sentimento de falta.

Ainda segundo esses autores, a pessoa que sente determinada carência procura os meios para amenizá-la, a partir dos seus conhecimentos prévios sobre possíveis soluções. O resultado das intervenções sobre qualquer carência é reconhecido, portanto, como necessidade, tornando as próprias intervenções, também necessidades. A solução antevista é produzida e distribuída por algum serviço, que responderá às necessidades, mas também será um contexto de formação de necessidades. Para Schraiber e Mendes Gonçalves (1996), o problema está colocado quando é apenas uma parte restrita da população (gestores) que irá definir quais são as necessidades sociais (de todos) e quais serão as respostas oferecidas. Nesse processo, corre-se o risco de ignorar as desigualdades das necessidades sociais (carências criadas na vida em sociedade).

Cecílio (apud Pinheiro, Guizardi, Machado, Gomes, 2005) discute a complexidade do termo necessidade em saúde, que seria: "Uma potencialidade que ajudaria trabalhadores, equipes, serviços e redes de serviços a fazer a melhor escuta 
das pessoas, que buscam cuidado em saúde, tornando as necessidades centro de suas intervenções práticas” (p. 21).

Cecílio (2001) propôs uma classificação de necessidades de saúde, agrupada em quatro conjuntos de idéias:

$>$ necessidade de boas condições de vida;

$>$ garantia de acesso a tecnologia para manutenção e prolongamento da vida;

vinculação com profissionais e com equipe e

necessidade de exercer autonomia nas escolhas e decisões quanto ao modo de vida e de exercer o autocuidado.

Essa classificação das necessidades de saúde apresenta um conjunto de ideias pautado na determinação social, política e econômica do processo saúde-doença; no direito ao acesso a tecnologias que garantam a manutenção da vida, na importância da escuta e da fala nas relações interpessoais e institucionais, e na promoção do protagonismo e da autonomia das pessoas, através da democratização da informação e do estabelecimento de processos educativos. Portanto, a determinação das necessidades de saúde, a partir desta ideia, estaria focada no sujeito (Pinheiro, Guizardi, Machado, Gomes, 2005).

Essa forma de se pensar as necessidades de saúde tem norteado nossas reflexões acerca da produção de alternativas assistenciais em reabilitação com ênfase no território. Procuramos estabelecer um diálogo junto às pessoas com deficiência, suas famílias e a busca de recursos comunitários para que, coletivamente, sejam discutidas e produzidas ações que promovam oportunidades para lidar com as carências apresentadas pelas pessoas. 
Neste estudo, a participação comunitária foi compreendida a partir da definição de participação utilizada na Classificação Internacional de Funcionalidade, Incapacidade e Saúde - CIF (OMS, 2003), entendida como o envolvimento em uma situação de vida (p. 25). Essa definição traz a ideia de envolvimento, ou seja, "tomar parte, ser incluído ou participar em uma área da vida, ser aceito, ou ter acesso a recursos necessários” (p. 25). A CIF descreve as diversas ações e áreas da vida que fazem parte do que se chama de atividade (execução de uma tarefa ou ação por um indivíduo) e participação, sendo elas: aprendizagem e aplicação de conhecimentos; tarefas e demandas gerais, comunicação, mobilidade, cuidado pessoal, vida doméstica, interações e relacionamentos interpessoais e experiência comunitária, social e cívica.

Dada essa dimensão, nos afastamos, mas não completamente, da definição de participação comunitária apresentada pelos Descritores em Ciências da Saúde (DeCS), como sendo mecanismo através do qual a população, por meio de seus representantes, participa do processo de formulação de políticas de saúde e realiza controle social nas distintas esferas do governo. Em nossa pesquisa, nos deparamos com sujeitos muito distantes de seus direitos básicos de cidadania, o que nos fez abordar as ações e participações presentes no cotidiano, ainda relacionadas à manutenção da vida. Portanto, existe um longo caminho a ser percorrido para que essas pessoas realizem uma reflexão mais política sobre suas condições de vida e passem a questioná-las, tornando-se sujeitos de direitos. Tarefa árdua, mas não impossível, que tem norteado as ações deste estudo na tentativa de promover autonomia para sujeitos que tiveram reduzidas as oportunidades de vida. 
A argumentação do trabalho foi construída a partir da discussão sobre o tema da atenção à deficiência, suas principais problemáticas e as formas hegemônicas de assistência em reabilitação que predominam na atualidade. Apresenta-se o campo da Reabilitação Baseada na Comunidade como uma alternativa à reabilitação tradicional e as preocupações do Laboratório de Reabilitação com Ênfase no Território do Curso de Terapia Ocupacional da Universidade de São Paulo, que há oito anos atua no campo da reabilitação com base comunitária. Em seguida será apresentado o estudo do Grupo de Convivência Vida Nova, que inclui: breves considerações sobre o trabalho em grupos e oficinas terapêuticas na área de saúde, a construção da proposta assistencial, a apresentação dos participantes e suas motivações para participar, e o desenvolvimento do grupo propriamente dito.

Na sequência, abordaremos o tema das demandas das pessoas com deficiências a partir do estudo das atividades cotidianas e da compreensão dos modos de vida dos entrevistados.

Na última parte do texto, apresentamos uma discussão sobre as demandas relatadas pelas pessoas com deficiência e o desenvolvimento do grupo de convivência, procurando identificar que respostas essa alternativa assistencial pôde oferecer às demandas dessas pessoas. 


\subsection{Deficiência e reabilitação}

O conhecimento do perfil sociodemográfico das pessoas com deficiência mostra-se fundamental para discutir, no âmbito das políticas públicas e das iniciativas da sociedade civil, estratégias que promovam a inclusão das pessoas com deficiência nas diversas esferas da vida cotidiana, seja na escola, no trabalho, na saúde, na cultura, religião, habitação, no acesso à informação e no direito de ir e vir.

O trabalho de Neri (2003), denominado “Retratos da Deficiência no Brasil”, auxilia pesquisadores e estudiosos na discussão sobre a magnitude e relevância dos problemas da população com deficiência no país. $\mathrm{O}$ estudo revelou que aproximadamente $14,5 \%$ da população brasileira são pessoas com deficiência, num total de 24,5 milhões de pessoas, pois o Censo realizado no ano 2000 buscou conhecer o perfil das pessoas com deficiências, segundo tipos, graus de incapacidade e dados demográficos gerais. Assim, encontrou-se a seguinte distribuição: deficiência mental (11,5\%); tetraplegia, paraplegia ou hemiplegia $(0,44 \%)$; falta de um membro ou parte dele (5,32\%); alguma dificuldade para enxergar (57,16\%); alguma dificuldade para ouvir (19\%); alguma dificuldade para caminhar (22,7\%); grande dificuldade para enxergar (10,50\%); grande dificuldade para ouvir (4,27\%), grande dificuldade para caminhar (9,54\%); incapacidade de enxergar (0,6\%); incapacidade para ouvir (0,68\%) e incapacidade de caminhar (2,3\%).

O mesmo estudo indica a relação entre deficiência, pobreza e desigualdade social, destacando que $46 \%$ das pessoas com incapacidade (aproximadamente $2,5 \%$

\footnotetext{
${ }^{1}$ Organizado a partir da análise de estudos de diferentes organizações como o Instituto Brasileiro de Geografia e Estatística (IBGE) Censo demográfico de 2000, a Fundação Sistema Estadual de Análise de Dados (SEADE), o Ministério de Educação e Cultura (MEC), a Coordenadoria Nacional para Integração das Pessoas Portadora de Deficiência (CORDE) entre outros.
} 
da população brasileira) e 29\% das pessoas com deficiência vivenciam situação de pobreza. Neste panorama, 52\% das pessoas com deficiência são inativas, apesar de estarem em idade economicamente ativa, não exercem atividades produtivas e 42\% têm escolaridade inferior a um ano de estudo.

Em uma outra perspectiva, a falta de acesso aos serviços de saúde e reabilitação mostra-se como um dos principais problemas enfrentados pelas pessoas com deficiência, apontando para a fragilidade do Sistema de Saúde e a precariedade das condições de vida impostas à população de baixa renda.

Nesse sentido, desde 1993, tem-se discutido a iniciativa de implantar na rede do Sistema Único de Saúde a atenção integral à pessoa com deficiência, incluindo ações de prevenção, detecção precoce, diagnóstico, tratamento, reabilitação e integração social. Entre as estratégias previstas na proposta estavam o fomento a programas locais de atenção à saúde e reabilitação, o apoio às iniciativas de Reabilitação Baseada na Comunidade (RBC) articulada com demais níveis de complexidade do sistema de reabilitação e ao desenvolvimento de diagnósticos situacionais para caracterização de necessidades da clientela e da participação comunitária (Brasil, 1993).

Mais recentemente, em 2002, na Política Nacional de Saúde da Pessoa com Deficiência, embora não tenham sido delineadas propostas específicas para seu desenvolvimento, a RBC é apresentada como importante estratégia para ampliação da cobertura assistencial.

Almeida (2000) realizou um estudo crítico acerca dos Centros de Reabilitação, discutindo a prática dessas instituições centradas no modelo médicocientífico de abordagem das deficiências. Nesses serviços, não se prevê o 
protagonismo da pessoa com deficiência na discussão do projeto terapêutico, que é definido pela ação técnica a partir de parâmetros ideológicos e científicos. O paciente, após ser avaliado pela equipe técnica, é conduzido a programas com procedimentos padronizados, pouco flexíveis diante das necessidades singulares de cada sujeito. O uso de tecnologias de reabilitação específicas para avaliação e tratamento, embora importante para o aumento da sobrevida e diminuição das situações de incapacidade, parece superestimar a ação desses serviços, reafirmando a ideia de que somente em serviços especializados é possível realizar reabilitação com qualidade.

Por outro lado, esses serviços são localizados nas áreas centrais das grandes cidades, o que dificulta o acesso da maioria da população das áreas periféricas pelas dificuldades objetivas de deslocamento, como também têm baixa cobertura assistencial, frente à excessiva demanda gerada pelas condições de vida e saúde da população. Neste cenário, os serviços criam critérios de elegibilidade para ingresso em seus programas, que, na maior parte das vezes, privilegiam casos com bom prognóstico de recuperação, não sendo admitidos pacientes graves.

Embora existam críticas acerca dos princípios de organização e funcionamento dos Centros de Reabilitação, é reconhecida a importância desses serviços na composição da estrutura do sistema de atendimento às pessoas com deficiência, entendido como um direito para aqueles que necessitam de atendimento altamente especializado. Contudo, enfatiza-se a busca por alternativas no campo da reabilitação que estejam articuladas com necessidades e contextos socioculturais dessa população. Dentre essas possibilidades, destaca-se a Reabilitação Baseada na Comunidade, proposta de assistência em reabilitação preconizada pela Organização 
Mundial de Saúde (OMS) para ampliar a cobertura assistencial às pessoas com deficiência, envolvendo a atenção primária em saúde e os recursos da comunidade, e para fomentar a autonomia das pessoas com deficiência através do estabelecimento de intervenções mais democráticas e participativas integradas ao desenvolvimento comunitário e social (WHO, 2004).

Na literatura internacional sobre RBC, há diferentes pontos de vista e perspectivas sobre seu funcionamento, que destacam a singularidade das experiências no que diz respeito a protagonistas institucionais e comunitários, financiamento e articulação com políticas públicas. Há programas em diversas regiões: na América do Sul, descritos por Rojas et. al. (1999), Cieri (2005) e por Garcia (2005); na região do Pacífico, por Maneechak et. al. (2005), Tjandrakusuma (1998), Raj et al. (2004), Kuipers (2003) e Cheausuwantavee (2005). Também são encontrados programas na África do Sul, apresentados por Finkenflugel (2005) e Myezwa et al. (2003), e na América do Norte, por Neufeld (2005).

Os estudos apontam para a necessidade da construção da análise crítica sobre a estrutura organizacional da RBC e seus princípios, norteada por seguimento mais sistemático das experiências, a partir de indicadores que possam avaliar os programas e projetos desenvolvidos (Kuipers, 2003). Autores apontam as controvérsias e as dificuldades enfrentadas no que se refere: à participação comunitária como eixo dos programas de reabilitação baseada na comunidade, existindo diferentes níveis de engajamento da comunidade (Thomas; Thomas, 1998; Myezwa et al., 2003; Wee, 2004); falta de investimento na capacitação dos trabalhadores do primeiro nível da RBC (voluntários, familiares) e a ausência de protagonismo destes atores nos níveis de decisão e planejamento da RBC 
(Finkenflugel, 2005; Cheausuwantavee, 2005); crítica a não remuneração da força de trabalho da RBC e discussões acerca do perfil do voluntariado (Sharma et al., 2003; Brinkmann, 2004); sustentabilidade dos projetos de RBC (Thomas; Thomas, 1998; Tjandrakusuma, 1998) e crítica ao aumento da cobertura assistencial às pessoas com deficiência a baixo custo (Thomas M; Thomas MJ, 1998). Nesse sentido, percebe-se a necessidade de produção de conhecimento, técnicas e estratégias tanto para o desenvolvimento das práticas de RBC, como para constituir sua fundamentação teórica (Kronemberg et al., 2005; Hunt, 2005; Bury, 2005).

No Brasil, dentre os trabalhos existentes, destaca-se o de Almeida (2000) que aborda a assistência voltada às pessoas com deficiência, analisando os modelos assistenciais desenvolvidos tanto nos Centros de Reabilitação, como em alternativas como a RBC. Bodstein et al. (2003) relatam a experiência do Programa de Reabilitação Comunitária, realizada pela Secretaria de Assistência Social do Rio de Janeiro, no que diz respeito a população atendida, tipo de intervenções realizadas e recursos comunitários utilizados.

Temas como a construção de estratégias comunitárias e territoriais na assistência às pessoas com deficiência, a discussão sobre participação comunitária como princípio do trabalho e relatos singulares de experiências ocorridas em diferentes contextos socioculturais foram desenvolvidos por Oliver et al. (1999, 2001, 2002, 2003, 2004) a partir das experiências do Laboratório de Reabilitação com Ênfase no Território - Curso de Terapia Ocupacional da USP, que desde 1998 vem desenvolvendo atividades no âmbito da pesquisa, ensino e extensão em práticas comunitárias de reabilitação. 
Como nos princípios da RBC, os projetos são desenvolvidos em regiões geograficamente delimitadas, para compreender o contexto histórico, social e cultural da região, bem como a representação social sobre as pessoas com deficiência na comunidade. Inicialmente são levantados os recursos comunitários existentes e os atores sociais que podem contribuir para o desenvolvimento de atividades comunitárias. As pessoas com deficiência são identificadas, caracterizadas e suas demandas são discutidas coletivamente para a construção de uma proposta de atenção em sintonia com as necessidades expostas e os recursos comunitários existentes.

Desde 2001, o trabalho assistencial vem sendo desenvolvido através da parceria entre Curso de Terapia Ocupacional - FMUSP e profissionais da Unidade Básica de Saúde do Jardim Boa Vista, da Secretaria Municipal da Saúde, que atende a uma população estimada em 18 mil habitantes. Neste serviço foi implantado o Programa de Saúde da Família - PSF, sendo o Projeto de Reabilitação com Ênfase no Território referência para as questões voltadas às pessoas com deficiência da área de abrangência. As atividades assistenciais são realizadas por uma equipe composta por dois terapeutas ocupacionais (um profissional da Secretaria Municipal da Saúde e outro do Curso de Terapia Ocupacional da USP - proponente desta pesquisa), um coordenador (docente do curso de terapia ocupacional), e estudantes do Curso de Terapia Ocupacional da FMUSP. Na perspectiva da construção de um trabalho interdisciplinar, a equipe busca apoio junto a outros profissionais da Unidade, com destaque para o envolvimento do Agente Comunitário de Saúde, figura essencial no Programa de Saúde da Família, responsável pela interlocução entre comunidade e unidade de saúde. 
As estratégias utilizadas pelo Laboratório no acompanhamento das pessoas com deficiência no âmbito territorial são as seguintes: atendimentos e visitas domiciliares, discussão da inclusão de pessoas com deficiência nos equipamentos sociais, grupos de convivência e geração de renda com pessoas com deficiência, familiares e comunidade em geral, fóruns locais das pessoas com deficiência discussão acerca dos problemas enfrentados pelas pessoas com deficiência e possíveis soluções e encaminhamentos para acesso a direitos e informações, bem como a realização de passeios, atividades culturais e de lazer. Também são desenvolvidas atividades para a comunidade em geral como grupos de abordagem corporal para adultos, grupos de jovens e oficinas de brincadeiras para crianças abertos à participação das pessoas com deficiência.

Os resultados positivos do trabalho incentivaram profissionais a ampliarem as experiências para outras áreas de abrangência da unidade, que se localizam em regiões mais afastadas e empobrecidas do núcleo próximo à sede da unidade básica de saúde, como é o bairro Cohab Raposo Tavares, como também a delinear projetos de pesquisa e investigação sobre o desenvolvimento das atividades assistenciais em curso. 


\section{PROCEDIMENTOS METODOLÓGICOS}


A investigação insere-se no campo das pesquisas qualitativas por se tratar da reflexão e do desenvolvimento de um projeto assistencial a partir da compreensão da complexidade das condições de vida de um grupo de pessoas, inserido num determinado contexto sociocultural:

Por trabalhar em nível de intensidade das relações sociais, a abordagem qualitativa só pode ser empregada para compreensão de fenômenos específicos e delimitáveis mais pelo seu grau de complexidade interna do que pela sua expressão quantitativa (Minayo, 1993, p.245).

Neste estudo, a realidade foi compartilhada entre o pesquisador e os sujeitos pesquisados, todos atores importantes do cenário da investigação. Assim, no campo das ciências humanas, subjetividade e simbolismo são aspectos presentes no estudo e justificam a abordagem qualitativa.

Temos acompanhado sistematicamente as pessoas com deficiência do bairro Cohab Raposo Tavares desde 2005, quando teve início o trabalho de identificação e caracterização dessa população através de visitas domiciliares e entrevistas. Este trabalho foi apoiado pelos agentes comunitários de saúde e terapeuta ocupacional da Unidade Básica de Saúde do Jardim Boa Vista, que indicaram as famílias que apresentavam algum morador com deficiência. Também foram mapeados e visitados os principais recursos do bairro (centro comunitário, creches, escola municipal de ensino infantil e fundamental e igreja evangélica) e contatos foram realizados com líderes comunitários para compreensão da história do bairro na perspectiva de seus moradores. A partir dessa experiência, temos frequentado o bairro duas vezes por semana, dando continuidade ao trabalho de identificação das pessoas com deficiência, ao acompanhamento de algumas delas em atendimentos domiciliares, ou 
em sua inserção em equipamentos sociais e ao acompanhamento do Grupo de Convivência Vida Nova.

Assim, o cenário da pesquisa tem sido conhecido paulatinamente e de modo intenso, o que tem permitido um contato mais estreito com os sujeitos envolvidos na pesquisa e com seus modos de vida. O papel de terapeuta e pesquisadora permeou as reflexões e considerações do estudo. A preocupação foi identificar uma metodologia de pesquisa que contemplasse a compreensão do processo de grupalização das pessoas com deficiência e os diferentes aspectos dessa experiência: quem participou, qual a motivação para participar, como se deram as relações interpessoais, que aquisições e dificuldades foram percebidas, qual a implicação do pesquisador enquanto terapeuta do grupo, entre outros. Para tanto, adotamos o estudo de caso para compreender as características desta experiência.

Yin (2005) apresenta os estudos de caso como uma estratégia de pesquisa que pode responder a questionamentos do tipo “como” e "por que”, em situações nas quais o pesquisador tem reduzido controle sobre os acontecimentos e quando o objeto de estudo é um fenômeno contemporâneo, que ocorre num certo contexto da vida real. Neste caso, pretende-se analisar determinada unidade profundamente, compreendendo sua natureza e abrangência, articulando-a com os suportes teóricos que orientam o investigador (Triviños, 1987).

Os principais questionamentos colocados a este tipo de investigação estão relacionados à falta de rigor cientifico e à formulação de generalizações a partir do estudo de um caso único. Yin (2005) discute que diferentes fontes de evidência podem ser adotadas num estudo de caso, dentre elas a pesquisa documental, dados quantitativos, entrevistas e observações. Essas fontes são complementares e devem 
seguir linhas convergentes de investigação, o que torna o estudo mais criterioso e convincente. Quanto à formulação de generalizações no estudo de caso, o pesquisador aproveita as evidências empíricas e as inferências produzidas, correlacionado-as para alcançar a interpretação dos fatos, dentro de um sistema explicativo mais amplo (Diniz, in Martinelli, 1999). Para esta autora, a escolha do método, a decisão sobre o aporte teórico adotado e a explicação dos fenômenos investigados devem produzir enunciados universais, que dão significado à singularidade do estudo de caso. Procura-se evidenciar a relação entre o singular e o universal na explicação do fenômeno estudado.

Yin (2005) discute que ser pesquisador em estudo de caso não é tarefa fácil, sendo esperadas habilidades como: ter uma postura indagadora e criar boas hipóteses durante a pesquisa; ser um bom observador e ouvinte; ser flexível aos rumos do estudo, sabendo que eles podem não ser os mesmos delineados no projeto da pesquisa; ter clareza quanto ao propósito da investigação, realizar a coleta de dados já com a intenção interpretativa e estar atento às ideias pré-concebidas.

Considerando estas questões e a posição da pesquisadora enquanto coordenadora do Grupo de Convivência Vida Nova, foi necessário o estabelecimento de uma rotina e um fluxo de registros e reflexão que favorecesse o conhecimento da complexidade da experiência em curso. 


\subsection{Procedimento de coleta de dados}

A partir da estratégia do estudo de caso, a pesquisa utilizou a entrevista semiestruturada e o registro/diário de campo das atividades realizadas e acompanhadas pela pesquisadora enquanto terapeuta do grupo e interlocutora com a comunidade.

Como toda prática de investigação, o que se estuda é uma situação social permeada por processos comunicativos configurados por um conjunto de normas. Assim, ser pessoa com deficiência e participar de um grupo de convivência comunitário é um cenário específico, sobre o qual ocorrem processos comunicativos também específicos, que podem ser conhecidos através de estratégias de pesquisa, no caso, aquelas da pesquisa qualitativa (Galhego, 2002). Assim, a entrevista semiestruturada foi utilizada como técnica para abordar pessoas com deficiência e seus familiares, sujeitos que, de maneira geral, não possuem a experiência do relato oral, sendo algumas delas pessoas com deficiência mental. A condução da entrevista por parte do investigador pode oferecer às pessoas entrevistadas as perspectivas possíveis para que falem com liberdade e espontaneidade, tornando mais rica a investigação (Triviños, 1987).

O registro das atividades acompanhadas pela pesquisadora (participação no grupo de convivência, visitas domiciliares, participação em reuniões de equipes de saúde, demais encontros com moradores da comunidade) foi sistematizado a partir de dois aspectos fundamentais: a amostragem de tempo e as anotações de campo (Triviños, 1987). Os registros foram realizados durante oito meses, de março a dezembro de 2006, num total de 34 encontros, uma vez por semana, durante cerca de 
duas horas (tempo de duração de um encontro) no momento seguinte ao término do grupo e na ausência dos participantes. Para Triviños (1987), as anotações de campo consistem em descrições por escrito de diversas manifestações verbais, atitudes e ações que o pesquisador considera no fenômeno social. Considera-se também o contexto físico e o registro das reflexões do pesquisador diante das situações observadas e vivenciadas, que podem estar relacionadas também às questões metodológicas e teóricas. Todas essas informações e indagações representam as primeiras buscas de expressões e seus significados.

O diário de campo, como orienta Galhego (2002), tem a função de registrar o que é significativo entre o que é observado, fora da presença dos participantes, ou seja, é um exercício de observação e recordação. Propõe-se que o registro seja o mais amplo possível, e que a anotação seja minuciosa e que registre inclusive afetos, sentimentos e outras percepções do pesquisador, projetando o investigador nas notas que, por sua vez, se projetam no pesquisador, retroalimentando o processo de pesquisa e reflexão.

A compreensão do cotidiano dos adultos com deficiência (entre 18 e 60 anos) e suas demandas, bem como a disponibilidade e perspectiva em participar de um grupo de convivência, foi realizada através de entrevista semiestruturada. Essa entrevista foi guiada por roteiro (Anexo I), que abordou assuntos referentes à situação de saúde, experiências em reabilitação, educação e trabalho (antes e após a aquisição da deficiência), situação econômica, atividades realizadas no cotidiano, como lazer, cultura, religião, condição de locomoção, apoio social e a experiência de participar de um grupo de convivência. Também foram consultados os prontuários dos usuários da Unidade Básica de Saúde, bem como prontuários específicos do setor 
de Terapia Ocupacional deste serviço, que continham informações acerca das intervenções em saúde e em reabilitação já realizadas.

Os entrevistados, em número de cinco, foram escolhidos a partir de critérios de representatividade dentre aqueles que frequentam o grupo de convivência, sendo considerado o tipo de deficiência, idade e sexo. No total, participaram do grupo de convivência dez adultos com deficiência ${ }^{2}$ entre 18 e 60 anos de idade. Destes, seis eram mulheres e quatro, homens. Dentre os tipos de deficiência, cinco sujeitos apresentavam deficiência intelectual; três, deficiências físicas; e dois, deficiências múltiplas. Deste grupo, quatro pessoas foram escolhidas para a entrevista, sendo a quinta pessoa com deficiência entrevistada, selecionada dentre aquelas que não aceitaram participar do grupo de convivência.

As entrevistas semiestruturadas foram realizadas com a pessoa com deficiência e um familiar. Este foi incentivado a falar sobre suas percepções acerca da pessoa com deficiência, sobre o papel de ser cuidador, e cabia a ele fornecer informações complementares e esclarecimentos necessários sobre aspectos da vida dos entrevistados.

Existem poucos registros de pesquisas envolvendo entrevistas com pessoas com deficiência intelectual (Melleti, in Marquezine, 2003). Entrevistar pessoas com esse tipo de deficiência, oferecendo-lhes a oportunidade de falar sobre si, sobre seus anseios e desejos, foi um dos desafios deste estudo. O uso de um roteiro de entrevista, bem como a adoção de linguagem simples, de exemplos concretos e diretos e a repetição daquilo que pesquisadora ouvia (no caso de dúvidas quanto ao conteúdo que o interlocutor desejava comunicar), foram estratégias utilizadas no

\footnotetext{
${ }^{2}$ Também participaram do grupo duas adolescentes com deficiência mental com idade inferior a 18 anos, uma senhora idosa com deficiência auditiva, três pessoas com sofrimento mental, três pessoas da comunidade sem deficiência e duas voluntárias, somando um total de 21 participantes ao longo da experiência.
} 
momento das entrevistas. Todos os entrevistados, em diferentes graus, apresentaram dificuldades na expressão oral, sendo a narrativa, simplificada, descontinua e às vezes confusa no que se refere a cronologia e clareza quanto ao fato relatado. Contudo, o vínculo, anteriormente estabelecido no âmbito da assistência entre a pesquisadora e os entrevistados possibilitou que as narrativas fluíssem de modo satisfatório, oferecendo valiosas informações. As entrevistas foram realizadas após o período de registro da participação do sujeito no grupo de convivência, a fim de que os participantes pudessem falar e refletir sobre essa experiência.

Para compreender o processo de grupalização e participação das pessoas com deficiências no grupo de convivência foi realizado registro, a partir da organização de diário de campo produzido pelo pesquisador, com descrições e reflexões detalhadas sobre: os participantes presentes, a organização do ambiente, o desenvolvimento das atividades propostas, os comportamentos dos sujeitos, as linguagens utilizadas, os relacionamentos interpessoais e demais observações e reflexões pertinentes. Essa observação foi orientada por um roteiro de observação (Anexo II), construído a partir de orientações de Víctora et al. (2000).

O diário de campo também contou com descrições e reflexões da experiência de pesquisadora no contato com o território, as conversas com lideranças comunitárias e demais moradores, as observações realizadas nas visitas domiciliares, o que subsidiou a compreensão da história e da dinâmica deste bairro.

As pessoas entrevistadas e demais participantes do Grupo de Convivência foram informadas sobre o estudo, sendo apresentado o termo de consentimento informado a partir das orientações do Comitê de Ética em Pesquisa da Secretaria Municipal da Saúde - CEP/SMS e da Comissão de Ética para Análise de Projetos do 
Hospital das Clínicas da Faculdade de Medicina da Universidade de São Paulo CAPPesq, instituições que aprovaram a realização desta pesquisa (Parecer n ${ }^{0}$ 107/07 - CEP/SMS CAAE: 0012.0.162.000-07 e protocolo de pesquisa $\mathrm{n}^{0}$ 847/07 CAPPesq).

\subsection{Procedimentos de análise dos dados}

A etapa de análise dos dados das entrevistas foi apoiada pelas orientações de Bardin (1977). As entrevistas foram transcritas e examinadas exaustivamente (através de sua leitura e do acompanhamento do áudio). Foi realizada uma revisão cronológica (May, 2004) de cada relato, organizando eventos e situações vivenciadas numa linha do tempo, que auxiliou na compreensão do material e na identificação de lacunas que poderiam ser preenchidas numa segunda entrevista ou no contato com o familiar. Nesta fase de pré-análise, o material foi organizado a partir de temas e subtemas $^{3}$, da forma o mais abrangente possível, de modo que todas as questões pudessem ser incluídas (Gaskel, 2007).

Na fase de exploração, os dados foram recortados, agregados e categorizados a fim de se obter uma representação do conteúdo. Foram utilizadas unidades de registro (palavra, tema, personagem, acontecimentos, resposta a uma questão aberta da entrevista) e unidades de contexto que auxiliaram na compreensão das unidades de registro a partir de um contexto físico, social, político, cultural e ideológico do produtor da mensagem. Neste momento, foi construída, a partir da leitura mais

\footnotetext{
${ }^{3}$ Os temas selecionados nesta etapa de pré análise foram: história da infância e juventude (onde nasceu, que lembranças possui destas etapas da vida, relações sociais estabelecidas); composição familiar, situação de saúde e histórico de reabilitação antes e depois da aquisição da deficiência; experiência de educação e trabalho antes e após a deficiência, organização do cotidiano, saídas e passeios, vida econômica e como foi a participação no grupo de convivência.
} 
cuidadosa dos dados, uma grelha de análise ${ }^{4}$ para facilitar a organização e visualização dos dados e a procura do que Gaskel e Bauer (2007) denominaram de padrão de dados, isto é, a forma tanto da variabilidade (diferenças entre as narrações), quanto de consistência. Ainda pautadas nesses autores, foram identificadas as funções do discurso, sendo criadas hipóteses que foram testadas a partir dos dados da entrevista (como por exemplo: para o adulto com deficiência, a questão do trabalho seria um tema central? Ou, as pessoas com deficiências entrevistadas vivem uma situação de isolamento social?). Assim, a partir de uma visualização mais panorâmica dos dados, foi possível identificar os temas mais explorados, os assuntos recorrentes, as singularidades e situações sociais mais gerais, que foram o foco das inferências e interpretações.

A interpretação foi realizada a partir da contextualização do sujeito que fala, explicando a posição do entrevistado em termos de sua condição social e econômica, raça, gênero e posição ocupacional, não se centrando apenas no discurso (May, 2004).

O tratamento dos resultados e as interpretações ${ }^{5}$ ocorreram através das inferências, a partir de uma postura crítica e investigativa do pesquisador, à luz de uma discussão fundamentada nos princípios da participação comunitária, do acesso aos direitos e da construção de redes sociais de apoio às pessoas com deficiência.

A análise dos dados obtidos através dos registros em diário de campo referente ao grupo de convivência, as visitas domiciliares e demais situações relacionadas à experiência comunitária foi realizada basicamente através dos mesmos

\footnotetext{
${ }^{4}$ Na etapa da exploração do material, os dados foram organizados a partir dos temas mais explorados: a experiência da aquisição da deficiência a partir do sujeito, as experiências de trabalho, a organização do cotidiano (autonomia e independência para realizar atividades do dia a dia), isolamento domiciliar, convívio social, experiência de participar de um grupo de convivência, desejos e expectativas quanto ao futuro.

${ }^{5} \mathrm{Na}$ fase interpretativa, os temas abordados foram: a vida cotidiana, as demandas, o isolamento domiciliar e a participação no grupo de convivência Vida Nova.
} 
critérios descritos para a análise de conteúdo das entrevistas. Nas duas primeiras etapas de análise do grupo de convivência foram abordados os seguintes temas e subtemas: frequência, caracterização dos participantes, caracterização do grupo a partir dos sujeitos assistidos, motivações para participar, falta de autonomia e independência dos sujeitos, analfabetismo, estratégias para produção de autonomia e independência, relações interpessoais (como, com quem, qual o conteúdo e freqüência). Considerou-se também o enquadre do grupo (local, horário, atividades realizadas sistematicamente), a realização de passeios e saídas do bairro, a relação dos sujeitos com a atividade e o papel do coordenador.

$\mathrm{Na}$ fase de interpretação dos dados, foram analisados os temas mais recorrentes e relevantes da experiência do grupo, sendo eles: a caracterização dos sujeitos e suas motivações, o grupo como um lugar de promoção de aprendizagem, cuidado e transformações pessoais, as relações interpessoais, os passeios, a relação com a atividade e o papel do coordenador. Cabe relatar que todos os nomes citados na pesquisa são fictícios. 
3 COMPREENDER O CONTEXTO: O BAIRRO COHAB RAPOSO TAVARES 
O cenário para o desenvolvimento do Grupo de Convivência Vida Nova foi o bairro Cohab Raposo Tavares, localizado no quilômetro 19 da Rodovia Raposo Tavares, periferia da Zona Oeste da cidade de São Paulo e faz divisa com a cidade de Osasco. Foi criado em 1990, com a construção de prédios destinados aos mutuários inscritos no programa de habitação da Cohab $^{6}$. Segundo algumas lideranças, nesse mesmo período, a prefeitura de São Paulo destinou para este conjunto habitacional desabrigados de um desabamento na favela Nova República (bairro do Morumbi, região sudoeste da cidade), e outros da favela Juscelino Kubitschek (região sul) cujas habitações foram desapropriadas para construção da avenida com o mesmo nome. Estes moradores foram encaminhados ao Conjunto Habitacional Raposo Tavares para aproximadamente 422 "casas embrião" 7 , localizadas ao lado dos prédios do mesmo conjunto.

Os primeiros moradores enfrentaram problemas quanto à falta de infraestrutura básica, como precariedade no fornecimento de luz e água encanada, ausência de asfalto e equipamentos sociais. Diante das diversas demandas, a população priorizou a reivindicação, junto ao poder público, da construção de uma passarela na Rodovia Raposo Tavares para facilitar o acesso dos moradores a outras localidades. Também foi prioridade a construção, em 1992, de uma escola provisória no terreno da Igreja Católica (as chamadas “salas de aula de lata”), substituída, anos depois, por edificação de alvenaria em outro local do bairro.

\footnotetext{
${ }^{6}$ Companhia Metropolitana de Habitação de São Paulo (COHAB) é um dos principais instrumentos de execução da política de habitação da cidade de São Paulo. A missão da Cohab é garantir acesso à moradia para a população de menor renda, desenvolvendo programas habitacionais [citado em 1 mar. 2007]. Disponível em: http://www6.prefeitura.sp.gov.br/empresas ${ }^{7}$ idem
} 
Dados do Sistema de Informação da Atenção Básica - SIAB ${ }^{8}$ revelam que existem 2.915 habitantes que residem em 1.152 apartamentos. Cada prédio possui quatro andares e existem quatro unidades habitacionais por andar. Os apartamentos possuem aproximadamente $42 \mathrm{~m}^{2}$. Cada prédio tem entradas controladas pelos próprios moradores, conferindo um ambiente restrito e isolado, com poucas pessoas circulando nas áreas comuns.

Existem também as casas populares, onde residem aproximadamente 815 famílias, somando um total de aproximadamente 2.885 habitantes, segundo o SIAB (2008). As casas são todas de alvenaria, com construções prolongadas (horizontal e verticalmente), o que permite que mais de uma família possa morar em um mesmo quintal.

A circulação de pessoas com mobilidade reduzida está, em parte, facilitada pelas ruas planas do bairro. Porém, a presença de obstáculos nas calçadas e a falta de guias rebaixadas dificultam a circulação de pessoas em cadeira de rodas. Tanto nas casas quanto nos apartamentos (principalmente para aqueles que vivem a partir do primeiro andar) o acesso está dificultado pela dimensão reduzida das habitações, bem como pela presença de escadas e degraus.

As ruas onde estão localizadas as casas estão sempre movimentadas. Existem crianças brincando neste espaço, além de um grande número de jovens conversando nas esquinas e nos bares, o que poderia ser sinal de pouca oportunidade e desemprego. A presença de estabelecimentos comerciais de todo tipo (minimercados, padarias, quitandas, cabeleireiros, entre outros) indica o investimento no comércio local como consequência do aumento populacional e da situação de maior fixação

\footnotetext{
${ }^{8}$ Sistema de Informações de Atenção Básica - SIAB, Unidade Básica de Saúde Jd. Boa Vista, relatório consolidado, 2008.
} 
das famílias nessa região. Observamos também a existência de diversas igrejas evangélicas, que assim como a igreja católica local, são referências importantes para os moradores do bairro.

O bairro conta com duas escolas de ensino fundamental (uma municipal e outra estadual), uma escola de educação infantil, duas creches, um centro comunitário e a Unidade Básica de Saúde/Programa de Saúde da Família Jardim Boa Vista. Estes equipamentos assistenciais também são utilizados por bairro vizinho, denominado VILA MUNCK, com aproximadamente de 1.707 habitantes. Serviços como as creches, a escola de educação fundamental municipal e a Unidade Básica de Saúde já possuem demanda reprimida.

O bairro Cohab Raposo Tavares completa sua "maioridade", com uma história muito rica, de enfrentamento das necessidades, conflitos, reivindicações e conquistas.

Os desafios são muitos e renovam-se a cada momento. O nosso olhar de “estrangeiro”, carregado de valores culturais e sociais, aquietou-se diante da possibilidade de compreender a história do lugar, marcada por lutas e participação. Para Wong Un (2002), em sua tese sobre visões de comunidade na saúde, existe uma mudança conceitual na abordagem da construção comunitária, uma alteração no foco de atenção, da carência à potencialidade, buscando-se reconhecer as capacidades e as potencialidades das pessoas e da comunidade. Questiona-se a relação, muitas vezes presente no pensamento dos profissionais, entre comunidade pobre e carência, esquecendo-se da lógica da intensidade, presente na vida dos sujeitos como afirmação da vida. Intensidade, compreendida como: "lógica da curtição e do 
aproveitamento do tempo de formas distintas àquelas que os técnicos e intelectuais consideram as mais corretas” (Wong Un, 2002, p. 70).

A história de mobilização esteve presente também no âmbito das pessoas com deficiência e foi resgatada neste estudo. Em 2001, pessoas com deficiência moradoras da região, familiares, profissionais da saúde, representantes do poder público ligados ao setor da saúde e transporte e representantes do Conselho Municipal da Pessoa com Deficiência da cidade de São Paulo se reuniram para discutir os problemas enfrentados por esta população e reivindicar providências junto ao setor público. Nesse encontro, um dos assuntos mais discutidos foi a dificuldade de locomoção das pessoas com deficiência e o acesso a serviços de saúde, reabilitação e educação. A reunião possibilitou que profissionais do Laboratório de Reabilitação com Ênfase no Território pudessem conhecer algumas das pessoas com deficiência do bairro e que, num outro momento, pudessem retomar os contatos para elaborar projetos assistenciais.

Dentre os participantes, destacou-se a presença de uma mãe de jovem com deficiência que se empenhou na reivindicação da inclusão de sua filha em escola regular do bairro. Nessa época, esta liderança desejou criar uma associação de pessoas com deficiência no Centro Comunitário Raposo Tavares e realizou um primeiro levantamento das pessoas com deficiência do bairro. Porém a falta de estrutura física do local não possibilitou a instalação da associação. Essa moradora é uma referência para assuntos sobre deficiência na região e, em 2005, foi eleita presidente do Conselho Municipal da Pessoa com Deficiência, expandindo suas atividades para toda a cidade. Seu trabalho de identificação das pessoas com 
deficiência no bairro serviu como ponto de partida para que, em 2005, retomássemos o cadastramento dessa população.

Desde 2001, a terapeuta ocupacional da Unidade Básica de Saúde já desenvolvia um trabalho comunitário com a organização de um grupo de mobilização corporal (tai chi) para a comunidade em geral e atendimentos das pessoas com deficiência na unidade. Portanto, antes de nos aproximarmos mais sistematicamente dessa população, já existia um conhecimento prévio e geral do bairro e uma sensibilização da comunidade para o trabalho com a população com deficiência.

No segundo semestre de 2005, foi realizada uma pesquisa de levantamento e caracterização das pessoas com deficiência moradoras do bairro Cohab Raposo Tavares. Com o apoio de agentes comunitários de saúde, que indicaram as pessoas com deficiência moradoras de suas microáreas de atuação, terapeuta ocupacional e estudantes do curso de Terapia Ocupacional (TO) da USP realizaram entrevistas domiciliares para sua caracterização. No total, 53 pessoas com deficiências (motoras, intelectuais, visuais, auditivas e múltiplas) foram identificadas e 48, entrevistadas. Destas, 9 eram crianças, 27 adultos e 12 idosos. Os adultos, foco desta dissertação, tiveram dificuldades para acessar serviços de saúde e reabilitação, apresentaram baixo grau de escolaridade, o que refletiu em suas experiências de trabalho, que exigiam pouca qualificação e muito desgaste físico. Grande parte das famílias depende de aposentadorias e benefícios públicos do sistema de seguridade social, principalmente o Benefício de Prestação Continuada $^{9}$ e muitas vivem situação de

\footnotetext{
9 O Benefício de Prestação Continuada garante um salário mínimo mensal a idosos com 67 anos ou mais e às pessoas com deficiências incapacitadas para o trabalho. O direito está reservado a indivíduos com renda familiar per capta inferior a um quarto do salário mínimo. Trata-se de um beneficio assistencial, já que não exige que o sujeito tenha contribuído com o setor previdenciário (Neri, 2003).
} 
pobreza. Observou-se a fragilidade da rede de apoio social da pessoa com deficiência (muitas vezes restrita à família nuclear, ou mesmo a um só cuidador) e o isolamento domiciliar esteve presente neste grupo.

Essas informações subsidiaram a formação de um grupo de convivência, pensado como alternativa para romper o isolamento de pessoas com deficiência, bem como para ser um espaço de cuidado e sensibilização acerca dos direitos sociais desta população. 
4 GRUPO DE CONVIVÊNCIA VIDA NOVA: UMA EXPERIÊNCIA DE PARTICIPAÇÃO COMUNITÁRIA 
A experiência com grupos de convivência para pessoas com deficiência na comunidade tem se desenvolvido a partir da prática, construída através da percepção de demandas apresentadas pelas pessoas com deficiência, articulada aos recursos locais comunitários. Desta forma, temos acumulado conhecimento e estratégias para abordagem territorial em reabilitação, associando o saber popular e o conhecimento técnico. O ineditismo deste trabalho, construído no cotidiano da prática pelos usuários, coordenadores, estudantes envolvidos e demais atores da comunidade, fez com que buscássemos um aporte teórico híbrido, a partir daquilo que já foi constituído no campo da terapia ocupacional, do trabalho assistencial em grupos no âmbito da saúde, das oficinas terapêuticas, da construção da participação comunitária e do acesso aos direitos sociais.

Embora grande parte do referencial teórico que será apresentado tenha sido construído no campo da saúde mental e parte, articulado à terapia ocupacional, acredita-se que tais saberes possam auxiliar na compreensão da organização de um grupo de convivência para pessoas com deficiência na comunidade, que se constitui como um lugar de encontro, aprendizado, cuidado e escuta.

Tínhamos como eixo orientador do trabalho a organização de um grupo de convivência, pautado no desenvolvimento das oficinas terapêuticas. Embora a leitura dos aspectos psicológicos dos participantes não fosse central nessa experiência, seu desenvolvimento (percepção que tivemos ao nos debruçar sobre as informações do diário de campo) nos fez refletir sobre a sua presença na dinâmica grupal estabelecida. Em qual dimensão aqueles aspectos estariam presentes e como influenciaram as relações interpessoais, o grupo como um todo e os sujeitos participantes? A leitura de trabalhos de terapeutas ocupacionais sobre grupos com 
uma abordagem subjetiva (Samea, 2002) também nos fez refletir sobre aspectos emocionais presentes na dinâmica de grupos e a interrogar algumas situações e fenômenos que fizeram parte de nossa experiência. Foram foco da nossa análise e discussão sobre o grupo de convivência questões referentes a: produção do espaço de encontro, os participantes (características individuais, expectativas quanto a participação, transformações pessoais e coletivas percebidas), o desenvolvimento da experiência, o papel do coordenador e de demais atores e os desafios colocados para a continuidade do trabalho.

\subsection{Breves considerações sobre o trabalho com grupos e oficinas terapêuticas}

Zimerman e Osorio (1997) sistematizaram, de um modo geral, quais seriam as características de um grupo e indicaram as condições mínimas para sua existência:

Não é a somatória de indivíduos, pelo contrário, constitui uma nova entidade.

Todos os integrantes estão reunidos em torno de uma $\operatorname{tarefa}^{\mathbf{1 0}}$ e de um objetivo e interesse comum.

O tamanho do grupo deve respeitar e preservar as capacidades de comunicação (falar e ser ouvido).

Dxistência de um enquadre (setting), normas e regras de interação (com o espaço, entre os sujeitos).

O grupo é uma totalidade e seus membros fazem parte dele.

\footnotetext{
${ }^{10}$ Pichon-Riviere (1991) trata a tarefa de acordo com o campo operativo do grupo. No caso de um grupo terapêutico, a tarefa é abordar a ansiedade do grupo. No caso de um grupo de aprendizagem, a tarefa consiste na resolução de ansiedades relacionadas a determinado campo operativo e na facilitação para assimilar uma informação. O propósito geral, segundo o autor, é o esclarecimento, em termos das ansiedades básicas, da aprendizagem, da comunicação, do esquema referencial, da semântica.
} 
$>$ O grupo possui identidade própria e genuína e preserva a identidade dos sujeitos que o compõe.

A Coesão e desintegração são tensões que coexistem no grupo.

A dinâmica grupal se processa em dois planos, a intencionalidade consciente e a interferência de fatores inconscientes.

$>$ A existência de uma interação afetiva entre os participantes apresenta-se sob diversas formas.

As atribuições hierárquicas de posições e papéis sociais estão presentes entre seus membros;

> A formação de um campo grupal dinâmico, no qual se desenvolvem sentimentos, ansiedades, mecanismos de defesa, fantasias, resistências, fenômenos transferenciais e contratransferenciais, além de outros fenômenos relacionados ao psiquismo (pulsões libidinais, agressivas, narcisísticas), possibilita manifestações sob forma de necessidades, desejos, demandas, inveja, entre outros.

Dentre os aspectos grupais citados, elencamos alguns que seriam importantes para a discussão do Grupo de Convivência Vida Nova, começando pela tarefa. Para muitos dos participantes, o objetivo do grupo de convivência é fazer bijuteria para vender (tarefa). É desta forma, concreta e simplificada, que compreendem a experiência de participação. Embora a convivência seja a principal questão colocada pelos coordenadores do grupo, a ação de "fazer algo" parece ser ressaltada pelos participantes, o que aproxima esta experiência grupal à ideia de um grupo de atividade (Maximino, 2001), um conjunto de pessoas reunidas que realiza atividades (artesanais, plásticas, gráficas entre outras), o que implica em ação e uso de 
materiais. Esta foi uma premissa deste projeto: para pessoas com deficiência, muitas delas com pouca autonomia, com possibilidades e experiências reduzidas no campo da linguagem e comunicação, realizar atividades concretas poderia ser uma forma mais fácil e prazerosa de entrar em contato com outras pessoas e se expressar. Talvez um grupo verbal, outra modalidade assistencial muito discutida pela literatura, não demonstrasse a mesma adesão que o grupo de atividades obteve, considerando as características da população atendida.

No contexto de grupo, a comunicação é fundamental para estabelecer objetivos, considerar opiniões diversas, identificar e lidar com situações conflitantes, sendo fundamental que o coordenador do grupo incentive os participantes a se comunicarem, o que aumenta o sentimento de pertinência no grupo (Mosey apud Maximino, 2001). Essa foi uma postura permanente dos coordenadores do grupo, atentos às diversas formas de expressão, não somente as verbais, mas também as fomas gestuais de comunicação, o tom de voz, o silêncio, o olhar, a forma de se apresentar e se vestir. Assim, pretende-se compreender como as pessoas se comunicaram no grupo, quais foram os conteúdos expressos e quem foram os interlocutores. O grupo facilitou a expressão dos sujeitos? Possibilitou o acesso à informação e promoveu algum grau de aprendizagem?

Os grupos são organizados a partir de um enquadre, o setting grupal, compreendido como a soma de todos os procedimentos que o organizam, suas regras e contratos acordados entre os participantes e que possibilitam o funcionamento grupal (Zimerman; Osorio, 1997; Ballarin, 2007). Esses contratos incluem o local, a periodicidade, o tempo de duração, horários, pagamentos (caso exista a modalidade de vendas de produtos produzidos), número de participantes, regras de convivência 
entre outras combinações. Embora essas regras de participação estejam presentes no Grupo de Convivência Vida Nova, não seria mais adequado falar em ambiente comunitário em vez de setting grupal? A experiência ocorre num centro comunitário, o grupo é aberto e heterogêneo. Familiares também podem participar do encontro. Quando consideramos necessário e conveniente, buscamos a pessoa com deficiência em seu domicílio. Diante de um cenário tão diversificado e intenso, composto por sujeitos que manifestam sentimentos, por exemplo, que vão desde a apatia, até a ansiedade, a atuação do coordenador mostra-se determinante, valendo-se de sua disposição afetiva e do emprego de estratégias para promover convivência, aprendizado e cuidado.

Um grupo coeso pode promover o aprendizado dos seus participantes. Maximino (2001) discutiu a coesão no grupo a partir das contribuições de Mosey, considerando que este é um fenômeno positivo, observado através do grau de proximidade entre os integrantes e o valor que o sujeito atribuiu ao grupo, considerando o quanto cada um sente-se atraído e aceito por ele. Por algum motivo este grupo é especial para os participantes e isso desencadeia a vontade de estar e fazer coisas juntos. Assim, a afetividade se torna um facilitador para que ocorra a aprendizagem e acreditamos que este foi um fator operante no grupo. O contrário da coesão pode ser observado nas faltas e ausências dos integrantes, algo que ocorreu logo nos primeiros encontros do Grupo de Convivência Vida Nova. Tal fato nos fez refletir sobre a motivação ou não dos sujeitos envolvidos, a sintonia entre proposta e as demandas, bem como a organização de estratégias para promover a participação daqueles que, de alguma forma, poderiam se beneficiar do grupo. 
Um aspecto importante a ser considerado na abordagem grupal é o papel social atribuído às pessoas com deficiência. Para Samea (2002), que cita a teoria pichoniana, os papéis são condutas que a pessoa exerce na sociedade, produzidas a partir da interação com outros sujeitos e contextos sociais determinados. Portanto é na relação social que os papéis são desempenhados, e, por isso eles não existem isoladamente. A assunção de um papel por um sujeito depende da atribuição do outro, numa relação de complementaridade. A mobilidade entre os papéis é que produz aprendizado no grupo, sendo a cristalização de papéis apresentada sob forma de repetições estereotipadas nas relações, foco de manejo do coordenador do grupo. Considera-se também que o sujeito pode reproduzir no grupo o mesmo papel que desempenha na família e em outros contextos sociais, indicando a cristalização de seu papel social. A partir dessas colocações, as pessoas desempenharam papéis no grupo estudado? Houve repercussões no que se refere às representações dos sujeitos na família e na comunidade a partir da participação num grupo de convivência?

Por fim, consideramos o estabelecimento de vínculos como fenômeno importante no desenvolvimento do estudo de grupos, sendo a base das relações interpessoais, do aprendizado e do cuidado gerado no grupo de convivência. Samea (2002) abordou a noção de vínculo, a partir das concepções psicanalíticas pichonianas. Vínculo que seria uma estrutura complexa, que inclui um sujeito, um objeto e sua mútua interrelação com processos de comunicação e aprendizagem. Esses vínculos são fundamentais para a constituição do sujeito. Zimerman e Osorio (1997) discutem o reconhecimento como forma de vínculo, no qual o sujeito necessita, de forma vital, ser reconhecido pelos integrantes do grupo (fenômeno da pertinência). 
A terapia ocupacional tem se utilizado de diversos campos de saberes para constituir e discutir práticas grupais, dentre as quais Maximino (2001) abordou:

a psicodinâmica, representada pelos autores Fidler e Fidler (1963), que consideram a importância de aprender a conviver com a nova situação grupal, conhecer os sujeitos que a compõe e compreender a proposta de estar junto com outros; consideram também que esta estrutura permite o aparecimento de diversos papéis sociais, muitas vezes reproduzindo o lugar ocupado pelo sujeito no contexto familiar;

a comportamental desenvolvimentista, apoiada por ideias de Jean Piaget, compreende o grupo como um lugar de aprendizado, utilizando-se de imitação e reforço; acredita-se que a manipulação do ambiente e as recompensas podem produzir transformações no comportamento. Esse tipo de abordagem tem sido utilizado na aquisição de habilidades profissionais, na promoção de independência, no enquadre nas normas sociais e treinamento de atividades realizadas no cotidiano. Como exemplo, pode-se citar os grupos educativos;

a psicanalítica, que utiliza o recurso da interpretação e compreende o grupo como o superego e reativador de ansiedades e conflitos. O contexto grupal promove relações interpessoais. A atividade neste contexto seria utilizada como meio mobilizador de acontecimentos e facilitador de projeções;

a abordagem de grupos operativos, de Pichon-Rivière, que utiliza os referenciais teóricos da psicanálise (dentre eles, a interpretação do coordenador do grupo como meio de tornar explícito o implícito no grupo) e do materialismo histórico (o homem é produto das determinações sociais); considera o processo terapêutico como um processo de aprendizagem que tem como meta fazer com que o 
sujeito “aprenda a pensar" e se permita a isso, desenvolvendo a capacidade de resolver dialeticamente situações conflitivas. Este aprender a pensar refere-se sempre ao campo grupal (Maximino, 2001, p. 79).

Existem ainda os grupos de autoajuda (Zimerman; Osorio, 1997), formados por sujeitos que enfrentam problemáticas semelhantes (no campo da saúde orgânica e/ou do psiquismo) que se sentem identificados e se unem, numa tentativa de se auxiliarem reciprocamente.

No Brasil, outros autores terapeutas ocupacionais têm se debruçado sobre o tema.

Sousa e Jorge (2000) relataram a experiência de um grupo de atividades em terapia ocupacional com jovens com deficiências intelectuais. A partir da teoria psicodinâmica e do conhecimento sobre o processo de realização de atividades, as autoras analisaram a produção do grupo, enfatizando os momentos das falhas (impossibilidades e paralisações demonstradas pelos jovens durante a realização das atividades) como sendo momentos de reversibilidade e reconstruções.

Kebbe (2002) realizou estudo de revisão de artigos científicos que abordaram o tema atividades em grupos terapêuticos realizados no campo da saúde (incluindo a terapia ocupacional) no Brasil, Europa e Estados Unidos, no período entre 19951998). Nos artigos analisados foram descritos grupos de atividades físicas, técnicas de relaxamento corporal e palestras como recursos terapêuticos empregados no tratamento de pessoas com incapacidades físicas e sofrimento mental, além de atividades lúdicas, utilizadas em educação e orientação em saúde. Nesse sentido, a atividade foi utilizada como recurso para estimular o processo grupal, a comunicação e a adesão à proposta terapêutica. Jogos, dramatizações, exercícios físicos e 
realização de trabalhos manuais também foram utilizados em grupos terapêuticos, o que facilitou a expressão e a comunicação dos sujeitos a partir da orientação do profissional e seu embasamento teórico (orientação psicodinâmica e cognitivo comportamental foram os mais citados).

Ballarin (2001) apresentou um estudo teórico-clínico sobre terapia ocupacional e a utilização de grupos de atividades em saúde mental. Para tanto, a autora entrevistou terapeutas ocupacionais que realizavam grupos em serviços de assistência em saúde mental. Dentre outros assuntos, discutidos pela autora, destacamos o tema referente ao papel do terapeuta coordenador, que possui as funções de planejar (preparar o setting), de facilitar (ser continente ao grupo, ser uma referência), ensinar (determinada técnica ou habilidade) e coordenar (ações relacionadas às possíveis intervenções que ele realiza no grupo, tendo como direção os seus objetivos). Considerando o referencial psicodinâmico, a autora enfatiza os fenômenos transferenciais e contratransferencias como elementos centrais da análise do grupo.

Na experiência do Grupo de Convivência Vida Nova existem algumas peculiaridades em relação ao papel do coordenador que devem ser consideradas: existiu a co-coordenação, partilhada entre dois terapeutas ocupacionais, que enriqueceu e apoiou a constituição do grupo. Além disso, a estrutura organizacional do grupo contou com o apoio de voluntários, agentes comunitários de saúde e estudantes de terapia ocupacional, o que determinava certo dinamismo ao grupo, por exemplo, com a mudança de estudantes semestralmente, o que implicava no estabelecimento do vínculo, sentimentos de perda e ansiedade dos participantes com relação ao novo (a chegada de novas estagiárias). 
Maximino (2001) realizou revisão bibliográfica sobre o histórico do uso de grupos na terapia ocupacional entre as décadas de 30 e meados dos anos 90 e apresentou a experiência de um grupo de pacientes adultos psicóticos, realizado em uma Unidade Básica de Saúde, a partir do referencial psicanalítico. Num primeiro momento observou-se um agrupamento de pessoas que esperava que o coordenador lhes dissesse o que fazer. Este assumiu um papel ativo na proposição das atividades, cuidou do setting grupal e o conduziu de modo que este se tornasse mais autônomo e que houvesse um ambiente mais propicio às trocas interpessoais. O lugar do terapeuta foi de referência, eixo de articulação e redistribuição do vínculo (que num primeiro momento era bastante dual, entre paciente e terapeuta), papel que pôde ser construído a partir do desejo do terapeuta pela constituição do grupo. O uso de materiais e atividades livres (plásticas e de artesanato) pôde ir ao de encontro das demandas e desejos dos pacientes e foi um facilitador do estabelecimento do vínculo entre os participantes, o que auxiliou na constituição do grupo. Para a autora, o grupo adquiriu autonomia e funcionou sem a dependência da intervenção da coordenadora.

Samea (2002), a partir dos referenciais teóricos de Pichon-Rivière, estudou um grupo de terapia ocupacional formado por pessoas com deficiências e com transtornos psíquicos que realizaram atividades artísticas e passeios, grupo desenvolvido na Estação Especial da Lapa, um centro de convivência público. O objetivo do trabalho foi observar um processo grupal no campo da reabilitação, atendo-se às questões subjetivas e o lugar social ocupado pelos integrantes. A experiência foi compreendida como possibilidade de os sujeitos construírem projetos de vida que levassem em conta os limites e as capacidades, no que se refere às condições física, psíquica, social e do contexto institucional. 
A experiência de Samea (2002) dialoga diretamente com situações e fenômenos vividos no Grupo de Convivência Vida Nova. Destacamos a discussão sobre a representação social da deficiência mental e o convívio destes sujeitos na comunidade, a falta de oportunidades de aprendizado, de suporte e investimento, tema que também está presente em nosso trabalho. Diferentemente de um projeto inserido numa instituição de reabilitação, como descrito e analisado pela autora, nosso trabalho ocorre no contexto comunitário, ideia defendida pela autora, como lugar privilegiado para criar e estabelecer redes, ligações e interlocuções, algo a ser inventado, porém que também apresenta seus limites e impasses, o que será discutido no presente trabalho.

No que se refere às oficinas terapêuticas, no contexto da Reforma Psiquiátrica, tem-se assistido nos últimos vinte anos, o desenvolvimento de práticas nas quais as atividades expressivas, criativas e produtivas, associadas a abordagens psicodinâmicas, estéticas e sociais, têm sido utilizadas no delineamento da organização de espaços substitutivos de cuidados em saúde mental (Lima, 2004). As oficinas terapêuticas podem ser compreendidas como uma das alternativas assistenciais que, segundo a autora, remetem à ideia de produção e desta para a ideia de produção de subjetividade. É nesses espaços que se engendram, se experimentam, se criam novas formas de relacionamento, novos espaços existenciais, novos modos de ser (Lima, 2004, p. 71).

Galleti (2004), em seu livro, Oficina em saúde menta”, discute que o tema tem sido pouco explorado no que se refere à sustentação teórica e científica, sendo ainda uma produção construída na prática. Para Guerra (2004), embora cada oficina 
seja única e as finalidades diversas, sua origem, teorização e análise são importantes para evitar uma prática ingênua e imprudente.

Nesse sentido, algumas reflexões teóricas sobre as oficinas, embora centradas no campo da saúde mental, poderão apoiar a discussão de alguns aspectos relacionados ao Grupo de Convivência Vida Nova.

Ribeiro (2004) discute as oficinas como dispositivos catalizadores de produção psíquica dos sujeitos envolvidos, facilitando a circulação social na família, na cultura, bem como sua inserção ou reinserção no trabalho produtivo. Guerra (in Costa e Figueiredo, 2004) enfatiza a ampliação da rede e da contratualidade social ${ }^{11}$ do usuário, respeitando suas singularidades. Para o autor, as oficinas são construídas a partir do chamado à participação e a produção na cultura e ajudam o sujeito a reestruturar o cotidiano e o trabalho. A essência das oficinas estaria na proposta de articular a dimensão sociopolítica com a subjetividade dos sujeitos envolvidos.

Botti (2004) considera que as oficinas operam como espaço terapêutico, a partir do momento que possibilitam aos participantes um lugar de fala, expressão e acolhimento. Também constitui um dispositivo ${ }^{12}$ de reintegração sociocultural, utilizando como estratégia atividades de expressão, produção, recreação e convivência. Nesse sentido, pode ser um espaço de produção de trabalho manual ou oficio, criação, distração e aprendizagem. Um lugar que acolhe as diferenças e as singularidades e que promove o cuidado, em oposição à ideia de tratamento da doença.

\footnotetext{
${ }^{11}$ A contratualidade tem sido abordada no campo da reabilitação psicossocial; discute-se que nas relações interpessoais, as trocas (de bens, afetos e mensagens) são realizadas a partir de um valor previamente atribuído à cada sujeito, como pré-condição para esse processo. A contratualidade estaria relacionada a este valor que, pressupostamente é atribuído ao sujeito (Kinoshita, 2001). O autor discute a invalidação do poder contratual do doente mental e podemos pensar na mesma discussão aplicada à condição da pessoa com deficiência, quando considerada doente e incapaz de realizar trocas sociais, opinar e refletir, com autonomia, sobre projetos singulares de vida.

${ }^{12}$ Conjunto de meios planejadamente dispostos com vista a um determinado fim (Ferreira, 1988).
} 
Gabbay (2004) também aborda o cuidado gerado nas oficinas, através de ações que visam à participação social. Nesse enfoque, desenvolvem-se projetos de trabalho e/ou atividades artísticas e artesanais. Para a autora, romper com o isolamento social é um dos principais objetivos das oficinas.

Em 2002, a Secretaria de Assistência Social à Saúde, através da Portaria no. 728 regulamentou os procedimentos de Oficinas Terapêuticas destinadas às pessoas com deficiência e transtornos mentais, que passaram a constar na Tabela do Sistema Único de Saúde. São duas modalidades, definidas como Oficina Terapêutica I e II, sendo a primeira de vertente focada na produção (com a presença de oficineiros com formação em nível médio) e a segunda de vertente terapêutica, com a presença de profissionais de nível superior. Segundo o documento, o atendimento em Oficina Terapêutica II, para pessoas portadoras de deficiência é definido como:

Atividade profissional em Grupo (no mínimo cinco e no máximo 10 pacientes) socialização, expressão e inserção social, com duração mínima de 2 (duas) horas, executada por profissional de nível superior, através de atividades profissionais como carpintaria, costura, cerâmica, artesanato, artes plásticas, entre outras. As oficinas terapêuticas poderão funcionar, não apenas na própria unidade, mas também em outros espaços específicos, desde que o profissional responsável pela execução do procedimento esteja lotado na unidade de saúde (...). A unidade deverá contar com uma equipe mínima composta por quatro profissionais de nível superior, sendo pelo menos um da área de reabilitação (Brasil, 2002).

A palavra "oficina” traz a ideia de um lugar onde se exerce um ofício (Ferreira, 1998) e está relacionada com atividades de geração de renda e experiências de cooperativas em saúde mental.

No campo da reabilitação, as atividades desenvolvidas nas oficinas estão relacionadas ao trabalho e à geração de renda, e têm como objetivo a participação do sujeito na comunidade. Galleti (2004) alerta para a proximidade entre as oficinas e o 
trabalho, enfatizando o cuidado para não se reproduzir a lógica do trabalho no modo de produção capitalista, que aliena, despersonaliza e exclui os não aptos ao sistema produtivo. Nesse sentido, o desafio é: “...a produção de sentido, isto é, trata-se de encontrar modos de produção que singularizem existências, permitam o surgimento de processos criativos e, fundamentalmente, que legitimem a pluralidade da vida” (Galletti, 2004, p. 38).

Diversas experiências de oficinas de geração de renda são apresentadas e debatidas na literatura em saúde mental (Costa e Figueiredo, 2004). Em relação às pessoas com deficiência não foi localizada literatura específica. O que se pode dizer é que o Grupo de Convivência Vida Nova, embora tenha se estruturado a partir da ideia de "fazer algo junto" e que derivou em atividades de venda das bijuterias confeccionadas, não se caracterizou como um grupo de geração de renda e, sim, de convivência comunitária, o que faz interface com as oficinas terapêuticas.

Nossa prática dialogou diretamente com a experiência denominada Oficina do Fazer, onde foram realizadas atividades de marcenaria, na comunidade, com a participação de pessoas com e sem deficiência e transtornos psíquicos. Constatou-se que as oficinas, organizadas a partir da demanda da geração de renda, tiveram como principal resultado a ampliação da rede social dos participantes, rompendo com o isolamento doméstico e aproximando os sujeitos de suas famílias (Oliver et al., 2002).

Acreditamos que diversas características e questões discutidas na literatura sobre as oficinas em saúde mental podem ser aplicadas à nossa experiência. Dentre elas, podemos citar: a intervenção a partir do desejo dos sujeitos, promoção da participação comunitária, o incentivo da circulação e das trocas interpessoais, a 
inserção na cultura e a promoção de momentos de lazer e entretenimento. Tem-se como premissa o respeito à diversidade humana e à singularidade dos sujeitos envolvidos, a promoção de cuidado e ações em direção à cidadania.

Nicácio (2004) sintetiza o que desejamos produzir no grupo de convivência, a partir de sua compreensão sobre as oficinas terapêuticas:

Lugares de validação de saberes e de fazeres, de descoberta e reconhecimento de linguagens diversas, de produção e de agenciamento de repertórios de conhecimentos e de projetos, de articulação e de potencialização de recursos socioculturais: tecer lugares de convivência, de relações e de afetos, de redes de pertencimentos e de trocas, propiciadores da ampliação de contratualidade e de enriquecimento da vida das pessoas com a experiência de sofrimento psíquico (Nicácio, 2004, p. 1).

Todas as questões apresentadas pela autora estão, em certa medida, presentes nos objetivos e na dinâmica do Grupo de Convivência Vida Nova: pretendemos criar um lugar de validação de saberes e fazeres para sujeitos que vivem a situação de pouco valor social; queremos que os sujeitos se comuniquem a partir de suas possibilidades, desejamos que tenham experiências de vida diferentes daquelas que possuem no dia a dia, marcado pelo isolamento e pela ociosidade; acreditamos na potência dos recursos comunitários; pensamos que conviver, conversar e trocar experiências, de modo fraterno e solidário sejam experiências inerentes à condição humana e que oferecem sentido para sua existência.

\subsection{A construção da convivência e da participação}

O Grupo de Convivência Vida Nova se desenhou por meio de um diálogo permanente entre necessidades e recursos, construído a partir do encontro entre pessoas, do desejo de estar juntos e compartilhar saberes e afetos. Sabemos que cada 
experiência territorial em reabilitação tem um desenho único, com atores e histórias particulares, que vivem num determinado contexto social e cultural. Contar essa história é o desafio deste trabalho.

Os primeiros contatos com a população adulta com deficiência moradora do bairro Cohab Raposo Tavares confirmaram a hipótese da condição de isolamento domiciliar e reduzida participação, como circular pelo bairro, frequentar escola, trabalhar, utilizar transporte público, ir à igreja, fazer compras, entre outras situações cotidianas. Para muitos, a única oportunidade de sair de casa é frequentar o serviço de saúde ou a escola especial.

Em contraponto com a ideia de isolamento domiciliar e ausência de oportunidades de participação, pensamos na organização de um grupo de convivência, tendo como apoio inicial o Centro Comunitário Raposo Tavares, coordenado por Padre Milton. Em contato que antecedeu o início dos trabalhos, Padre Milton mostrou-se bastante sensibilizado com a proposta e com os dados apresentados sobre a caracterização das pessoas com deficiência moradoras do bairro. Comprometeu-se em discutir o tema com o Conselho Paroquial, objetivando sensibilizar demais membros da igreja quanto à relevância social do tema.

Discutimos ainda a Campanha da Fraternidade de 2006, patrocinada pelo Fundo Nacional de Solidariedade da Conferência Nacional dos Bispos do Brasil CNBB e Cáritas Brasileira, que teve como tema "Fraternidade e Pessoas com Deficiência”. O cenário foi positivo para que, em 2006, encaminhássemos, através do centro comunitário, um projeto de apoio ao grupo de convivência ${ }^{13}$ à Caritas Brasileira, que apoiou financeiramente a consolidação da proposta assistencial.

\footnotetext{
${ }^{13}$ Centro Comunitário Raposo Tavares, em parceria com o Laboratório de Reabilitação com Ênfase no Território do Curso de Terapia Ocupacional da Faculdade de Medicina da USP e Unidade Básica de Saúde da Secretaria
} 
Recordamos o comentário do padre da comunidade diante da apresentação da pesquisa de caracterização das pessoas com deficiência da comunidade: que esta não seja mais uma pesquisa no bairro sem continuidade! Tal observação demonstrou sua expectativa em algum tipo de ação com relação à situação estudada. Em seguida fez outra solicitação: gostaria de receber alunos da USP, alunos de teatro, letras, para ensinar inglês e espanhol aos moradores, pois considero relevante a experiência do estudante na dedicação à comunidade pobre. Esses pedidos parecem estar relacionados à representação que a Universidade de São Paulo possui para esta comunidade. O bairro está localizado próximo à Universidade e para muitos moradores, a USP é representada pelo Hospital Universitário, local de referência para o cuidado de saúde da população. Portanto, a USP está relacionada a uma ideia de assistência e de serviços de extensão à comunidade. Refletimos sobre o pedido de Padre Milton como sendo legítimo: qual será a contrapartida do estudo produzido, para a comunidade? E nesse sentido tínhamos o conforto de afirmar que o interesse pela pesquisa surgiu a partir de um trabalho prático e inédito, em andamento nesta comunidade.

A criação de um grupo de convivência dependia de um esforço coletivo, partilhado entre pessoas com deficiência, familiares, unidade de saúde, centro comunitário, comunidade em geral, projeto que fosse delineado a partir da necessidade coletiva e que tivesse as características e a dimensão do contexto local.

\footnotetext{
Municipal de Saúde de São Paulo, elaborou um projeto destinado a pessoas com deficiência de um bairro periférico da cidade. O projeto teve como objetivo promover a participação comunitária, dar visibilidade aos problemas enfrentados por esta população (isolamento domiciliar, exclusão dos processos educacionais e do trabalho entre outras) e discutiu o acesso aos direitos fundamentais. Pretendeu-se também divulgar o trabalho de Reabilitação Baseada na Comunidade como alternativa assistencial e de inclusão das pessoas com deficiência. O projeto visou à consolidação e ampliação de um grupo de convivência para pessoas com deficiência, familiares e comunidade em geral realizado semanalmente, no qual foram produzidos trabalhos artesanais e discussões. Também foi realizado um vídeo sobre a reabilitação com ênfase no território, abordando as características e estratégias do trabalho, que tem sido desenvolvido pela equipe, com vistas a sensibilizar gestores do poder público para criação de estratégias de atenção, que respeitem a diversidade humana.
} 
Assim, em março de 2006, organizamos o primeiro encontro entre as pessoas com deficiência, familiares, profissionais da unidade básica de saúde e lideranças comunitárias. Comemoramos a presença das pessoas ${ }^{14}$ e certo otimismo com relação ao resultado alcançado, de acordo com o diário de campo:

Primeiro encontro bastante exitoso pela presença de aproximadamente 34 pessoas. A divulgação realizada nos domicílios por estudantes, terapeutas ocupacionais e Agente Comunitária de Saúde (ACS) foi bastante importante. Parece que o contato realizado com as famílias em 2005 repercutiu na adesão das pessoas a este encontro. A ideia de dar continuidade ao trabalho de identificação das pessoas com deficiência através de uma proposta assistencial parece sensibilizar os participantes (março de 2006).

O convite, aberto para toda a comunidade, nos deu a dimensão da população que poderia participar do projeto assistencial. Chamou-nos atenção a presença dos familiares/cuidadores, dos jovens com deficiência mental e a heterogeneidade quanto à faixa etária das pessoas, com a presença de crianças com e sem deficiência e idosos. Neste momento não tínhamos clareza sobre quais frentes de assistência poderiam ser criadas (Grupo para cuidadores? Oficina de brincadeiras para crianças com e sem deficiência? Grupo para mobilização corporal para pessoas com deficiência física?), porém havia uma decisão prévia, pautada na experiência dos terapeutas ocupacionais coordenadores, quanto à necessidade de grupalizar as pessoas. O que não estava definido era o tipo de atividade que seria realizado e para isso era importante considerar o interesse das pessoas.

Perguntamos, então, sobre o que gostariam de fazer em grupo. Tinham interesse em aprender algum tipo de atividade?

\footnotetext{
${ }^{14}$ Participaram deste primeiro encontro: 07 familiares, 04 jovens com deficiência mental, 02 crianças com atraso no desenvolvimento global, 02 idosos com seqüelas de Acidente Vascular Encefálico (um com deficiência motora e outro com seqüelas cognitivas), 01 adulto com deficiência física, 01 adulto com deficiências múltiplas (física e mental), 01 adulto e 01 idoso com sofrimento psíquico. Dentre as pessoas sem deficiência e profissionais estavam: 03 crianças, 03 moradores da comunidade, 02 representantes do centro comunitário Raposo Tavares, 02 terapeutas ocupacionais, 03 estagiários de terapia ocupacional, 01 enfermeira e 01 agente comunitário de saúde, esta última, filha de uma senhora com sofrimento psíquico e que, portanto, também se caracterizava como familiar de uma pessoa dependente.
} 
Sr. Sergio, idoso com deficiência física, disse que tem gosto pela pintura em tela e desenha bem.

Clotilde, senhora com sofrimento psíquico, contou que sofre de dor crônica no ombro, mas se melhorar pode se tornar voluntária no grupo.

Elaine, jovem moradora do bairro, verbalizou que também gostaria de ser voluntária e tem preferência em atuar com jovens e crianças.

Osmar, jovem de 21 anos com deficiência mental, disse que tem vontade de dançar, mas mostrou-se confuso quando questionado sobre qual ritmo gosta de dançar e verbaliza: "tem que treinar direitinho!"”.

Marilene, senhora com deficiência física e líder comunitária, sugere atividade de teatro.

As mulheres citam diversas atividades artesanais de seu interesse: atividades com fios $e$ tecidos, como costura, crochê, tecelagem. Neste momento, Soraia, representante do centro comunitário, ofereceu a máquina de costura da instituição.

Outra ideia foi a atividade de culinária que entusiasmou as mulheres: fazer pão e comida nordestina.

Lembramo-nos das pessoas muito entusiasmadas nesse momento da reunião, num exercício de conjugar desejos, habilidades e recursos. Num grupo tão heterogêneo quanto ao tipo de interesse expresso, foram sugeridos diversos tipos de atividades, que revelaram o desejo de aprender, de explorar vocações, e oferecer cuidado ao outro (considerando a postura de quem desejava ser voluntário).

O encontro também foi um momento de diálogo sobre problemas enfrentados no cotidiano pelos moradores do bairro. A tônica foi dada ao tema transporte, um dos principais problemas do bairro. Embora ainda insuficiente, o bairro conta com transporte adaptado para deficientes nas duas linhas que servem esse território, fruto da reivindicação de moradores com deficiência, que utilizaram dados da pesquisa de identificação das pessoas com deficiência como instrumento de pressão política para colocação dos veículos adaptados. Tal fato foi discutido nessa reunião como um exemplo de luta por direitos sociais enfatizando a importância da organização dos moradores diante das demandas. No encontro, pessoas com deficiência e idosos deram seus depoimentos sobre situações vivenciadas de desrespeito e falta de 
sensibilidade por parte de profissionais do transporte e demais usuários. Esse tema é recorrente nos fóruns de pessoas com deficiência realizados na região, sendo um assunto central no que se refere à participação social das pessoas com deficiência.

O entusiasmo pela congregação dessas pessoas também era perceptível na figura de Padre Milton: "é necessário oferecer oportunidades, não ter vergonha de ser deficiente e fortalecer este grupo". Informou os participantes sobre a Campanha da Fraternidade da Igreja Católica do ano de 2006, “afirmando que seria um momento oportuno para dar visibilidade às questões referentes à deficiência e produzir ações concretas de inclusão dos deficientes na comunidade”.

Padre Milton é considerado uma liderança comunitária sensível às questões sociais e políticas, uma figura carismática e respeitada na comunidade local. O apoio direto dessa liderança através de sua presença e da concessão do espaço físico do centro comunitário para realização do grupo de convivência foi valoroso para o início da construção da proposta assistencial.

\subsubsection{Espaço de encontro: Centro Comunitário Raposo Tavares}

Criado em meados de 1994 por iniciativa da comunidade católica, o centro comunitário oferece atividades religiosas, educacionais, sociais, culturais, de cuidado à saúde e geração de renda, contemplando crianças, jovens, adultos e idosos moradores do bairro. Dentre as atividades realizadas destacam-se: catequese, alfabetização para jovens e adultos, grupo da terceira idade, cursos de corte e costura, crochê, pintura em tecido, judô para crianças, atividades organizadas a partir do interesse de voluntários. São realizados grupos corporais de tai chi (coordenado por 
terapeuta ocupacional da UBS) e diversas atividades de educação em saúde e reuniões de profissionais da UBS Jardim Boa Vista que atendem a população local. O Centro Comunitário também participa do Programa Viva Leite do Estado de São Paulo, que realiza doação de leite às famílias cadastradas. Considerando todas as frentes assistenciais descritas, atende aproximadamente 500 famílias por mês.

Segundo o presidente da instituição, no início da década de 1990, o local onde provisoriamente funcionava a escola municipal de ensino fundamental, foi concedido ao centro comunitário pela prefeitura municipal. Ele é composto por uma sede (salão social) construída de alvenaria, com cozinha e dois banheiros (que não possuem dimensões adequadas para o acesso de cadeira de rodas) e três salas de atividades, construídas em aço modular (as salas de “lata”). A precariedade da estrutura, por muitas vezes nos incomodou, como expresso no diário:

O calor de hoje incomodou muito as pessoas. Conversei com S. (secretária) e obtive autorização para realizar o grupo no salão da secretaria, na próxima semana. A falta de condições estruturais (ventilação, iluminação, higiene) é uma situação concreta que precisa ser pensada e discutida com o grupo e apoiadores. Utilizar este recurso comunitário traz desafios e possibilidade (segundo encontro do grupo de convivência).

A quem o lugar, mal ventilado, iluminado e sujo incomodou? Talvez para a realização de um grupo, este não seja o espaço idealizado por um terapeuta. Este lugar, marcado pela precariedade material, por um modo particular de organizar o espaço que não é o mesmo de técnicos e estagiários, um espaço destinado ao coletivo, mas que poucos se responsabilizam em limpá-lo e arrumá-lo, por vezes foi motivo de reflexões e questionamentos. Nas visitas domiciliares de alguns integrantes do grupo, também nos deparamos com moradias que possuíam uma organização própria: faltava espaço, privacidade para seus moradores, iluminação, ventilação, o calor era intenso e a água, escassa. Quesitos importantes para garantir o 
direito a uma vida saudável. Nesta relação entre moradia e a "sala de lata”, realizar o grupo em condições mais favoráveis foi um dos motivos que nos mobilizou a encaminhar o projeto à uma agência financiadora. A verba foi utilizada para comprar cadeiras, mesas, armário, ventiladores e materiais de artesanato, que foram organizadores concretos do grupo. Do improviso, partimos para o uso mais permanente e organizado do espaço, lugar que foi sendo conquistado aos poucos a partir da consolidação e do reconhecimento positivo do grupo no centro comunitário.

A falta de estrutura do espaço está relacionada às questões de ordem política e administrativa. A administração pública local não concede o uso permanente do terreno para o centro comunitário, o que impede que a instituição invista em melhorias estruturais nessas edificações, já que a prefeitura pode, a qualquer momento, requisitar o terreno para realização de outras construções.

Tal fato confere precariedade da edificação para realização de todas as atividades assistenciais, sendo a concessão permanente do terreno uma das reivindicações do centro comunitário junto ao poder público. Nesse sentido, a reforma das instalações da instituição pode beneficiar toda a comunidade, inclusive as pessoas com deficiência, que teriam um espaço mais adequado e confortável para usufruir. Possivelmente, este seria um dos temas discutidos com as pessoas com deficiência, na tentativa de reunir esforços e organizar com demais usuários do centro comunitário estratégias de pressão política junto ao poder público para a cessão do espaço.

O centro comunitário é um local de intensa circulação social, frequentado por muitos moradores do bairro que usufruem das atividades aí realizadas. Porém, até o momento da organização do grupo de convivência, as pessoas com deficiência não 
frequentavam esse recurso social. O local é de fácil acesso aos moradores e não existem barreiras arquitetônicas expressivas que dificultem a chegada de pessoas com mobilidade reduzida ao local. A facilidade no acesso bem como a diversidade de atividades oferecidas nos fez pensar na importância de sensibilizar serviço e comunidade para a participação de pessoas com deficiência nesse espaço comunitário, usufruindo dos seus recursos e servindo de espaço de encontro dessa população. A presença de pessoas com deficiência neste local seria uma estratégia para dar maior visibilidade às questões referentes à deficiência e sensibilizar a comunidade para o tema. Repensar os preconceitos, promover um pensamento mais crítico sobre as condições de vida dessa população e fomentar a ideia de que esses sujeitos possuem direitos foram algumas das perspectivas que tínhamos e que nos motivaram nesse momento de instalação do grupo. Em que medida os profissionais da unidade de saúde, familiares, pessoas com deficiência e comunidade em geral se envolveriam com a proposta? Que apoios o grupo teria para se constituir, além destes que já foram citados? Quem participaria e qual seria a motivação dos sujeitos para a participação? Hipóteses e perguntas que permearam todo o processo de organização e acompanhamento do grupo. A seguir, a apresentação dos participantes do grupo de convivência.

\subsubsection{Os participantes do Grupo de Convivência Vida Nova}

Embora o estudo tenha focado as pessoas com deficiência adultas (18 a 60 anos) apresentaremos todos os participantes (adolescentes, adultos e idosos com 
deficiência) e jovens com sofrimento psíquico, que compareceram ao grupo com frequência superior a quatro encontros.

Leandro, 35 anos, apresenta deficiência intelectual, denominada, segundo informações da mãe, como oligofrenia severa. Frequentou a Associação de Pais Amigos de Excepcionais APAE na cidade de São Paulo, por aproximadamente 14 anos, onde também realizou tratamento em fonoaudiologia. Leandro não é alfabetizado, realiza as atividades de autocuidado com independência e circula, apenas, no bairro onde mora. Segundo a família, Leandro é alcoolista e sofre restrições para sair do domicílio, pois nestas circunstâncias tem acesso à bebida alcoólica. A mãe acredita que "se tivesse outra coisa para fazer não sairia para beber”. Leandro nunca trabalhou e neste momento não participa de atividades sociais. Participou do grupo de convivência nos cinco primeiros encontros. Após esse período se ausentou. Familiares informaram que ele havia piorado quanto ao uso de álcool e fora encaminhado para a casa do irmão, num outro bairro da cidade.

Pedro, 24 anos. Apresenta quadro de sofrimento psíquico, com hipótese diagnóstica de distúrbio bipolar. Segundo sua mãe, Pedro sofreu hipóxia cerebral durante o nascimento. Ela relatou a presença de crises convulsivas na infância e um surto psicótico aos 21 anos de idade. O jovem estudou na rede regular de ensino, onde concluiu o ensino médio, com histórico de baixo aproveitamento escolar. Realiza "bicos” como vendedor de cosméticos e refere que essa atividade é pouco lucrativa. Gosta de jogar dominó, assistir televisão, escutar música, fazer lições referentes ao curso de inglês e relata dormir muito, consequência do uso de psicofármacos. Passou a frequentar assiduamente o grupo de convivência a partir de junho de 2006, por indicação de Tia Mia, voluntária no grupo. Mostrou-se muito receptivo ao contato social, comunicativo, independente e criativo na confecção das bijuterias, o que provocou dúvidas, por parte das terapeutas ocupacionais, quanto às possíveis demandas e aquisições de Pedro num grupo de convivência para pessoas com deficiência. Em contato com a mãe, ela verbalizou: "nós que temos filhos especiais, sabemos o quanto é difícil...” referindo-se ao filho como "especial”. Mas especial em quais aspectos? A criação de hipóteses dependia da convivência no grupo e da construção de um vínculo terapêutico para que conhecêssemos as características e demandas de Pedro e sua dinâmica familiar.

Damiana, 19 anos, foi encaminhada ao grupo em abril de 2006 pela médica da equipe de saúde da família responsável pela região. Segundo ela, em relatório de encaminhamento ao 
grupo de convivência: "Paciente apresenta dificuldades de aprendizado, não sabe ler, escreve apenas o nome, não sabe o dia da semana, mês, ano, não sabe data de nascimento, tem vergonha da situação. Há necessidade de estimular outras atividades”. Ela participou do grupo até agosto de 2006, quando mudou-se para outro bairro. Uma das principais características de Damiana era a excessiva timidez, porém vinculou-se ao grupo e mostrou-se mobilizada com a atividade de confecção de bijuterias.

Kelly, 27 anos, é uma jovem que na infância foi diagnosticada com "atraso no desenvolvimento global”. Apresenta deficiência intelectual e disfagia, alimentando-se apenas com comidas pastosas. Caminha com independência, porém com dificuldades e necessita de supervisão para realizar atividades de autocuidado. Há 12 anos frequenta escola especial, porém, segundo a mãe, ela "odeia a escola". Sua mãe considera a escola especial excelente e acha que a inclusão escolar não funciona. Kelly gosta de riscar papéis (não é alfabetizada) e ver televisão. "Conhece todo mundo mais não tem amigos”. Segundo a mãe, Kelly é muito “grudada à mãe”. A jovem frequentou o grupo de modo pouco sistemático até setembro de 2006, quando se recusou a participar da experiência. Segundo a mãe, essa recusa está relacionada à presença de um jovem com psicose no grupo com o qual já havia convivido na escola especial que frequenta.

Janaína, 16 anos, é uma jovem bastante extrovertida, com Síndrome de Willians, relacionada, entre outros fatores, com a presença de atraso no desenvolvimento cognitivo e comprometimentos cardíacos. A jovem frequenta escola regular, é independente nas atividades do cotidiano e possui amigos, tanto no bairro onde mora, quanto no Conselho Municipal da Pessoa com Deficiência, do qual sua mãe foi presidente no período entre 2005 e 2007. Tem frequentado o grupo de convivência desde agosto de 2006.

Valdomiro, 35 anos, é conhecido no bairro como "Escuro" e "Negão". Aos dois anos contraiu meningite e, após esse evento, apresentou atraso intelectual e alteração no comportamento. Segundo sua irmã e tutora, Valdomiro saiu do hospital "esquecendo as coisas”. Foi encaminhado para um ambulatório médico de especialidades e, após avaliação clínica e psicológica, foi diagnosticado um "problema na veia da cabeça” (sic). Frequentou escola regular, mas não obteve êxito na aprendizagem. Também não se adaptou à classe especial para alunos com deficiência. Dos 15 aos 22 anos frequentou o projeto Circo Escola, onde realizou atividades de artes plásticas e teatro. Ele identifica números, reconhece cores, porém não é alfabetizado. É totalmente independente nas atividades de automanutenção, 
porém depende da irmã para tomar decisões particulares. Trabalhou como faxineiro, mas foi demitido por ter conflitos com o colega. Gosta de ver televisão, ouvir rádio e visitar familiares no bairro. Participa assiduamente do grupo, desde outubro de 2006, quando foi encaminhado pela secretária do centro comunitário.

Maria Regina, 57 anos, trabalhou como copeira nos restaurantes da USP durante trinta anos. Há oito interrompeu a atividade profissional, em razão de um acidente vascular cerebral. Teve como sequela uma hemiparesia: caminha com dificuldade, utilizando o apoio de bengala. Realiza as atividades domésticas e de autocuidado com independência, com leve dificuldade para executar ações que exijam destreza bimanual. Freqüenta atividades na Igreja Católica, faz parte do grupo da Terceira Idade do bairro e realiza atividade corporal de tai chi. Relata gostar de assistir novelas e conversar com as vizinhas. Mora sozinha em uma casa situada no mesmo quintal onde seus quatro filhos residem. Participa do grupo desde setembro de 2006.

Mariana, 22 anos, apresenta hemiparesia e deficiência intelectual, resultante de encefalopatia crônica não progressiva na infância. Apresenta convulsões e utiliza medicação psicotrópica. Segundo familiar, ela nunca realizou tratamento em reabilitação e não frequentou escola. É uma jovem que demonstra gostar do convívio social, é comunicativa, gosta do contato físico com as pessoas. Tem preferência por assistir televisão, rabiscar papel e permanecer na loja da avó. Mariana é cuidada por duas irmãs adolescentes. Pai e mãe trabalham em horário comercial. A jovem participou do grupo de convivência durante quatro encontros. Em junho de 2006 a família mudou-se para outra cidade.

Alice, 16 anos, nasceu em Recife e desde maio de 2005 vive em São Paulo com a bisavó e a irmã. Segundo esta senhora, a jovem possui problemas de cabeça e está na cidade em busca de tratamento. Frequenta escola regular (terceira série do ensino fundamental) e sala de apoio à inclusão para alunos com deficiência intelectual. Para a bisavó, foi nesta escola que Alice aprendeu a ler e escrever. É independente nas atividades do cotidiano como autocuidado e limpeza da casa, porém não tem autonomia para tomar decisões pessoais. Frequentou o grupo de convivência até o ano 2007, quando passou a estudar no mesmo período em que era realizado o grupo.

Celeste, 80 anos, apresenta deficiência auditiva severa. Seu marido faleceu em 2006, apresentava quadro de afasia, disfagia e deficiência auditiva, decorrentes de tumor na 
laringe. Após a morte do marido, Celeste passou a sentir-se muito sozinha no apartamento onde mora e foi conduzida ao grupo por uma vizinha, a partir de outubro de 2006.

Yago, 17 anos, apresenta hipótese diagnóstica de psicose infantil. É um jovem alegre, tendo como principal característica a agitação psicomotora ${ }^{15}$. Realiza psicoterapia e tratamento medicamentoso. Não é alfabetizado, foi inserido em escola especial e em equipamento público de ensino regular, porém, segundo a mãe, não foi aceito em nenhuma instituição. Yago apresenta boa comunicação e, às vezes, refere conteúdos delirantes. Gosta de ouvir música e recolher sucatas pela rua. Participou do grupo de convivência desde agosto de 2006.

As pessoas entrevistadas para a pesquisa: Osmar, Antonia, Marisa, Rosa e Adriano, serão apresentadas a seguir.

\section{Osmar}

Osmar (O.) é um jovem de 21 anos, muito conhecido no bairro onde mora. Todos se referem a ele como o "menino que mexe no lixo", um rapaz negro, forte e que, segundo os moradores, é deficiente, não compreende muito as coisas. Osmar é bastante requisitado por familiares e pessoas da comunidade para realizar tarefas que exijam força física: limpar, lavar, carpir, carregar entulho e materiais de construção. Ele conta que é remunerado e sempre que recebe algum dinheiro leva-o para a mãe. O. não sabe ler nem contar dinheiro, e em alguns casos recebe alimentos em troca do seu trabalho. Comida salgada, gorda, pouco nutritiva, às vezes estragada e que tem afetado negativamente sua saúde. Mora com a mãe, o pai e sete irmãos. Contribuem para a renda da casa o pai (autônomo, realiza trabalhos de pedreiro) e os dois irmãos mais velhos. A mãe conta que O., logo ao nascer, apresentou infecção por salmonela,

\footnotetext{
${ }^{15}$ Segundo o DeCS (Descritores em Ciências da Saúde), o termo é definido como sendo um sentimento de agitação associado com atividade motora elevada. Pode ocorrer como uma manifestação de toxidade do sistema nervoso ou outras condições. Disponível em http://decs.bvs.br/cgi-bin/wxis1660.exe/decsserver/
} 
permaneceu seis meses internado e demonstrou atraso no desenvolvimento motor e cognitivo. Aos sete anos foi inserido em escola de ensino fundamental do bairro, porém comia lixo e jogava os cadernos no chão. A mãe relata que procurou instituições especializadas em educação especial para deficientes intelectuais, mas não obteve êxito. Somente aos 19 anos passou a ser atendido em um serviço de saúde para adolescentes, onde foi diagnosticado ${ }^{16}$ e encaminhado para solicitação do benefício de prestação continuada. Nesse mesmo período foi identificado pelos profissionais de terapia ocupacional, sendo convidado a participar do grupo de convivência. Desde então frequenta assiduamente as atividades do grupo, no início com grande dificuldade para situar-se no tempo (equivocava-se com o dia da semana e com a hora da atividade). Demonstra gostar de produzir bijuterias, é caprichoso e mantém-se concentrado naquilo que faz. Relaciona-se de modo singular com as pessoas do grupo; é divertido, costuma fazer a mesma pergunta diversas vezes como forma de elaboração dos conteúdos. Às vezes se mostra hostil ao contato social. Entrevistar O. foi um desafio para a pesquisadora, um convite inédito ao jovem, que normalmente fala pouco, revelando ideias importantes, porém no contexto de uma narrativa entrecortada por situações que emergem de acordo com seu interesse e pela dificuldade de compreender o interlocutor. Sua fala, composta por frases curtas, muitas vezes formadas por outras perguntas, revelam um jovem ansioso quanto às oportunidades que lhe são oferecidas. As informações dadas por O. foram complementadas pela mãe Marlene, que em outro momento concedeu entrevista em seu domicílio. Marlene, 45 anos, trabalha informalmente como faxineira e vendedora. Relata que o filho O. “não é muito chegado ao pai” (sic), pouco se

\footnotetext{
${ }^{16}$ Segundo neurologista, O. possui transtorno de personalidade e de comportamento devido a doença, a lesão e a disfunção cerebral - CID F73.
} 
relaciona com os irmãos e prefere a mãe: "ele gosta é de ficar enchendo o meu saco" diz. A mãe se mostra muito enérgica quando necessita repreender os filhos: “... se eles brigam eu já corto logo (...): pronto, acabou!. No contato com a pesquisadora, Marlene revelou percepções importantes acerca do filho e suas relações sociais.

\section{Antonia}

Frequentemente encontramos Antonia (A.) nas ruas e nas casas do bairro, quase sempre com uma fisionomia triste, quieta, mas receptiva ao contato social. Seus amigos lhe oferecem alimentos, trabalho e companhia para uma boa conversa. Uma mistura de solidariedade e solicitação de sua força de trabalho. Seu corpo apresenta sinais intensos de sofrimento: aos 54 anos, A. já apresentou quatro episódios de acidente vascular encefálico - AVE, o último ocorrido há onze anos. Revelou ter sido alcoolista desde os 21 anos e só cessou o uso da bebida após os episódios de AVE. A. casou-se e separou-se três vezes. Teve dois filhos com o primeiro marido, que faleceram ainda bebês. No segundo relacionamento gerou Jorge (30 anos, desaparecido) e Débora (27, mora na Bahia). Já no terceiro casamento, teve Cintia (21, que concedeu a entrevista) e Janaína (18 anos, vive com uma tia). A. apresenta um pensamento moroso e demonstrou dificuldades em localizar temporalmente as informações que concedeu na entrevista, prejuízos relacionados ao alcoolismo e aos AVEs. Relata ter dificuldades de memória e não lembra com exatidão os fatos, datas, falando mais das sensações e enfatizando o discurso no sofrimento. A. é negra, apresenta hemiplegia do lado esquerdo e tem dificuldade para realizar atividades bimanuais. Sempre está com pernas e pés inchados, o que dificulta o caminhar. A. não possui o benefício de prestação 
continuada, sendo esta sua principal demanda neste momento. Realizou algumas perícias médicas, porém o médico avaliou que A. estaria apta ao trabalho. O profissional sugeriu à paciente que procurasse realizar exame de Tomografia Computadorizada das estruturas cerebrais, pois uma alteração nesse exame poderia ser considerada para a aquisição do benefício. A. aguarda realização do exame em lista de espera através do Sistema Único de Saúde. Seu sustento provém da ínfima remuneração que recebe por trabalhos que desenvolve na comunidade, como limpeza e cuidado de idoso. Mora com a filha Cíntia, de 21 anos, em uma casa alugada com um cômodo. Cíntia trabalha formalmente no setor de limpeza e, embora esteja feliz por possuir um emprego formal, relata que o dinheiro custeia apenas as despesas de moradia (aluguel) e alimentação. Contou que aos 10 anos de idade teve sua infância interrompida para cuidar da mãe que sofrera AVE e aceitou o convite de narrar alguns momentos da vida de sua mãe, que ficaram obscuros para a pesquisadora no primeiro encontro. Falou sobre a aquisição da deficiência da mãe e suas percepções sobre o tema. A entrevista foi acompanhada pela mãe e proporcionou um momento de diálogo entre as duas, o que há muito tempo não ocorria, sendo uma oportunidade de a filha expor sentimentos silenciados pela aspereza do dia a dia. Momento de reflexão e exposição, testemunhado pela pesquisadora. A. freqüentou o grupo de convivência na comunidade. Atualmente está afastada, pois tem se dedicado a um trabalho de limpeza de um estabelecimento comercial do bairro. 


\section{Marisa}

Marisa (M.) tem 46 anos de idade e desde o nascimento apresentou atraso no desenvolvimento global (motor, cognitivo e da fala), decorrência de uma encefalopatia crônica não progressiva na infância. M. é uma mulher que demanda muita ajuda dos familiares para realizar atividades do cotidiano, como higiene, vestuário e alimentação. Locomove-se com independência nos espaços domiciliares, porém necessita de ajuda para deslocamentos mais longos. Comunica-se verbalmente, porém existem dificuldades fonoarticulatórias que dificultam a compreensão por parte do interlocutor. Em suas falas, solicitações e comportamentos observa-se um perfil imaturo por parte desta mulher, que há pouco tempo se dirigia às terapeutas ocupacionais como “tias”. Marisa é a caçula de quatro irmãos. A irmã mais velha, Ana (58), é atualmente sua cuidadora principal. Sua mãe (Joana) faleceu em 2007, apresentando doença de Parkinson, demência e deficiência visual. M. nasceu em São Paulo e viveu infância, adolescência e parte da vida adulta com a mãe, viajando por várias localidades do Brasil, de acordo com as necessidades econômicas. Ambas foram morar com Ana na Cohab Raposo Tavares em 1997, pois Joana havia entrado em conflito com vizinhos da casa onde residia. Ana relata saber pouco da história da irmã (por exemplo, não sabe dados mais detalhados sobre o tratamento em reabilitação realizado pela irmã) e que, em principio, seu contato com ela foi um choque, já que não sabia como lidar com as suas incapacidades. Ana, 58 anos, é aposentada e relata que se sente estressada física (sofre de artrose nos joelhos) e emocionalmente por conta da assistência que ofereceu à mãe e dos cuidados de Marisa. Desde o ano de 2005, Marisa participa das atividades direcionadas às pessoas com deficiência atendidas na Unidade Básica de Saúde do 
Jardim Boa Vista. Atualmente frequenta os grupos de convivência Mosaico e Vida Nova. Neste mesmo ano passou a participar das atividades do Conselho Municipal da Pessoa com Deficiência, em reuniões, seminários e passeios. M.mostra-se insistente e imatura, solicitando a atenção dos profissionais o tempo todo, seja para apreciar o que está realizando (parece querer receber elogios?), para contar algo que ocorreu na família ou quando necessita de ajuda. Em entrevista, retomou o tema de seu comportamento, e verbalizou que se acalmou mais, que não está brigando com ninguém. Atribui sua irritação à falta de atividades, e enfatizou positivamente os passeios e a frequência nos grupos de convivência. M. compreendeu nossas perguntas, respondeu com frases simples, pareceu repetir a questão como forma de elaboração e compreensão do que lhe foi perguntado. Assim, temendo não ser possível transcrever a entrevista, repetimos, em diversos trechos, o que havíamos compreendido logo após a emissão de M., para obtermos sua confirmação. Observamos que existe a compreensão das situações, mas uma reflexão imatura, que se dá no campo do concreto. Percebemos que M. concedeu esta entrevista com muito prazer, sendo, talvez, um dos poucos momentos em que ela pôde ser ouvida com calma, sem a pressa do dia a dia que atropela seu ritmo de falar e que, muitas vezes, é desconsiderada pelo outro.

\section{Rosa}

Rosa (R.), 45 anos, conta que desde criança apresentou atraso no desenvolvimento motor e que demorou a andar, consequência de uma encefalopatia crônica não progressiva da infância, que resultou em hemiplegia. Demonstra muita dificuldade em caminhar, é obesa e seus pés estão sempre inchados. Além disso, 
possui muita dificuldade em realizar atividades bimanuais. Apresenta lentidão motora e psíquica, relacionada possivelmente uso de anticonvulsivantes e antipsicóticos. Relata que sua primeira experiência de trabalho foi aos 24 anos, quando desempenhou função como auxiliar de limpeza no Hospital das Clínicas de São Paulo. Após crises epiléticas foi readaptada para o cargo de recepcionista da creche da instituição. Nesse período sofreu outras crises (epiléticas ou psicóticas? Não há clareza no relato de R. quanto a essa informação), passou por internação psiquiátrica de 30 dias e foi afastada do trabalho para tratamento (dados referentes ao relato da mãe). Em 2000 foi aposentada, e o afastamento permanente do trabalho gerou intenso sofrimento à R. Atualmente mora sozinha num apartamento da Cohab Raposo Tavares e tem como principal queixa a solidão. No mesmo bairro mora sua mãe Iraci e irmã Magda, que se revezam nos demais cuidados de R. Atualmente é a irmã quem gerencia a aposentadoria, paga as principais despesas, compra comida e reserva uma verba generosa para os cigarros: R. chega a fumar três maços por dia. Seu cotidiano está restrito ao apartamento onde mora, mais precisamente ao quarto. Permanece quase o dia todo neste cômodo, onde assiste TV, escuta música e se alimenta. Seu apartamento carece de mobiliários: seu filho (22 anos) há pouco tempo deixou a casa e retirou móveis e utensílios domésticos, o que tornou a casa vazia e sem conforto. R. parece gostar de conversar e mostrou-se receptiva à ideia de ser entrevistada. Entre pausas, gestos, palavras duras e alguma dificuldade em organizar as ideias (consequência do uso de psicotrópicos), R. contou sobre sua história, porém sem tocar no tema sobre o distúrbio afetivo. Definia como “crises” alguns episódios, relacionando-as às crises epiléticas. O assunto foi abordado pela mãe (Iraci) que, numa situação imprevista, foi visitar a filha no momento da entrevista e foi 
estimulada pela pesquisadora a falar sobre R. na condição de mãe e cuidadora. Iraci acredita na hipótese de que a proteção da filha com deficiência tenha prejudicado sua maturidade emocional. Iraci é viúva, dona de casa, dedica-se à venda de alimentos e roupas usadas no domicilio. Possui nove filhos e reside em apartamento na Cohab Raposo Tavares com três deles. Frequentemente R. desloca-se até o apartamento da mãe para visitá-la. Estabelecem uma relação conflituosa, já que Iraci considera a filha voluntariosa e desaprova o uso intenso de cigarros. A fragilidade psíquica de R. foi sendo percebida pela pesquisadora ao longo dos contatos pessoais. R. foi convidada pela pesquisadora a participar do grupo de convivência Vida Nova, após a realização de diversas visitas domiciliares e a compreensão de que o isolamento domiciliar era sua principal queixa. Participou uma única vez e avaliou negativamente seu contato com o grupo: ficou muito irritada com algumas pessoas, principalmente com aquelas que possuem distúrbios afetivos, como, por exemplo, autismo. Nessa experiência, ficaram evidentes as suas fragilidades quanto à convivência social e a sustentação dos contatos interpessoais. Mantê-la como uma das entrevistadas neste estudo foi uma escolha que se pautou na tentativa de discutir uma situação muito comum entre as pessoas com deficiência: a presença de sofrimento psíquico atrelado, entre outros fatores, à condição imposta pela vivência da deficiência.

\section{Adriano}

Adriano (Ad.) tem 29 anos. A partir dos 16 apresentou cansaço e fraqueza muscular, principalmente nos membros inferiores, o que o fazia caminhar com dificuldade. Fez uso de muletas e há quatro anos tem utilizado cadeira de rodas. Em 
2005 obteve o diagnóstico de distrofia muscular tipo cinturas, sendo observada perda progressiva de força muscular de modo generalizado: necessita de ajuda para realizar transferências posturais e para executar atividades como higiene e vestuário. Gosta de realizar atividades artísticas, como pintura e mosaico. Ele não sabe ao certo sua escolaridade. Conta que frequentou ensino fundamental, mas enquanto todos aprendiam a ler e escrever ele passava de ano sem apresentar tais habilidades. Aos 16 anos, desestimulado pela falta de aprendizagem, pediu à mãe que o retirasse da escola, pois seu desejo era de trabalhar. Passou a trabalhar numa fábrica, como montador de geladeiras. Nessa função percebeu a piora do quadro da distrofia, o que o levou ao abandono do trabalho e ao pedido de aposentadoria por invalidez aos 27 anos de idade. Seu pai, Sr. João, foi o cuidador principal até 2007, quando faleceu. A mãe, D. Alzira (66 anos), passou a desempenhar essa função, porém com muita dificuldade, pois apresenta problemas de saúde. Ad. reside em casa própria com o dois irmãos: o mais velho (31 anos) é psicótico e dependente químico, e o mais novo (28 anos) também apresenta sinais da distrofia muscular, com dificuldades para caminhar. Ad. possui aposentadoria por invalidez e a mãe recebe a pensão deixada pelo marido. Ad. passa os dias em casa e, quando tem auxílio, é deslocado até a parte frontal do domicílio, onde permanece observando o movimento da rua. Duas vezes por semana participa do grupo de convivência Mosaico (locomove-se até o local com

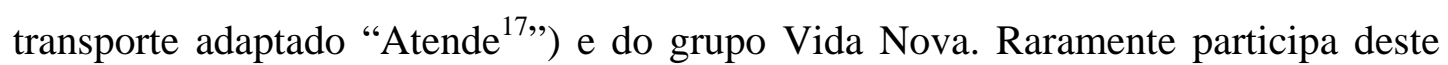
último, pois embora seja realizado no seu bairro, tem dificuldades para locomover-se até o local. As entrevistas foram realizadas em dois dias, com o acompanhamento de D. Alzira, que complementou as informações dadas pelo filho. A entrevista teve a

\footnotetext{
${ }^{17}$ Serviço Atende, um programa da secretaria municipal de transportes do município de São Paulo, que oferece transporte gratuito em veículos especiais, com hora marcada, a portadores de deficiência física.
} 
duração de aproximadamente duas horas e meia, tempo que surpreendeu as expectativas de pesquisadora, já que Adriano fala pouco nos grupos de convivência dos quais participa. Embora a pesquisadora tenha esclarecido que a entrevista seria com Adriano e que outro encontro seria agendado com Alzira, a mãe manteve-se no local e participou ativamente da entrevista. Observamos que Adriano não se importou com a presença da mãe e deu seu depoimento com tranquilidade e sem constrangimento. Em alguns momentos eles divergiram nas respostas, discutiram, sendo uma situação interessante de ser presenciada pela pesquisadora. Nesses momentos pôde ser observada a relação de cumplicidade entre mãe e filho, uma situação presente no cotidiano dos dois, que estão sempre juntos. Ficou evidente que Alzira deseja falar de suas tristezas, dos conflitos familiares, e quando teve oportunidade de se pronunciar, o fez. Adriano estava disposto a falar, desejava dar um “tom formal” à sua entrevista. Começou: “primeiramente eu nasci aqui em São Paulo” e “por fim”... complementava uma ideia, procurando organizar em sua mente o que revelava à entrevistadora.

\subsubsection{Estrutura e organização do grupo e a presença dos participantes}

Os primeiros encontros ocorreram a partir de março de 2006, reunindo pessoas com deficiência, familiares, crianças com e sem deficiência ${ }^{18}$, pessoas da comunidade, agentes comunitários de saúde, enfermeira, duas terapeutas ocupacionais - coordenadoras do grupo e estagiários de Terapia Ocupacional.

\footnotetext{
${ }^{18}$ Nos primeiros encontros do grupo participaram crianças com e sem deficiências, moradoras do bairro. Embora tenham sido acolhidas nos primeiros encontros, o processo de grupalização, bem como a organização da atividade se tornou difícil pela diferença de faixa etária e de demandas de cuidado e atenção. Após determinado período, o grupo de convivência foi definido como uma atividade destinada a jovens e adultos, sendo as crianças transferidas para outra frente de trabalho assistencial, denominada Brincando na Cohab, que quinzenalmente reuniu crianças com e sem deficiência, no espaço do centro comunitário, para realização de atividades lúdicas.
} 
Estávamos felizes com a presença das pessoas, porém apreensivos com o desafio de coordenar um trabalho que reuniu pessoas com perfis tão distintos, considerando diferentes faixas etárias, sexo, tipo de deficiência, interesses e motivações, incluindo a presença de profissionais com os quais não tivemos experiência profissional anterior (enfermeira, agentes comunitários de saúde). Compartilhar a coordenação do grupo com outro profissional de terapia ocupacional foi uma experiência de apoio, aprendizado e sustentou diversos momentos de dúvidas e enfrentamento de situações difíceis.

A primeira tarefa dos integrantes do grupo ao chegar ao centro comunitário era a organização do espaço físico. Consistia na transformação da sala de aula (utilizada pelo projeto de alfabetização para adultos no período noturno) em sala de atividades.

Foi estabelecido certo enquadre que consistiu em rotinas presentes em todos os encontros: organização da sala, apresentação das pessoas quando havia a participação de alguém pela primeira vez. A maioria fala apenas o nome. Marisa (46) diz: meu nome é Marisa, eu faço mosaico e bijuteria. Osmar (21), sempre se nega a dizer o próprio nome: não vou dizer não! Quem eu sou? Valdomiro (35), numa das apresentações, disse que terá dificuldades para guardar os nomes das estagiárias, pois tem problema de memória. A maioria responde timidamente ao pedido de apresentarse.

Em seguida, era realizado o relaxamento corporal (massagem com bolinhas), depois a disposição do material sobre a mesa, a realização da atividade e a organização do espaço no final do encontro. Essa estrutura foi constantemente alterada, com a introdução de conversas paralelas, discussões coletivas, visitas, 
imprevistos e improvisos. O enquadre, com data, local e hora prédefinidos, foi importante para auxiliar os sujeitos a se organizarem temporal e espacialmente. Maximino (2001), em seu estudo sobre um grupo de atividades para pacientes psicóticos, refere a importância do enquadre, inclusive para demonstrar a disposição afetiva do terapeuta, em aguardar os participantes para o próximo encontro. Quanto às ações regulares, presentes na rotina do grupo, a autora discute que estas seriam “gatilhos” que provocam reações, contatos e aproximações com a experiência.

Quanto à organização do trabalho de sondagem das atividades a serem desenvolvidas, contamos com os poucos materiais existentes no setor de Terapia Ocupacional, como fios, tecidos, teares manuais, contas para produção de bijuterias (materiais reciclados) e solicitamos, ainda, que os participantes apresentassem diferentes técnicas e materiais para o grupo. Embora não houvesse a determinação prévia do tipo de atividade que seria realizada, havia, por parte dos terapeutas ocupacionais, a percepção da necessidade de realizar uma abordagem corporal dos problemas motores das pessoas com deficiência. Assim, convidamos os participantes a realizar um trabalho de relaxamento corporal, conhecido como "massagem com bolinhas”. A técnica consistia no toque corporal da parte posterior do tronco, realizado através de uma bola de tênis. O toque, intermediado por um objeto, facilitaria o contato entre as pessoas que pouco se conheciam, numa atitude de respeito e cuidado com o outro. Solicitamos a formação de pares (usualmente de um profissional e uma pessoa da comunidade) que se revezaram no papel de quem é massageado e de quem executa a massagem, numa relação de troca de papéis entre quem cuida e é cuidado. Todos foram orientados por terapeutas quanto à técnica corporal, constituindo-se um momento de aprendizagem. De modo geral, a 
intervenção corporal provocou reações positivas nos participantes: tenho que agradecer a Deus pela massagem, já que estava tensa antes dela (Esmeralda, 68, moradora do bairro). Essa atividade, além da promoção do bem estar físico e emocional, também pôde contribuir na promoção de uma relação interpessoal mais simétrica entre profissionais e sujeitos participantes, questão fundamental para a construção de uma intervenção no contexto comunitário, no qual as relações sociais e as trocas de saber estabelecidas são muito importantes. O trabalho corporal sempre é solicitado pelos participantes, já faz parte da estrutura do encontro e antecede a realização das atividades artesanais.

A apresentação de diferentes atividades artesanais ocorreu nos dois primeiros encontros do grupo de convivência numa postura mais ativa por parte dos profissionais: a terapeuta ocupacional trouxe livros sobre bijuterias e ensinou alguns participantes a confeccionar peças com papel reciclado, a enfermeira conhecia técnicas de confecção de bijuteria e tear manual, as agentes comunitárias de saúde contribuíram com atividades artesanais como cestaria com jornal reciclado, macramé e bordado. Foi um momento de conhecer o outro e se apresentar. Pequenos grupos experimentaram diferentes atividades artesanais, porém, não havia muita clareza por parte dos profissionais e estudantes quanto ao papel a ser desenvolvido por cada um. Nesse momento de muitos ruídos e incertezas, próprios de um projeto que ainda está por ser constituído, a insegurança esteve presente também para o profissional.

Sâmea (2002), a partir da teoria pichoniana sobre grupos, discute que o início de um processo grupal pode instalar duas ansiedades básicas: o medo da perda e o medo do ataque. Perda do que já é conhecido, dos referenciais que cada um possui. 
Medo do ataque do novo, que gera insegurança e o sentimento de não estar suficientemente instrumentalizado para lidar com o novo.

As pessoas com deficiência aderiram à atividade de confecção de bijuterias logo nos primeiros encontros. Essa escolha se deu, aparentemente pelos seguintes motivos:

disponibilidade de material bonito e atrativo;

facilidade da técnica, se comparada com outras atividades artesanais apresentadas;

presença de profissionais e voluntário no apoio para confecção das peças;

bom resultado estético das peças produzidas;

mobilização afetiva que o objeto provoca nos sujeitos, seja pelo interesse no uso das bijuterias confeccionadas, seja pelo desejo de presentear familiares e pessoas queridas.

Costa e Figueiredo (2004), ao discutirem as oficinas de geração de renda, acreditam na importância da inserção do produto na rede de trocas simbólicas que lhe conferem algum valor, que, de início, não é necessariamente financeiro. Antes da geração de renda, há uma etapa preliminar, relacionada ao valor que cada um atribui à sua produção. Nesse sentido o objeto tem valor simbólico.

Dentre os apoiadores do trabalho, refletiremos sobre a presença de agentes comunitários de saúde (ACS) no grupo de convivência, numa perspectiva de pensálos como multiplicadores e mantenedores de uma experiência comunitária em reabilitação enfatizando também o seu conhecimento acerca da história do bairro e de seus moradores. 
No início dos encontros, das dezesseis ACS que atuavam no bairro, cinco se envolveram com a organização do grupo de convivência no período de implantação da proposta. As motivações para participar, em grande parte, estavam no plano pessoal: uma delas era cuidadora de mãe com sofrimento psíquico e desejava que ela participasse do grupo, já que vivia isolada em casa, sem motivação para realizar atividades do cotidiano. Sua mãe não permaneceu no grupo, pois mostrava-se deprimida, fato que desmobilizou a participação da ACS.

A agente comunitária de saúde, permanece envolvida com sua produção. Acredito que sua mobilização em participar do grupo esteja relacionada ao bem-estar que a atividade lhe proporciona. Fez bijuterias muito criativas e tem o reconhecimento positivo por parte dos demais integrantes do grupo (segundo encontro).

Observei que as agentes comunitárias presentes (em número de três) quase não se relacionaram com as pessoas com deficiência. Parece não haver clareza quanto ao papel de apoiar e ensinar as pessoas com deficiência do grupo, existindo problemas na comunicação e planejamento das ações por parte da coordenação do grupo. As "agentes” estão isoladas, muito concentradas na realização das atividades de sua preferência (segundo encontro).

Talvez a presença de terapeutas ocupacionais e estudantes desta área tenha desestimulado a participação de outros profissionais, pela percepção de que existia apoio suficiente para manutenção do trabalho. Essa situação é uma das particularidades deste projeto, que realiza atividades de ensino a partir das demandas assistenciais. Nesse aspecto, a presença de estudantes de graduação nas frentes assistenciais produz uma contradição no âmbito da sustentação do trabalho: julgamos positiva a presença de estudantes na organização da assistência, porém há fragilidades e riscos no que se refere à sua continuidade, pela alteração no quadro de estagiários a cada semestre. Contar com o apoio de agentes comunitários de saúde seria uma forma mais permanente de prestar assistência, considerando ainda a 
preciosa contribuição deste profissional nas discussões e no acompanhamento de casos, já que residem no bairro e conhecem as famílias assistidas.

Nas reuniões realizadas logo após o término do grupo, profissionais e voluntários, que participaram do encontro eram convidados a conversar sobre os acontecimentos do dia, bem como a discutir casos ou situações referentes aos participantes. Era um momento de expressar diferentes saberes e pontos de vista (de técnicos e de pessoas da comunidade), e discutir a importância do papel de cada apoiador do grupo. Esses esclarecimentos repercutiram nos encontros posteriores, quando observamos uma atitude de maior vinculação por parte dos agentes comunitários junto às pessoas com deficiência:

Irani (ACS) permaneceu, durante todo o encontro, junto com M.(mulher com deficiência física e mental), auxiliando-a na confecção de um colar. Percebi ambas muito concentradas na atividade, no diálogo que estabeleciam e no compromisso de terminar aquele projeto, para que M. levasse o colar para casa. (quarto encontro).

Porém a desmobilização dos agentes comunitários de saúde em participar do grupo era aparente, com faltas frequentes e a efetiva ausência nos encontros posteriores. Acredito que essa desmobilização também possa estar relacionada à organização do trabalho cotidiano desses profissionais. Algumas verbalizaram que a desistência em participar do grupo de convivência se deu pela dificuldade em se responsabilizar por todas as tarefas delegadas a elas. Outras deixaram esse posto de trabalho buscando novas oportunidades de emprego.

O que se pôde observar foi a existência da participação de agentes comunitários de saúde nos primeiros seis meses de implantação do projeto, e a ausência desses profissionais no semestre posterior por questões pessoais e profissionais. Sensibilizar a participação de demais trabalhadores de saúde e voluntários no trabalho de reabilitação em contexto comunitário tem sido um dos 
desafios deste projeto, compreendendo que o caminho para a participação é percorrido a partir da sensibilização dos sujeitos e do sentido daquilo que se produz. Para uma das agentes comunitárias de saúde, em reunião geral da unidade de saúde: o grupo de convivência na Cohab foi muito importante para ela como um processo de aprendizagem de conviver com pessoas com deficiência.

E quanto aos voluntários envolvidos no projeto? Quem são? Quais os motivos aparentes para a participação?

Nas ações em contexto comunitário, sempre se questiona e se deseja a presença de voluntários no apoio às atividades. A OMS - Organização Mundial da Saúde (2004), em documento sobre a Reabilitação Baseada na Comunidade - RBC, aborda o tema sobre voluntários como sendo o núcleo dos programas. São atores sociais que sistematicamente dedicam seu tempo ao cuidado das pessoas com deficiência. Oferecem informações e ajuda (ensinar o modo de realizar atividades da vida diária, confeccionar adaptações, auxiliar no emprego de comunicação alternativa entre outras) e atuam também como defensores das necessidades das pessoas com deficiência.

Na literatura também há críticas sobre a participação de voluntários nos projetos de RBC, com as quais concordamos.

Finkenflugel (2005) apontou a importância do papel de supervisores e técnicos de reabilitação na formação dos apoiadores da comunidade (stakeholders). Discute que o poder exercido por esses apoiadores (por exemplo, o manejo do orçamento do projeto, seu planejamento e coordenação), bem como por pessoas com deficiência e seus familiares é reduzido e está concentrado na figura dos gestores do projeto, sendo importante a realização de ações e discussões que promovam a maior 
participação desses trabalhadores. Cheausuwantavee (2005) afirma que um dos problemas da RBC é a falta de interesse e sensibilidade da comunidade, sendo importante a realização de ações neste sentido. Sharma e Deepak (2003) estudaram o perfil do voluntariado da RBC em países da África e do Pacífico e verificaram alta rotatividade entre os voluntários: $63 \%$ deles doam seu trabalho através de uma decisão pessoal; 84\% não são pessoas com deficiência; a satisfação pelo trabalho está relacionada à eficiência em suas habilidades para realizar as tarefas, sendo a formação e a capacitação atividades esperadas. Foram relatadas as barreiras identificadas no trabalho dos voluntários (insuficiência do tempo de dedicação e dos recursos materiais disponíveis, falta de conhecimentos e habilidades específicas), bem como o desejo de remuneração.

Brinkmann (2004) chama os voluntários de “força de trabalho da RBC não remunerada" e considera a situação de pobreza no mundo e a necessidade e desejo que a população tem do emprego remunerado. Para a autora, falar no trabalho voluntário em RBC é algo inconsistente e irreal.

Em nossa experiência, também nos deparamos com uma comunidade pouco sensibilizada com as questões da deficiência. Sabemos do alto índice de desemprego na população local, principalmente entre jovens, e também estávamos preocupados com a capacitação daqueles que se aproximavam de nosso projeto (voluntários e agentes comunitários de saúde). Observamos que as pessoas apresentavam desejo e experiência em realizar atividades artesanais, porém não tinham contato com pessoas com deficiência. 
Após dois meses do início das atividades do grupo, duas senhoras, ambas frequentadoras da igreja católica e colaboradoras do Centro Comunitário passaram a freqüentar o grupo na condição de voluntárias.

O perfil dessas senhoras coincidiu com o estudo realizado por Souza e Lautert (2008) sobre o trabalho voluntário como alternativa à promoção de saúde de idosos. Nesta população, principalmente entre os aposentados, o voluntariado é uma prática comum e está em expansão, sendo possibilidade para manutenção de uma vida ativa e que promove o não isolamento do idoso. De maneira geral, o trabalho voluntário estaria dirigido a comunidades pobres, motivado pela solidariedade. Doa-se o tempo livre, sem exigência de remuneração.

Assim foi o caso de Tia Mia, como é conhecida no bairro, participante da Pastoral Social que realiza visitas às pessoas enfermas. É uma senhora que se mobiliza frente ao cuidado do outro, às vezes correndo o risco de infantilizá-lo. Sua função no grupo era a de oferecer o lanche da tarde. Sua presença passou a ser muito esperada pelos participantes: conviver com prazer, encontrar com as pessoas, fazer coisas bonitas e tomar um café juntos.

Outra voluntária foi Maura, moradora do bairro e colaboradora do Centro Comunitário. Além de gostar de realizar atividades artesanais, Maura revelou que, após ter se tornado viúva, permanecia triste em seu domicílio e a frequência no grupo de convivência foi uma boa justificativa para sair de casa. Participou das atividades até meados de 2008, quando se mudou de bairro. No grupo, revezava-se entre as atividades de apoio aos participantes e dedicação à sua produção de bijuterias.

Maura, voluntária, permaneceu envolvida com a criação de um colar com miçangas. Observo-a muito seduzida pela atividade (é um prazer para ela), ao mesmo tempo percebo que ela possui consciência de seu papel como apoiadora do grupo: verbaliza que deseja aprender para ensinar o outro. Maura, nas discussões, traz dados importantes sobre suas 
impressões da comunidade. Contou que, quando viu O. (21 anos, com deficiência mental) no grupo ficou preocupada, pois ele, num outro projeto assistencial, roubava os carrinhos que produziam. Maura é comunicativa e o seu discurso traz um pouco da representação social sobre as pessoas com deficiência (quarto encontro).

Numa outra situação observamos sua postura diante da atitude de traquinagem do mesmo jovem, que tomou para si os óculos de uma estagiária:

"Se você não devolver os óculos à estagiária, não te levo mais para passear!" (referindo-se a uma visita ao centro da cidade) e o jovem retruca: "Mas quem leva não é a senhora, é a Marta! (quarto encontro).

A infantilização das pessoas com deficiência mental é uma atitude presente nas relações sociais estabelecidas por estes sujeitos e que reproduz uma tendência da sociedade em tratar as pessoas com deficiências de modo paternalista e assistencialista. Essa atitude, muito presente no contato das voluntárias com os participantes do grupo, pode estar relacionada à própria condição de ser voluntário e à origem e vinculação desta modalidade assistencial com a religião católica que, difundida sob os preceitos religiosos, associou o voluntariado à caridade e ao humanitarismo (Souza; Lautert, 2008).

Por esses motivos, era fundamental a reunião de equipe após a realização do grupo, como forma de coletivizar as discussões sobre os participantes, sobre as situações vivenciadas, de modo a produzirmos direções convergentes que promovessem a maturidade emocional e os direitos dos participantes. Nesse sentido, desejávamos produzir um voluntariado solidário e que estivesse engajado, politicamente, na defesa dos direitos das pessoas com deficiência, bem como na melhoria da condição de vida para toda a comunidade. Desejávamos também que os voluntários passassem a fazer parte da rede de apoio das pessoas do grupo, o que pôde ser observado em Tia Mia com relação à Pedro (24) e Marisa (com quem Tia 
Mia tinha um vínculo mais estreito, e, por exemplo, promovia sua presença nas missas dominicais) e em Maura com relação à Osmar (21), com quem estabeleceu uma relação mais próxima e afetiva.

Quanto à presença dos participantes, das 48 pessoas com deficiências identificadas e cadastradas pelo projeto em 2005 e que foram convidadas a participar do grupo de convivência, 26 tiveram algum contato com a proposta, sendo que:

11 frequentaram o grupo de modo assíduo, durante os oito meses de estudo;

> 2 mudaram-se de bairro durante a realização de pesquisa ${ }^{19}$;

$>10$ frequentaram de um a dois encontros e;

$>3$ compareceram pelo menos a quatro encontros e depois abandonaram a experiência.

Os participantes mais assíduos do grupo foram aqueles que não estavam inseridos em atividades sociais cotidianas, sendo a grande maioria jovens com deficiência mental, jovens com sofrimento psíquico e senhoras que apresentavam algum tipo de deficiência.

Dentre os participantes, não havia apenas pessoas com deficiência, mas também pessoas da comunidade que, por algum motivo, se sentiram motivadas a participar. Eram três senhoras que não ocupavam a posição de voluntárias e, sim, de participantes; mostravam-se envolvidas com a atividade e contribuíam com diálogos e questionamentos, que enriqueceram os encontros. Sempre apoiamos a presença de pessoas da comunidade em nossos grupos, apostando na riqueza deste encontro. Não

\footnotetext{
${ }^{19}$ Mariana, jovem de 22 anos sexo feminino, possui deficiência física e mental, frequentou o grupo durante dois encontros e mudou-se de cidade.

Damiana, jovem de 19 anos, sexo feminino, possui atraso cognitivo, frequentou o grupo de modo assistemático, de abril a agosto de 2006, quando mudou-se de bairro.
} 
desejamos criar guetos, grupos apenas para pessoas com deficiência e cremos na potência do grupo de atividades quando ele se torna interessante para todos. Podemos citar o caso de D. Esmeralda (68), apoiadora da igreja, que “desejava relaxar no momento do grupo e aprender coisas novas”. Para Vilma (37), mulher bastante rechaçada pela comunidade, pois segundo moradores era hostil, alcoolista e não se responsabilizava pelo cuidado dos filhos, a participação no grupo foi um momento de resgate de sua feminilidade e autoestima.

A frequência dos participantes oscilou durante os 16 primeiros encontros, situação que gerou questionamentos, hipóteses e estratégias para estimular a participação. Após esse período, observamos menor oscilação na frequência, com no mínimo seis participantes por encontro.

A partir do terceiro encontro, a ausência dos participantes foi uma preocupação para os coordenadores do grupo. Sabíamos de algumas dificuldades colocadas à participação das pessoas, algumas objetivas, como é o caso da dificuldade de locomoção, outras mais subjetivas, como por exemplo, a falta de motivação para sair de casa.

Optamos por realizar visitas domiciliares àqueles que apresentavam alguma dificuldade para participar do grupo. As visitas domiciliares foram realizadas pelas coordenadoras do grupo e estagiários de terapia ocupacional e, nesse momento, o principal objetivo era o de conhecer as famílias, criar um vínculo social com familiares e explicar a proposta do grupo, convidando a pessoa com deficiência e familiares para participarem.

Compreendemos a visita domiciliar como um instrumento de intervenção. Ela tem sido realizada levando-se em conta a família em seu contexto social, sendo um 
momento importante de apresentação entre equipe e familiares. A visita, num primeiro momento, é exploratória e pretende oferecer escuta às questões levantadas pelos sujeitos. Não deve ser compreendida como uma intervenção de controle e nem um interrogatório. A equipe poderá apoiar a família na busca de soluções para problemas emergentes, refletindo sobre as alternativas e reconhecimento das competências (Costa; Brandão, 2004).

Nas visitas, nos deparamos com situações de conflito e sofrimento familiar. Tais situações estavam, dentre outros motivos, relacionadas com o lugar social ocupado pela pessoa com deficiência na família, muitas vezes de pouco investimento e restritas oportunidades de participação nos recursos comunitários. Nossa aproximação talvez tenha sido compreendida como um questionamento sobre esta condição, sendo recebida com cautela por parte dos familiares.

Este foi o caso de Leandro, 35 anos, que apresenta deficiência mental. Sua participação no grupo de convivência foi breve, frequentou os cinco primeiros encontros e no último compareceu alcoolizado. Nesta ocasião, mostrou-se muito confuso e agressivo verbalmente. Diante da situação, procuramos apaziguá-lo e o acompanhamos até seu domicílio, quando tivemos um contato com a mãe.

A mãe conta que logo cedo o avisou sobre a "escola" (o grupo de convivência), mas que não adiantou. L. saiu para a rua e recebeu bebida dos colegas do bairro. Neste momento de conversa, L. chorou e a mãe permaneceu com uma expressão facial severa, até mesmo áspera. Verbalizou que "não adianta", que o filho "não entende" (quinto encontro).

Esta foi a última vez que L. compareceu ao grupo de convivência. Posteriormente, nas demais tentativas de contato, realizados através de interfone e telefonemas, soubemos que L. estava hospedado na casa do irmão, onde, restrito ao domicílio, não teria contato com a rua. Num contato telefônico, percebemos a mãe 
bastante resignada e descrente com relação a qualquer intervenção terapêutica, inclusive um grupo de convivência. Para a família, a circulação de L. no bairro sem intermediação é considerada um risco e não uma oportunidade. A ideia idílica de comunidade, que segundo Bauman (2003) traz uma sensação positiva, de solidariedade e confiança, onde ninguém será ridicularizado, permanece longe do nosso alcance na contemporaneidade. Assim, para ter segurança, Leandro é apartado da vida comunitária.

Compreendemos a complexidade da situação e utilizamos outros recursos terapêuticos para abordar L. e sua família. Foram realizados atendimentos domiciliares com respaldo técnico da equipe de saúde da família, na tentativa de construção de um projeto terapêutico, que pudesse responder às necessidades de L. O grande desafio neste caso tem sido a abordagem familiar e a produção de mudanças no que se refere à falta de investimento em L., que segue sobrevivendo à condição de isolamento social e sofrimento psíquico.

Outro exemplo é o de Osmar, jovem com deficiência mental. Seu desejo de participar do grupo mostra-se claro e afirmativo. Mostrou-se assíduo, vinculou-se positivamente com profissionais e demais participantes e demonstrou envolvimento com as atividades realizadas. Porém, uma de suas fragilidades foi a falta de noção temporal e de apoio familiar para que se organizasse e participasse de uma atividade regular, com data e hora marcada, algo totalmente inédito em sua vida. Por diversas vezes, durante o período de observação do grupo, foram registrados os momentos em que terapeutas e estagiários realizaram a "busca” de Osmar no domicílio ou pelo bairro, para que pudesse participar do grupo. 
Osmar estava removendo areia de um local para outro. Ao me ver comentou sobre o bazar: eu vendi tudinho! Mostrou-se muito mobilizado por este assunto. Sônia, a proprietária da casa onde ele trabalhava, o dispensou, para que pudesse ir ao grupo. Mais uma vez, acredito que, se não houvesse procurado por ele, O. não teria ido ao grupo. Chegando a sua casa, a mãe pensou que o filho tinha feito algo de errado. Verbalizou que Osmar tem cabeça de "pica-pau", é esquecido e não se lembra dos compromissos. Marlene (mãe) o orientou a tomar banho. O. compareceu ao grupo logo depois, de banho tomado, inquieto, no meio da apresentação dos integrantes do grupo (décimo sétimo encontro).

Por diversas vezes, Osmar justificou seu atraso afirmando que estava trabalhando. O trabalho, tema central na vida cotidiana dos homens, também é priorizado por Osmar e por sua família.

Talvez, para os familiares, Osmar seria mais produtivo realizando os trabalhos no bairro, buscando comida e doações, recompensas que o grupo de convivência não lhe oferece. Porém, mesmo atrasado, ou sendo conduzido por profissionais e estagiários, Osmar comparece ao grupo, se envolve com a atividade e com as pessoas, até que surge a fome, tônica de sua vida cotidiana, e ele pergunta: hoje não tem lanche não?

Adriano, 29 anos, portador de distrofia muscular e usuário de cadeira de rodas, participou assistematicamente do grupo de convivência (dos 34 encontros, Adriano participou de 16 com intervalos irregulares). Ele foi conduzido pela mãe e em outras ocasiões por parentes que, ocasionalmente, estavam disponíveis. A partir da constatação de que Adriano necessitava de auxílio para o deslocamento, fizemos a proposta de apoiá-lo através da ajuda de estagiários. Nos primeiros encontros realizamos visitas domiciliares para sensibilizá-lo a participar.

Neste dia também visitamos Adriano, para avisá-lo do grupo. Ele compareceu ao centro comunitário, trazido pela mãe, momentos depois, sinalizando que a visita domiciliar pode ter sido um dos fatores que promoveu a sensibilização e organização da família para possibilitar a sua presença no grupo (nono encontro). 
A experiência do Grupo de Convivência Vida Nova vem demonstrando que, para garantir a presença de pessoas com deficiência graves (sejam elas motoras ou cognitivas) e bastante dependentes, é necessário um conjunto de esforços que transcendem o momento do grupo propriamente dito. A presença e a adesão das pessoas, algo crucial para a produção do encontro, requer estratégias de sensibilização e ações objetivas para promoção da participação. Não basta comunicar à comunidade que um grupo de convivência para pessoas com deficiência foi inaugurado e aguardar passivamente sua presença. Em nossa experiência, foi necessária a realização de uma busca ativa de pessoas que, normalmente, possuem poucas experiências de convivência e oferta de condições objetivas para que isto acontecesse.

Temos clareza que esta experiência territorial em reabilitação é singular e tem sido possível a partir da existência de uma estrutura de ensino e assistência que promove a participação de profissionais e estudantes, o que torna a assistência mais ampla e complexa. O trabalho depende do apoio institucional, neste caso de um centro comunitário, de uma unidade básica de saúde e da universidade. O que se pretende discutir nesta experiência são os recursos e as articulações necessárias e disponíveis para a concretização de um projeto assistencial com esta dimensão, que pretende atender pessoas com deficiência em sua própria região de moradia.

Acreditamos que a frequência dos participantes esteja relacionada com os bons momentos produzidos no grupo. Momentos de convivência, de trocas afetivas e da sensação de pertencer a um grupo e ser bem acolhido por aqueles que o constituem. Para que o grupo se desenvolvesse era necessário nutri-lo e desejar que as pessoas comparecessem. Esse foi um sentimento presente em nossa atuação e por 
diversas vezes registramos as preocupações diante da ausência dos participantes. Nas visitas domiciliares, procuramos provocar nos sujeitos alguma demanda ou curiosidade diante da possibilidade de participar de um grupo, sabendo que esta era uma experiência rara na vida dessas pessoas.

\subsubsection{As motivações para participar e a percepção das potencialidades e limitações}

Ah, com todos, gosto de conversar (...) com a estagiária, só quando eu tô muito entretido assim, aí não tem como conversar. Se você fica concentrado naquele negócio ali, você tem que ficar concentrado pra não fazer coisa errada. Fora isso você conversa com os outros ali, conversa, brinca com as pessoas, brinca lá com as pessoas assim, com os estagiários, com todos, eu gosto de conversar com todos ali (Adriano, 29, referindo-se ao grupo de convivência).

O grupo é assim, o que eu faço lá? (...)

Faço colar, faço, (...) um monte de coisa lá, um monte de coisa lá, um monte de coisa...

Um monte, do que? (entrevistadora)

Um monte de colarzinho (...)

E como é a preparação para ir para o grupo?

Preparação? Eu fico sabendo que eu vou hoje. Eu vou me arrumar. E fico alegrinha para ir pro grupo (Marisa, 46).

Pulseira é que mais dá dinheiro...

(...) e se não vender?

(...) você não vai levar pra vender esse daí?

(...) tem mais? Só tem isso? Cadê o resto?

(...) o resto tá lá no posto.... (entrevistadora)

E já vendeu tudo?

E o que você faz com o dinheiro, hein?

(...) ah, o dinheiro fica guardado pra comprar mais material, pra pagar alguma coisa que precisa... (entrevistadora)

A minha mãe falou que eu ganho pouco dinheiro...

(...) a minha mãe falou que eu ganho pouco dinheiro aqui...

(...) apesar de que eu não ganho muito...

....acho que a idéia desse grupo não é ganhar dinheiro, mas aprender a fazer biju, conversar com as pessoas... (entrevistadora)

(...) as pessoas não ganham muuuito, assim, né?

Não ganham, o que você ganha aqui, por que é que você vem?

(...) ah, trabaiá, né? (Osmar, 21 anos)

Os entrevistados falaram sobre a participação no grupo de convivência a partir da experiência concreta de fazer coisas: fazer colar, anel, pulseiras. A atividade 
é considerada com destaque pelos participantes: ela motiva e potencializa o fazer criativo, desafia e exige concentração, como diz Adriano, que opta pelos projetos mais difíceis. Até fazer a faxina, coletivamente, se torna um assunto para contar para os familiares; portanto, o encontro gera repertórios para o sujeito, tornando o cotidiano mais atraente. O grupo também promove entretenimento e oportunidades para conversar e se relacionar com o outro, realizar trocas sociais e afetivas, o que nos faz crer que a proposta tem respondido ao seu principal objetivo, que é promoção de convivência em contraposição ao isolamento domiciliar.

Embora não tenha sido constituído, a priori, como um grupo de geração de renda, a dinâmica estabelecida no grupo e acordada entre os participantes foi de que, após certo tempo de experiência confeccionando as peças de bijuterias, estas seriam vendidas para custear a compra de material para reposição das peças. Metade do valor da venda seria destinada a um fundo para o grupo e a outra metade para o autor da peça, como forma de estímulo e aprendizagem do valor e utilização do dinheiro. Para Osmar, por exemplo, o grupo possui status de trabalho, e vender o material produzido gera grande expectativa.

Osmar revelou que a família questionou seu "trabalho" no grupo de convivência, pois ele não seria rentável monetariamente. Entretanto, a mãe de Osmar apresentou um discurso sobre a inserção do filho no grupo de convivência e enfatizou o aprendizado, as transformações pessoais e validou a experiência como possibilidade de geração de renda.

Ele se diverte, ele fica doido quando vai ter passeio! (...) Na Vinte e Cinco (centro comercial da cidade) é bom porque abre a mente. Né? É bom. (...) falou aqui que o que vocês tão fazendo tem que ter muita, (...) paciência, porque nem todo mundo tem a paciência que você tem. Né? De ensinar, de fazer uma bijuteria, um brinco, isso aí a pessoa tem que ter paciência. (...)! Porque o O. tá até mais solto depois que começou a conversar com você, ele tá mais, é, conversador, né, ele já, já, uma vez pegou ônibus sozinho, entendeu? Então é bom, ajuda muito. 
Aqui uma contradição no discurso da mãe, que ora valida a experiência do filho no grupo de convivência (durante a entrevista, junto à pesquisadora) e ora o questiona, afirmando que o trabalho não seria rentável, e que talvez fosse mais produtivo O. investir nas atividades que já vem realizando no bairro como catador de entulhos em troca de remuneração e alimentos. O. está imerso no cotidiano da família, marcado pela urgência da sobrevivência, o que também lhe confere um lugar de quem participa da provisão de bens. Porém, quase não há investimentos e cuidado destinados ao Osmar, embora a mãe indique sua capacidade de aprender e se transformar pessoalmente.

A experiência do grupo de convivência também foi reconhecida como um lugar de geração de cuidado para pessoas com deficiências. Lidar com esta população, a qual Antonia, nomeia como “cri”... (criança?) requer uma atenção especial:

... é, pras pessoas com deficiência é uma beleza, porque eles também precisam aprender alguma coisa da vida, né?

... as pessoas que tem dificuldade, tem pessoas que ficam ...(empurrando), que não pode, as pessoas gritando, no grito não, (...) porque eu vou ficar brava com uma cri... com uma pessoa assim? ... tem que ter paciência com eles(Antonia, 54).

Para Pedro, 21 anos, portador de sofrimento psíquico, o grupo seria um curso que serve para ajudar as pessoas com deficiência e deve ser divulgado. As pessoas, para ele, devem ser valorizadas por seu jeito especial de ser, para crescer cada vez mais, assim como ele se desenvolveu nesta experiência (vigésimo quinto encontro do grupo de convivência).

Porém, conviver com pessoas com deficiência também pode gerar sofrimento e rejeição, sentimento exteriorizado por Rosa que, em entrevista, verbalizou sobre um dos motivos pelos quais não deseja participar desta experiência: 
Ah, eu não gosto. De ficar perto de gente com problema! Eu olho, mas me dá uma dor no coração de ver pessoas com problema e eu não poder ajudar!

Que tipo de problemas você viu ali que te tocou? (entrevistadora)

Ah, eu vi aquela senhora com pouca audição, eu vi aquele menino falando que nem um bebezinho, eu vi aquele rapaz que quando você falou, no passeio, se animou, (...) eu vi aquela senhora com deficiência na mão e mostrando que tava fazendo, mas o rapaz que tava ao lado tava ajudando. E aquilo tava me magoando... (Rosa, 45 anos).

O grupo é um espaço para conversar, fazer atividades, desenvolver habilidades e, para Osmar, um lugar para trabalhar. É um espaço onde se convive com as diferenças humanas, com pessoas com e sem deficiências, que provocam diferentes sentimentos nos sujeitos: ora compaixão, ora repulsa (no caso de Rosa). Para Marlene, é necessário ter paciência, zelo e dedicação para ensinar.

Perceber as potencialidades e os limites foi importante para pensarmos em estratégias de aprendizagem e cuidado.

A enfermeira acompanhou Leandro (35) orientando-o na atividade de confecção de bijuteria. L. não conseguiu realizar com êxito a atividade de confeccionar "enroladinhos de papel”, porém demonstrou bom desempenho na organização das contas (separação por cores e ordenação). Neste momento, observa-se a importância do papel de quem ensina e que dever estar atento às habilidades dos sujeitos, bem como a apresentação de alternativas que tornem possível o fazer. Ao mesmo tempo em que a enfermeira o auxilia, ela mantém um diálogo com L.,, uma chance de conhecê-lo melhor. Suas verbalizações são bastante simplificadas, no âmbito da representação concreta. Quando perguntamos sobre o seu final de semana, foi pouco claro, gesticulou bastante, como um cantor de rap, é muito animado e provoca risos no interlocutor (quarto encontro).

Neste encontro, Osmar (21) estava sujo e no inicio do grupo comentou comigo sobre o incômodo de estar mal vestido. Osmar mostrou-se muito concentrado na atividade. A bijuteria que produziu é simples, mas muito bonita. O. estava orgulhoso de sua produção, verbalizando que era "dele". Mostrou-se desestabilizado emocionalmente quando convidei a todos do grupo para o passeio ao Parque Ecológico do Tietê $\hat{e}^{20}$. Diante de uma situação inédita, mostrou-se inquieto motoramente e confuso com a tarefa de levar o convite por escrito à mãe. Parecia demonstrar algum temor de que a informação não chegasse à sua família e solicitou que eu informasse pessoalmente a mãe sobre o evento, e assim o fiz. Talvez o contato dele com a família seja conflituoso, e a intermediação da relação através

\footnotetext{
${ }^{20}$ O projeto de Reabilitação com Ênfase no Território promove, duas vezes ao ano, passeios a locais públicos de lazer da cidade de São Paulo. Estes passeios vêm sendo realizados desde 2004, com apoio do transporte adaptado Atende, da Secretaria Municipal de Transportes de São Paulo. São convidadas as pessoas com deficiência e familiares assistidos pelo projeto, moradoras dos bairros atendidos, congregando cerca de 50 participantes por evento. Em abril de 2006 as pessoas com deficiência moradoras da Cohab Raposo Tavares foram, pela primeira vez, convidadas a participar.
} 
de um papel por escrito (ele sendo analfabeto) seja um fator que dificulta a relação (quinto encontro).

Eu e Marisa (46) discutimos um novo projeto de confecção de bijuterias. Tenho que direcioná-la, dar dicas durante a execução da tarefa, pois M. apresenta dificuldades cognitivas importantes. A mobilização para participação de M. no grupo são as relações pessoais. Participou da conversa com Osmar, perguntou sobre a ausência de Mariana (22) e de Leandro (35), demonstrando que estas pessoas fazem parte da representação que possui do grupo.

Num determinado momento do encontro, D. Esmeralda verbalizou: "quem diria que a Marisa estaria aqui conosco após a morte de sua mãe!” Neste momento pensei na função do grupo enquanto suporte para enfrentamento de situações difíceis e o quanto os grupos de convivência dos quais Marisa participa (duas vezes por semana) têm auxiliado na superação da ausência da mãe, com a qual sempre manteve uma relação muito estreita (sétimo encontro)..

Leandro, Marisa e Osmar apresentam competências e limitações que foram sendo observadas no decorrer dos encontros. Os três apresentaram lacunas cognitivas importantes e Marisa, dificuldades motoras que exigiram apoio em diversas etapas da realização da atividade. A forma de comunicação também é particular para cada um. Leandro, gesticula e diz que tá tudo bom, mano! Osmar mostra-se com frequência inquieto, caminha pelo centro comunitário, fala pouco, mas no momento de realizar bijuteria, concentra-se, aquieta-se corporalmente e fica deslumbrado com o que consegue produzir. A inquietação motora e o medo aparecem quando ele está diante do inédito, do desconhecido (um aviso de passeio, um papel com letras que ele não reconhece). Marisa parece nem se importar tanto com a atividade de bijuteria, desconcentra-se com facilidade e gosta de observar os outros.

As relações que se estabeleceram neste momento foram duais: um participante e um profissional (a enfermeira, a terapeuta ocupacional ou um estagiário). Diante da situação inédita de participar de um grupo e realizar bijuterias, observamos que as parcerias foram muito presentes em todo trabalho, o que caracterizou o grupo como um espaço de promoção de aprendizagem e cuidado. 


\subsection{O desenvolvimento da experiência: o grupo como possibilidade de promoção de aprendizagem e cuidado}

Neste encontro, apresentei alguns materiais de bijuteria inéditos ao grupo e lancei uma proposta de regulação e restrição do uso do material por parte das crianças, proposta que foi aceita por todos. Percebemos que existe pouca autonomia por parte dos participantes adultos na escolha do material, na projeção da atividade e na resolução de problemas. Aceitam o que lhes é colocado, numa relação de muita passividade e delegam as decisões à coordenação do grupo. Assim, aceitaram a proposta de confeccionar bijuterias para o dia das mães, para presentear alguém da família... (quinto encontro).

Sâmea (2002) aborda o conceito de aprendizagem na teoria pichoniana. Segundo o modelo, o processo de aprendizagem ocorre tanto no ambiente familiar quanto em outras instituições e respondem a um modo de relação social. Nas ideias pichonianas, aprende-se através da experiência, ou seja, a experiência opera como ponto de partida e, de alguma maneira, como ponto de chegada de um processo de aprendizagem (Sâmea, 2002, p. 28). Portanto, a experiência seria crucial no processo de aprendizagem, como forma de apropriar-se da realidade.

Entretanto, promover experiências no campo da aquisição de conhecimento e das trocas afetivas pareceu ser um grande desafio, pois o que predominava era a passividade diante da figura do coordenador, a falta de questionamentos e críticas com relação à participação no grupo e com a própria condição de vida. Estávamos diante de sujeitos que sempre foram considerados incapazes para aprender e que, na sua grande maioria, não tiveram experiências formais de aprendizagem.

Como provocá-los diante de tanta passividade? Sempre corríamos o risco de sermos autoritários, de atropelarmos seus ritmos com ideias e propostas que eles pouco compreendiam ou questionavam. A ansiedade do coordenador deve ser levada em conta, já que, neste momento, havia um grande desejo de que o grupo se 
desenvolvesse, de que as pessoas aderissem à proposta e não se sentissem ameaçadas com tantos impasses e responsabilidades.

Os momentos de aquisição de conhecimento ocorreram tanto no âmbito coletivo quanto individual. O aprendizado de determinada habilidade ocorre na presença do outro, que ensina e também aprende, numa relação dialética.

No início do grupo apresentei a Beto $(38)^{21}$ um móbile construído a partir de dobraduras de pássaro tsuru. Orientei quanto ao modo de construção e Beto e ACS passaram a realizar esta atividade. O interesse contagiou outras pessoas e a terapeuta S. e outra agente de saúde passaram a realizar a dobradura. Ouvi a estagiária contando aos demais participantes sobre a lenda do pássaro tsuru e complementei a informação, dizendo que era um pássaro que simbolizava saúde, longevidade e fortuna, sendo necessário confeccionar mil destes origamis para ter um pedido atendido. Todos levaram um móbile para casa. Foi um momento de experimentar outra atividade e entrar em contato com outra cultura (sétimo encontro).

Em outra situação na qual desejávamos compreender as experiências dos participantes, perguntamos se alguém conhecia o centro comercial de São Paulo, a R. Vinte e Cinco de Março, e Osmar respondeu: é lá que vende cadernos? Osmar não frequenta escola, não utiliza cadernos, mas como todo paulistano já ouviu falar neste local da cidade. Assim, esclarecemos onde os materiais de bijuterias foram adquiridos, e os apresentamos aos participantes, que se mostraram estimulados e desejosos em realizar a atividade.

As estagiárias apresentaram ao grupo o material que foi comprado no centro da cidade. Esclareci sobre a origem do dinheiro (remuneração do Sistema de Único de Saúde, referente ao pagamento das atividades assistenciais realizadas no âmbito do ensino). A estagiária informou sobre o valor de cada material, das peças mais baratas às mais custosas $e$ sobre a necessidade de utilizar com moderação todo o material. Os participantes apreciaram o material e mostraram-se excitados em iniciar os trabalhos de hoje. Por diversas vezes Osmar questionou: comprou a cola? Antes do início da confecção das

\footnotetext{
${ }^{21}$ Beto, 38 anos, trabalhou como assistente de câmera em emissora de televisão, porém a dependência química o afastou do trabalho. Hoje Beto vive em domicílio situado na cidade de Osasco e sobrevive com o apoio financeiro da mãe e com a venda de ovos e latas de alumínio recicladas. Participou do grupo de convivência em quatro encontros. Foi sua a ideia de chamar o grupo de "Vida Nova”, pois, segundo ele, sua vida mudou após ter conhecido a experiência. Beto não compareceu mais ao grupo, e não foi localizado para obtenção de outras informações sobre sua vida.
} 
bijuterias, os participantes auxiliaram na organização do material, o que favoreceu a execução posterior dos trabalhos. (décimo encontro)

Uma das ideias centrais do grupo de convivência era de que cada participante se apropriasse de todo o processo de produção de determinada bijuteria, como um artesão. Nesse sentido, nos inspiramos nas oficinas terapêuticas, citadas por Galleti (2004), nas quais se valoriza a produção como certo aprendizado de ofício, sendo importante a escolha adequada dos materiais, a combinação entre eles e o uso das ferramentas. Portanto, saber onde se compra o material, quanto custa, como utilizá-lo e como realizar composições harmônicas e bonitas eram questões para serem trabalhadas em cada encontro. Aprender participando foi uma das estratégias utilizadas para promover a aquisição de conhecimentos e habilidades.

Nos primeiros 10 encontros, prevaleceram as relações duais, entre participante e algum profissional. Eram raras outras trocas entre eles e acreditamos que a organização do encontro e as características das pessoas promoviam este tipo de relação interpessoal: a chegada constante de novos integrantes; a presença de uma equipe de apoio numerosa, composta por aproximadamente seis profissionais e estagiários; a presença de pessoas muito dependentes, que necessitavam de apoio direto, o perfil dos participantes que normalmente verbalizam pouco e o anseio por realizar a atividade. Neste cenário, nos perguntávamos: como promover momentos de trocas e conversas mais coletivas entre os participantes, sem que elas fossem artificialmente produzidas?

No décimo encontro, recebemos a presença de Pedro, 24 anos. Compareceu por indicação de Tia Mia, mostrou-se comunicativo, revelou ser vendedor de cosméticos e realizou a confecção de bijuterias com independência e autonomia. 
Escreveu seus dados pessoais num papel e nos entregou. Neste momento pensei: qual a demanda de Pedro? Tia Mia revelou suas percepções sobre ele:

Para Tia Mia, Pedro possui alguma fragilidade psíquica e uma situação cotidiana de poucas atividades que justificaria sua participação num grupo de convivência. Ao me contar o caso, enfatizou que Pedro utiliza medicamentos psiquiátricos, não dorme à noite e mostrase muito agitado. É agredido fisicamente pelo irmão, que o considera preguiçoso. Segundo ela, se não fosse pelo esforço da mãe em cuidar dele, não sei o que seria dele (sic) (décimo encontro).

Não sabíamos sobre as motivações de Pedro em participar, porém pensamos na importância da presença dele num grupo de convivência no qual grande parte dos participantes é muito dependente. A presença de uma pessoa com maior grau de autonomia e expressão verbal poderia ser um estímulo positivo para os demais participantes. Quanto a Pedro, parecia gostar de participar, contar histórias engraçadas e mostrava-se prestativo quando solicitávamos algum apoio.

Hoje (após três meses de atividade), a tarefa do grupo foi definir preços das peças para posterior venda. Chamei a atenção de todos para a tarefa e estagiárias e agentes de saúde opinam mais ativamente. Marisa, Osmar, Adriano e Alice acompanham a situação passivamente. Como será, para cada um deles, a compreensão do valor monetário das coisas? Sei que poucos possuem a experiência do manuseio do dinheiro em seu cotidiano, sendo a tarefa de atribuir preço, inédita para eles. Porém tem sido importante inseri-los em todas as etapas de produção da bijuteria, inclusive no momento da venda. Simplificar a informação e prepará-los para que, paulatinamente, compreendam alguns conceitos, tem sido uma das estratégias de intervenção. Neste processo, ainda estamos observando as habilidades e competências de cada sujeito. Percebo, por exemplo, que Pedro opina mais, possui mais crítica e parâmetros para resolução de questões colocadas no grupo (décimo segundo encontro).

O grupo é aberto não só para a entrada de novos integrantes, como também para participação da comunidade, que comparece ao centro comunitário em busca de informações e auxílio. A porta da sala permanece aberta e provoca curiosidade nas pessoas. O enquadre, que pode ser modificado a qualquer momento, sofreu uma intervenção de uma moradora do bairro, que, ao avistar Osmar: 
(...) o chamou de "tonto". Osmar mostrou-lhe um colar que havia feito, dizendo: esse vale dez reais! A mulher por sua vez, desqualificou o trabalho e novamente num tom jocoso pegou uma tampinha de refrigerante e ofereceu em troca do colar. Não sei como Osmar compreendeu esta situação e penso que este tipo de contato seja frequente em seu dia a dia. Permaneci perplexa e, diante do ocorrido, não consegui reagir. Acredito que aqueles que observaram a cena a consideraram uma brincadeira. Eu não (décimo terceiro encontro).

Esta comunicação soou como um ruído. Qual o valor que a comunidade atribui a Osmar? O que ele produz só tem valor de uma sucata? Qual o valor da produção de uma pessoa com deficiência mental? Foi uma brincadeira que revelou uma das facetas presentes na relação social que se estabelece com a diversidade humana: o desvalor social. Nesta experiência comunitária estas questões apareceram, sem preâmbulos e sem delicadeza. Como será possível um sujeito aprender se não são reconhecidas suas habilidades?

Pretendemos sensibilizar a comunidade, dando visibilidade ao trabalho, às dificuldades enfrentadas pelas pessoas com deficiência, bem como apresentar suas potencialidades e seus direitos. Sintonizado com esta questão, Padre Milton verbalizou que gostaria de apresentar as peças de bijuterias produzidas por Marisa na missa dominical, como um exemplo a ser divulgado para comunidade. Marisa compareceu à missa algumas vezes, e com apoio de Tia Mia, acompanhou a exposição e a venda das bijuterias após as cerimônias religiosas.

Sabemos que o processo de aprendizagem está vinculado às experiências objetivas e subjetivas do sujeito. Aprender depende de uma disposição afetiva, biológica e social, que possibilita ao sujeito a problematização dos modelos internalizados que levem a rupturas e transformações (Sâmea, 2002). Para a autora, inspirada nas idéias pichonianas, “em todos os processos educativos e socializadores (...) incorpora-se, além de um conteúdo, modelos, matrizes, formas de encontro dos 
sujeitos com o mundo, do sujeito com outro sujeito e do sujeito consigo mesmo" (2002, p. 61)

Nesse sentido, promover aprendizado a um grupo de pessoas que tem seus direitos desrespeitados em diversos aspectos da vida, como locomoção, proteção à família, acesso ao trabalho, educação, lazer, cultura, saúde, alimentação, habitação, entre outros, tornou-se um grande desafio. Em alguns momentos do grupo de convivência, nos deparamos com diversas situações nas quais o cuidado tornou-se algo essencial para promover a participação da pessoa. A partir da promoção de cuidado, sustentada por processos vinculares, é que conseguimos promover algum grau de participação e autonomia dos sujeitos assistidos no projeto.

Osmar perguntou sobre o café da tarde e disse que estava com fome. Verbalizou que não se alimentou e isto chamou a atenção da estagiária, que questionou se algo poderia ser feito. Diante da situação, resolvemos organizar um lanche para todos, caracterizando algo coletivo. A fome é algo urgente, não dá para esperar e mobiliza a todos. Porém, oferecer comida afirma a situação de quem pede e continuará pedindo, se transformações em seu cotidiano não forem realizadas. Osmar é reconhecido por pedir alimentos aos moradores do bairro e isto também, se reproduz no ambiente do grupo. Neste momento, lembrei-me da visita em seu domicilio na semana passada, quando, ao ver a cozinha, sem equipamentos $e$ utensílios, pensei se haveria condição de realizar algum tipo de refeição naquele local (sétimo encontro).

Acreditamos que, em diversos momentos do grupo, o cuidado esteve presente: realizamos visitas domiciliares para sensibilizar os sujeitos para participar do grupo, buscamos as pessoas com dificuldade de locomoção, ajudamos a realizar uma determinada ação, oferecemos escuta, buscamos apoio na comunidade e até mesmo provemos alimento, no caso de a fome insistir no momento do grupo.

Autores da reabilitação psicossocial afirmam que, no cotidiano dos serviços, profissionais mostram-se engajados em experimentar novas tecnologias pautadas na noção de cuidado ao sujeito de necessidades, de desejos e crenças (Barros et al., 
2007). Para tanto é fundamental refletirmos sobre o sentido do cuidado, que privilegia o diálogo e a utilização de estratégias criativas que promovam algum grau de autonomia nos sujeitos assistidos.

Cuidar é diferente de tratar. Acredita-se que a medicina moderna, embasada nas pesquisas científicas empíricas, prioriza ações curativas que tratam objetivamente a doença e a deficiência. Cuidar significa, para além dos cuidados clínicos, considerar também os aspectos da manutenção da vida cotidiana do sujeito, suas demandas e necessidades (Barros et al., 2007).

Cuidar é mais que um ato; é uma atitude. Portanto, abrange mais que um momento de atenção, de zelo e de desvelo. Representa uma atitude de ocupação, preocupação, de responsabilidade e de envolvimento afetivo com o outro (Boff, 2008, p. 33).

Para o autor, sem o cuidado, o sujeito deixa de ser humano. O cuidado deve estar presente em tudo, portanto é um fator existencial para a humanidade: o cuidado possibilita a existência humana enquanto humana (Boff, 2008).

No grupo de convivência, o momento de realizar o trabalho corporal constituiu-se um dos momentos de cuidar do outro. Nos primeiros encontros observamos sujeitos envergonhados diante da tarefa inédita de cuidar tão explicitamente do outro, perguntar onde havia dores e se o toque estava muito intenso. Por fim, este trabalho se revelou essencial para os sujeitos que, antes de tudo, solicitam: e a massagem?

Hoje observei Antonia (54) triste e resistente a receber a massagem. Ela disse que depois que ficou assim (depois dos AVEs), não sentia mais dor de nada. Mesmo assim insisti, fiz uma massagem bem caprichada, com sentimento de quem cuida e ao fim, recebi um sorriso de satisfação. Sua presença me faz pensar na importância deste espaço social para ela. Antonia mostrou-se mais alegre e estava empolgada com sua produção de biju. Em momentos em que os jovens do grupo faziam alguma observação engraçada ela ria, com 
intensidade. No momento de decidir os preços das peças foi uma das que mais opinou (vigésimo terceiro encontro).

O cuidado significa ter zelo, oferecer atenção ao outro. Também pode provocar preocupação, inquietação e sentido de responsabilidade (Boff, 2008). A negação do cuidado pela família, pelo Estado, que priva os sujeitos dos direitos fundamentais, causa inquietação em nossa equipe. Percebemos que o descuido foi muitas vezes banalizado e incorporado naturalmente no cotidiano das pessoas que freqüentam o grupo.

Osmar estava enfermo, tossiu muito. Fiquei preocupada com sua saúde, já que sabia das condições precárias de vida: alimentação ruim, moradia com falta de iluminação, ventilação, higiene e presença de mofo. Neste dia estive mais próxima dele e me vi como uma cuidadora: ofereci água, o apoiei durante a realização da atividade. Servi o café e o suco, após ele pedir "por favor" em tom de brincadeira. Refleti sobre o meu empenho em oferecer cuidado, talvez em contraposição ao descuido que suponho ocorrer em sua família (décimo quinto encontro).

Oferecer cuidado revela a dimensão do feminino no homem e na mulher (Boff, 2008). Nossa equipe é constituída por mulheres: estagiárias, agentes de saúde, terapeutas ocupacionais, enfermeira, voluntárias, como Tia Mia, que leva o lanche e assim cuida de todos nós. Consideramos também as famílias, na grande maioria matriarcais, nas quais as mulheres, mães, irmãs e filhas são as cuidadoras das pessoas com deficiência. Cuidar de quem cuida também foi um dos focos de nosso trabalho, que se deu nas visitas domiciliares, nos encontros ocasionais pela rua, no centro comunitário que, com a nossa presença, constituiu-se como uma extensão da unidade de saúde. As famílias sabiam que, quando necessitassem de nosso apoio, poderiam nos encontrar naquele determinado espaço e obteriam alguma escuta de suas angústias e demandas. 
Carmelita, mãe de Kelly (27), moça com deficiência mental, em conversa conosco, revelou que seu neto, Gustavo, apresenta dificuldades no aprendizado e é bastante inquieto, sendo necessária avaliação psicológica. Relatou também que sua outra filha, mãe de Gustavo, também tem dificuldades para aprender. Compreendi este relato como um pedido de ajuda e disse que discutiria o caso com a psicóloga da UBS, para realizar algum encaminhamento. Acredito que nossa presença na comunidade seja um prolongamento da UBS no bairro $e$ pode constituir a rede de apoio de famílias em situação de sofrimento (vigésimo primeiro encontro).

Em outra situação:

A ACS Paula relatou-nos que, segundo a médica da área, havia uma suspeita de câncer de mama em Marisa (46), já informada à família. Entrei em contato com Ana (57), irmã de Marisa, que em sua ausência, nos relatou suas preocupações com relação à saúde da irmã e a dificuldade de realizar os exames necessários. Encaminhada para a Santa Casa de São Paulo, recebeu a informação de que deveria comparecer ao serviço de madrugada, pois o atendimento seria realizado por ordem de chegada. Observei Ana aflita, dizendo: "Como levarei Marisa?" Conversamos sobre a importância de ser confirmado ou não o diagnóstico. Ana aguardou minhas orientações para se dirigir à Santa Casa. (...) Discuti o caso com a médica da equipe, que elaborou uma carta relatando as dificuldades motoras $e$ cognitivas da paciente e a necessidade de atendimento preferencial na Santa Casa (vigésimo quarto encontro).

Nessas duas situações, percebemos a intensidade da responsabilidade e do sofrimento de cada mulher, seja mãe, irmã ou avó. São exemplos de mulheres que sofrem, não apenas pelos cuidados que o familiar com deficiência necessita, mas também pela solidão ao enfrentarem as situações familiares.

Observamos que grande parte das pessoas com deficiência tem sua rede de apoio social restrita à família nuclear, com reduzida citação da família expandida, dos amigos, dos vizinhos e dos equipamentos sociais.

O apoio social fornecido pelas redes formais e informais (serviços públicos, associações comunitárias, igrejas, familiares, vizinhos, amigos entre outros) favorece positivamente as condições de vida dos sujeitos. Ter apoio social significa compartilhar informações, obter auxílio nos momentos de crise, participar de eventos sociais com repercussões positivas no aspecto psicossocial como a melhoria da 
autoestima, da confiança pessoal, bem como benefícios no campo da saúde física e mental (Andrade; Vaitsman, 2002). As redes de apoio social podem estar fragilizadas no caso da presença de familiares com enfermidades crônicas, pessoas com alto grau de dependência, como é o caso de alguns dos entrevistados deste estudo. Segundo Sluski (1995), a desvitalização das relações interpessoais pode produzir um círculo vicioso, no qual a presença de doença ou deficiência afeta, negativamente, a rede de apoio do sujeito, o que, por sua vez, terá um impacto negativo na saúde do sujeito e dos familiares, o que promove a retração e a fragilidade gradual da rede de apoio.

O auxílio à pessoa com deficiência é tarefa realizada, geralmente, por um familiar, na maioria das vezes do sexo feminino, e que desempenha as atividades sem o auxílio de ninguém. Karsh (2003) e Mazza (2005) discutiram o perfil daqueles que cuidam de idosos dependentes, existindo correlação com as características dos cuidadores abordados neste estudo. As famílias encontradas, em grande parte monoparentais ou com outro tipo de organização, têm na mulher um papel importante de liderança e sustento da família.

Portanto, nestas famílias, destaca-se a figura da cuidadora. Todas do sexo feminino, algumas idosas, referindo problemas de estresse emocional e problemas de saúde, colocando em risco sua capacidade funcional. Tal condição é marcada pela impossibilidade de revezar este papel com outros familiares; em alguns casos observou-se uma relação de dependência criada entre cuidador e aquele que é cuidado, numa complementação dos papéis familiares muito estruturados. A cuidadora, assim como a pessoa com deficiência, também vive uma situação de isolamento domiciliar, de adiamento constante de projetos de vida, tendo como justificativa o cuidado da pessoa com deficiência. O encontro destas situações aponta 
para a importância de dar visibilidade a esta personagem e implementar discussões e ações que considerem o sofrimento dos familiares e a constituição de redes de apoio, que sustentem um cotidiano com menor grau de sofrimento para os envolvidos.

Fomos solicitados a intermediar situações de conflito no domicílio e realizamos reuniões familiares nas quais a pessoa com deficiência e demais membros eram convidados a falar, experiência inédita e muito rica para os envolvidos:

Em reunião familiar, onde estavam terapeutas, Marisa (46) e sua família, Ana (57), negou a existência de agressões e disse estar muito cansada com os cuidados da irmã. Disse que não aceita que Marisa diga aos outros que é maltratada. Quando é contrariada, Marisa grita e agride fisicamente os familiares. Pedimos para que Marisa se colocasse. Ela disse que não tinha nada (sic). Falou pouco e chorou muito. Disse que fica nervosa porque não gosta de ficar sozinha (sic)! Insistimos para que ela verbalizasse mais e ela apenas conseguiu dizer: "não vou fazer mais não!

Conversamos com a família enfatizando a importância de que Marisa seja estimulada a verbalizar sobre suas necessidades e que diálogos possam ser realizados. Desta forma pretende-se que ela tenha atitudes mais maduras e que não necessite utilizar recursos como gritar e agredir para se manifestar (...). Promover situações de maior independência são fundamentais para a melhora da condição de Marisa e menor sobrecarga dos cuidadores (trigésimo primeiro encontro).

As interlocuções entre a equipe e os familiares foram de diversas ordens: cobramos responsabilidades, pactuamos compromissos, solicitamos auxílio para a equipe de saúde, produzimos cuidados, oferecemos escuta e aprendemos sobre diferentes modos de gerir a vida. Muitas vezes fomos cúmplices de situações de intenso sofrimento por parte dos familiares e nos sentimos impotentes diante da dificuldade de superar limites e buscar soluções. Outras vezes nos perguntávamos: e a rede de apoio? Com quem ou com quais serviços pode-se contar? Nesse sentido, acreditamos que o grupo de convivência pode compor a rede de apoio social destas famílias, promovendo cuidado, sensibilizando a comunidade para atitudes mais solidárias, articulando recursos existentes e fortalecendo os sujeitos quanto aos seus direitos. 


\subsubsection{O grupo como facilitador de processos de comunicação e de estabelecimento de vínculos}

(...)Osmar compareceu ao grupo muito desorganizado. A estagiária Camila relatou que o jovem foi rude com ela, gestual e verbalmente. Provocou-a dizendo que Camila "não fazia nada certo" (sic) e agiu de modo autoritário. Ainda segundo ela, ele referiu conteúdos sexuais, tocou em suas pernas, segurou firme seu braço... Contatos inéditos no ambiente grupal.

Verbalizou que dormiu "em cima do irmão". A estagiária solicitou mais informações, sobre o que havia acontecido (com quem dormiu? sentiu dor? foi machucado?), Osmar verbalizou diversas vezes: eu sou virgem mesmo, e daí? (vigésimo quarto encontro).

Estas comunicações se deram nas relações duais, que predominaram durante quase todo o período do estudo. Vinculado aos terapeutas e às estagiárias, Osmar, que segundo a mãe, fala muito pouco em casa (sic), verbalizou no grupo questões importantes, que o incomodavam e revelavam conteúdos conflitantes, difíceis de serem verbalizados e compreendidos pelo interlocutor.

Osmar, na relação com a estagiária, a tratou de modo hostil: Camila não faz nada certo! Numa situação inédita, tocou em sua perna e segurou seu braço com intensidade. Na relação transferencial, Osmar talvez tenha projetado em Camila diversas figuras: a mãe que pune, a mulher que provoca atração e desejo. Sentimentos legítimos e confusos, expressos de forma espontânea. Quando se mostra muito imperativo, talvez esteja reproduzindo as relações estabelecidas no ambiente domiciliar e comunitário, nas quais é sempre mandado e precisa obedecer. No grupo de convivência, questionamos seu comportamento, enfatizando a necessidade de estabelecer relações sociais pautadas no respeito e na solidariedade. Acreditamos que este seja um momento de aprendizado e melhoria das condições de sociabilidade.

Segundo Sâmea (2002), as dificuldades de comunicação são inevitáveis. Sentimentos como a ansiedade provocam perturbações na comunicação, 
descontinuidades, mudanças abruptas no tema, silêncios, entre outras reações. Para a autora, estes fenômenos devem ser assinalados ou interpretados para serem explicitados, uma vez que podem influenciar negativamente o andamento do grupo.

Desde os primeiros encontros, os diálogos coletivos entre os participantes eram raros e, por vezes, foram incentivados por nós, terapeutas. Solicitávamos opiniões, introduzíamos alguns temas (por exemplo, a discussão sobre a venda das bijuterias em um evento local), procurávamos coletivizar assuntos discutidos em pequenos grupos, incentivando a coesão e o sentimento de pertinência dos sujeitos no grupo. Porém, a comunicação verbal não parecia ser o modo de expressão mais evocado. Estávamos atentos aos gestos, às expressões faciais, às falas confusas e repetitivas de alguns dos sujeitos e até mesmo o silêncio era interpretado: ora como momento de concentração de todos diante da atividade, ora como resistência em se declarar diante de alguma questão colocada ao grupo.

O silêncio deu lugar às expressões eufóricas com a chegada de um novo integrante no grupo, Yago, 17 anos, jovem psicótico:

Compareceu ao grupo na companhia de estagiária. Utilizaram transporte coletivo para chegar até o local. (...) Apresentando excitação psicomotora, Yago revezou entre realizar uma bijuteria e permanecer junto às crianças. Interessou-se em produzir um colar e neste momento permaneceu bastante concentrado. Ele foi bem acolhido pelo grupo, logo os participantes perceberam o seu jeito particular de se expressar e alguns acharam graça de algumas de suas atitudes. Segundo estagiária, Osmar perguntou: O que ele tem? Yago causou incômodo à Adriano quando passou a cobiçar as peças que ele utilizava na confecção de sua bijuteria (eram diamantes, segundo Yago). Adriano, que sempre se mostra muito concentrado na atividade, manteve uma expressão de desaprovação diante do comportamento de Yago. A estagiária intermediou estas situações, procurando estabelecer acordos para que ele permanecesse no local. O jovem logo percebeu que eu era a coordenadora do grupo e se dirigiu a mim para pedir os "diamantes" de Adriano (décimo oitavo encontro).

Esmeralda, Janaína e Marisa murmuravam expressões de censura e desaprovação. Porém, não se dirigiram diretamente a Yago, talvez aguardando uma intervenção do terapeuta. Eu não reagi, apostando na condição da estagiária em lidar com Yago. Ele se tranquilizou (como ocorre em todos os encontros). Refleti sobre a reação do grupo frente às verbalizações e gestos eróticos produzidos por Yago: as mulheres reagem com censura, 
porém os homens do grupo "acham graça" de suas colocações. Talvez Yago verbalize, sem censura, o que os homens do grupo desejariam expressar: o desejo de se relacionar afetivamente com as estagiárias e terapeutas do grupo (vigésimo primeiro encontro).

Hoje Yago foi mais explícito nas suas verbalizações e desenhos sobre sexo. Percebo que o grupo ainda reage "achando graça" de tudo que ele faz. Stella disse que, para ajudá-lo, era importante não evidenciá-lo e não dar tanta atenção ao seu comportamento exibicionista. Foi conversado que quando alguém se sentisse incomodado com alguma atitude, isto poderia ser verbalizado diretamente a ele. Era importante considerar os sentimentos dos demais participantes, não tratar Yago nem com indiferença, nem com hostilidade. Mas sim através de um diálogo que promovesse o amadurecimento dos envolvidos (vigésimo terceiro encontro).

A presença de Yago no grupo de convivência foi uma alternativa para a falta de assistência do jovem. Diante de tantas respostas negativas com relação à inserção em serviços de educação, pensamos na importância de acolhê-lo no grupo. Sua frequência tem refletido na dinâmica do próprio grupo de convivência, que diante de suas reações descontínuas, conteúdos eróticos e bem humorados, provocou sentimentos e comportamentos inéditos nos participantes, como os já descritos.

O início da participação de outra jovem, Janaína, 16 anos, também foi marcante para o grupo, principalmente no que se refere à comunicação, já que ela é bastante expansiva e bem humorada. A partir do décimo nono encontro, após a entrada de Yago e Janaína, observamos cenas de maior interação entre os participantes. Numa das situações, Janaína, ao ver Osmar irritar-se com a estagiária, verbalizou: Osmar, você não pode pegar no pé dela! E Osmar respondeu: então eu vou pegar no seu! O que rendeu risos no grupo.

A participação de Janaína despertou um sentimento de disputa em Alice, que participava do grupo desde o início dos encontros. Janaína, mais expansiva, expressou seu afeto às estagiárias através de abraços e exclamações, o que provocou ciúmes em Alice: Elas não são só sua... eu as conheci primeiro! (sic) Alice, sempre muito quieta, expôs seus sentimentos e também reivindicou a atenção das estagiárias. 
Talvez este fosse um ensaio para sua vida particular. Sabemos que Alice ocupa um lugar social de desvantagem na família, se comparada à irmã, que estuda e trabalha. Alice necessita reivindicar mais atenção e oportunidades para sua família.

Numa outra cena, Osmar aproximou-se de Yago, chamando-o de cabuloso. Por diversas vezes perguntei: o que é ser cabuloso? Mas eles não respondiam. A sensação que tinha era de que ser cabuloso era algo legal, talvez uma "tribo de jovens” da qual eles participavam. Ambos se identificavam e gostavam de permanecer juntos. Porém, quando Yago extrapolava em comportamentos escandalosos, Osmar impunha limites: Para, Yago, aqui é lugar de trabalhar!

A convivência com as diferenças foi uma tônica dos encontros: como perceber e lidar com as diferenças do outro? Como agir diante das diferenças e também das semelhanças?

Yago seguiu exaltado, pulando e gritando. Achei interessante nenhum participante se colocar. Olhavam, achavam graça. Mas neste dia, Janaína (encorajada pela estagiária) rompeu a indiferença e a excessiva tolerância e pediu para que Yago parasse de gritar. Disse que ouvia muito mais por conta da síndrome que possui e que é assim desde que nasceu. Ele respondeu, afirmando que também era assim desde que nasceu. Yago pediu desculpas. Neste momento, ele pôde ouvir Janaína e se relacionar com ela (vigésimo sexto encontro).

A estratégia de incentivar participação das pessoas nas etapas de produção das bijuterias também promoveu discussões sobre as competências e as diferenças dos participantes.

Propus uma discussão coletiva sobre quem cuidaria do dinheiro do grupo, já que com as vendas após a missa tínhamos uma verba para administrar. Diante da questão, Maura (voluntária) se dispôs a cuidar do dinheiro do grupo. Marisa (46) também se dispôs a ser tesoureira do grupo, porém Esmeralda e Maura questionaram a sua falta de responsabilidade e compreensão para a tarefa. Solicitei que Alice (16) e Adriano (29) contassem o dinheiro arrecadado e ambos demonstraram fragilidades no manuseio do dinheiro. Contas de adição são realizadas com equívocos. Como Adriano lida com sua aposentadoria? (décimo nono encontro) 
Alice e Adriano não sabem fazer contas; Marisa não reconhece os números. Neste momento, as diferenças apareceram e foram comunicadas. Como estas pessoas poderiam participar? Identificamos lacunas e nelas deveríamos trabalhar e buscar estratégias e artifícios para que conceitos e operações matemáticas pudessem ser assimilados. Para tanto, era necessário explicitá-los e colocá-los como problemas a serem equacionados.

As diferenças raciais também foram temas dos encontros. Algo trazido principalmente por Osmar, que dizia: Não tem café? Eu não gosto de leite, não gosto de branco, só de preto, e assim parecia refletir sobre sua própria cor de pele e a compreensão da diferenças raciais. Numa outra situação:

Janaína, assim como Osmar, gosta de tocar nos cabelos das estagiárias. Ela tocou no cabelo da estudante Luana e enfatizou a maciez. Osmar observou a cena e provocou Janaína verbalizando: o cabelo dela (Janaína) é que nem Bom Bril! Num outro momento, no mesmo encontro verbalizou sobre Tia Mia (também negra): ela é preta! Neste momento enfatizamos a Osmar e ao grupo a presença de duas mulheres negras muito bonitas, vaidosas e simpáticas em nosso grupo. Acredito que para Osmar esta é uma forma de expressar e elaborar sua própria identidade. As diferenças raciais têm mobilizado o jovem, por exemplo, quando ele se aproxima de uma pessoa branca e compara a cor dos braços. $O$ grupo, portanto, tem sido um lugar de percepção e elaboração das diferenças raciais (vigésimo terceiro encontro).

Podemos imaginar Osmar ou Yago tocando no braço ou nos cabelos de uma jovem num ponto de ônibus qualquer. Como ela reagiria? Possivelmente, não seria receptiva a esta aproximação. No grupo de convivência, o toque corporal, presente na massagem, é permitido e realizado a partir do estabelecimento de vínculo, o que permite aproximações e comparações.

Yago chama a atenção dos demais participantes verbalizando conteúdos sexuais. Quer abraçar e casar-se com terapeuta e estagiárias. A presença de jovens no grupo (participantes da comunidade, estagiários, terapeutas) também provoca nos 
sujeitos interesses e motivações no âmbito da sexualidade. A chegada das estagiárias, logo no início do semestre, gera expectativas nos participantes do sexo masculino que, perguntam: quando vêm as meninas?

No grupo, as situações de manifestação da sexualidade têm sido freqüentes e consideradas como algo inerente à convivência. Algo sadio, que desperta a admiração pelo outro, provoca sentimentos e emoções (vigésimo oitavo encontro).

Hoje percebi Alice (16) mais solta, mais alegre. Conversou comigo, com as estagiárias e com Pedro (24), que comentou o motivo de seu aparente "assanhamento" (sic): a presença do médico residente no grupo. Alice sorriu e pareceu aceitar a brincadeira do colega (vigésimo oitavo encontro).

Yago iniciou e terminou uma peça e desejou presentear uma menina que estava no centro comunitário. A garota aceitou o colar e um beijo no rosto. Parece que esta situação revelou a Yago outra maneira de se relacionar com as "garotas", que sempre se assustam diante de seus pulos e gritos (vigésimo nono encontro).

Nas entrevistas individuais, solicitamos que os entrevistados falassem sobre os integrantes do grupo e com quais mais se vincularam. Num primeiro momento, Osmar lembrou-se de cinco estagiárias que participaram do grupo: falou os nomes e perguntou onde elas estavam e onde moravam. Recordou-se de fatos envolvendo as estudantes, demonstrou apreço e carinho ao falar delas. Referiu-se também a seus colegas do grupo: Valdomiro (com quem não possui uma relação amistosa: eu não vou sentar perto do Valdomiro!) e Adriano, de quem fala com respeito, já que ele apresentou seu título de eleitor ao grupo, o que chamou a atenção de Osmar, afinal, para ele ter um documento é muito importante.

Já Adriano lembrou-se de Osmar com mágoa. Solicitamos que os homens do grupo auxiliassem Adriano no retorno para casa, empurrando sua cadeira de rodas. Osmar, numa atitude machista, verbalizou que não ajudaria um homem. Para Adriano, referindo-se a Osmar: “magoa muito a gente (...) aquele tipinho dele (...) eu sei que ele não gira muito bem da cabeça, mas magoa também, falando daquelas 
coisas... Para Adriano, os obstáculos para locomoção não favorecem os encontros, e quando se lembra dos demais participantes do grupo, também o faz a partir do contexto da dificuldade de circular pelo bairro.

(...) eles passam aqui (em frente a sua casa): opa! Tudo bom? Tudo bom. O moreno, o Neguinho, esqueci o nome dele... é ...(Valdomiro) ele passa aí, e fala oi, tudo bom, cumprimenta, tudo bom, vai lá embaixo? (no centro comunitário) Ah, se você vim me pegar no colo eu vou... tem que (...) pegar cadeira, se você vir pegar no colo eu vou! Ah, vamo lá, vamo lá, vamo lá... né...(Adriano, 29)

Marisa falou sobre a situação vivenciada por Osmar, que no final de 2007 perdeu-se da mãe na região do litoral de São Paulo e permaneceu desaparecido durante um mês. Após este período foi encontrado num asilo. Marisa mostrou-se muito sensibilizada com o colega, e apresentou sua versão sobre o caso.

Ela demonstrou compaixão ao relatar a situação do colega. Sua compreensão pareceu coincidir com o entendimento que a comunidade produziu sobre este caso, de que Osmar foi vítima do descuido da mãe. Quando se referiu à deficiência do colega evocou o sentimento de piedade e se identificou com esta situação dizendo: nós, deficientes. Marisa também é alvo deste tipo de sentimento, e embora imatura emocionalmente, percebe esta situação.

Quanto às senhoras presentes no grupo, estas sorriem e observam os diálogos e as brincadeiras dos jovens. Antonia e Maria Regina, ambas com sequelas de acidente vascular cerebral, sentam-se próximas, porém trocam poucas palavras e olhares. Mostram-se sempre concentradas com a realização da atividade (ou identificam-se pouco com o conteúdo das conversas dos jovens?). Percebo que há dois grupos distintos, compostos por duas gerações, os jovens e as senhoras. O encontro é rico, pois promove a aproximação de sujeitos com experiências distintas, porém existem diferenças quanto às necessidades, interesses e motivações. 
É interessante observar que o número de senhoras vem aumentando no grupo: Celeste (80), Antonia (54), Maria Regina (57) e Esmeralda (68).

Mostram-se concentradas na confecção de bijuterias e, quase não conversam entre si. Algumas apresentam dificuldade de visão (Celeste e Antonia), outras dificuldades motoras (Antonia e Maria Regina), o que torna importante realizar adaptações (lupas com suporte e agulhas que facilitam a colocação do fio através da conta) e oferecer ajuda pessoal para que realizem a atividade. Mostram-se satisfeitas em realizar a atividade e gostam de utilizar as bijuterias que produzem. Antonia verbalizou: meu colar está ficando lindo! Ela, que sempre se mostra tão triste, pode se alegrar diante de algo que ela mesma pode produzir! (vigésimo sétimo encontro)

Para Zimmerman e Osório (1997), o tamanho de um grupo não pode exceder sua capacidade de comunicação, tanto verbal quanto auditiva. Na experiência do Grupo de Convivência Vida Nova, a comunicação operou de modo singular. A heterogeneidade (referente ao tipo de deficiência, idade e sexo), o número de participantes (que oscilou entre 6 e 14) e a entrada permanente de novos integrantes e a saída de outros foram fatores que influenciaram a formação de vínculos e a comunicação do grupo.

Observamos as conversas coletivas, incentivadas pelos terapeutas e pelos participantes mais comunicativos, as conversas duais ou em pequenos grupos, os ruídos, as repetições, o silêncio e também a aceitação passiva daquilo que o coordenador discutia como proposta.

Porém, ao longo da experiência, observamos mudanças positivas na comunicação dos participantes, proporcionadas pelos processos vinculares e pela maior coesão do grupo. Fatores relacionados à coesão, como a satisfação pessoal e o desejo individual de participar (Maximino, 2001), estavam presentes e operantes no grupo. Percebíamos que os participantes esperavam ansiosamente pelo dia do encontro, o que foi expresso nos depoimentos e demonstrado através do comportamento daqueles que compareciam mais cedo ao grupo e resistiam para ir 
embora, como era caso de Osmar e Pedro, que sempre diziam que o tempo era insuficiente para realizar suas bijuterias.

Como discutido por Maximino (2001), o grupo de atividades, bem como a instalação de um clima de bom humor, facilitou as relações interpessoais, em comparação com as dos grupos verbais, interferindo positivamente no grau de comunicação entre os sujeitos.

O grupo de convivência também estabeleceu uma comunicação com seu entorno. Almeida et al. (2004) discutem a oficina terapêutica no âmbito da saúde mental. Esta seria um dispositivo com capacidade de criar intercâmbios, trocas, com o espaço do fora, da comunidade, da cidade, de fazer intercâmbios com tudo que não pertence ao espaço de dentro, seja através da circulação dos produtos, seja pela socialização dos participantes em espaços de trocas interpessoais. Através do grupo, fizemos conexões com o centro comunitário, a comunidade, a unidade de saúde, a subprefeitura e com outros serviços e recursos, procurando romper com a situação de isolamento das pessoas e suas famílias. 


\subsubsection{O grupo como oportunidade de discussão de direitos e circulação social}

Adriano (29) compareceu ao grupo conduzido por Alzira (...). Neste dia verbalizou estar muito insatisfeito com o atendimento prestado pela Atende, pois não está sendo transportado para o grupo Mosaico por equívoco e falta de organização do serviço. Percebo Adriano crítico e questionador diante de situações como esta, na qual o seu direito não tem sido respeitado (décimo segundo encontro).

O convite para participar de uma reunião com o subprefeito da região, para discutir temas referentes à deficiência $e$ as condições do bairro, repercutiu positivamente nos participantes, que desejaram participar do encontro. Esmeralda (68) defendeu a ideia da participação dos moradores neste tipo de reunião e afirmou que muitas pessoas estão isoladas em seus apartamentos. Sob sua condução (neste momento Esmeralda foi porta voz da comunidade), foram discutidos diversos temas, sendo enfatizada a precariedade do transporte coletivo. Eu introduzi o tema sobre a reivindicação da cessão de uso permanente do terreno para centro comunitário (...). A presença de Yago (17) e o questionamento sobre sua frequência em escola promoveu a discussão sobre a inclusão escolar de crianças e jovens com deficiência. Expliquei que, nos dias de hoje, muitas crianças com deficiência tem o direito à escola regular e os auxílios necessários, porém para jovens como Yago, a inclusão escolar se torna mais difícil, pois as escolas têm dificuldade em lidar com jovens com este perfil (psicose e autismo) (décimo oitavo encontro).

Esmeralda, senhora da comunidade foi quem mais participou da reunião de preparação. Os demais apenas observaram e escutaram as nossas colocações. Percebemos que a passividade dos sujeitos está relacionada à falta de experiências comunitárias e também à dificuldade de compreender intelectualmente as situações. Neste sentido, incentivamos a presença de interlocutores, como familiares e outras pessoas moradoras do bairro, que pudessem intermediar a discussão, falar sobre as dificuldades vivenciadas pela comunidade, inclusive pelas pessoas com deficiência.

Mais uma vez acreditamos na participação como forma de aprendizado. Somente desta forma, sendo convocados a participar, pode-se gerar sensibilização, consciência crítica e engajamento social. Adriano tem passado por este processo. Rompeu o isolamento domiciliar, participou de grupos de convivência, conheceu pessoas com deficiências engajadas em movimentos sociais e passou a participar das atividades do conselho municipal da pessoa com deficiência. Embora tenha 
dificuldades de apropriar-se das discussões (a falta da leitura e escrita dificulta o acesso às informações), ele tem exercido sua cidadania, buscando seus direitos sociais: reivindicou o transporte coletivo adaptado, o transporte Atende, a assistência em fisioterapia, a cadeira de rodas adaptada através do sistema único de saúde, o passe livre de ônibus e o título de eleitor, sua mais nova aquisição, que também chamou a atenção de outros colegas do grupo que também desejam votar e participar da vida política.

No encontro entre subprefeito, pessoas com deficiências, familiares e representantes de setores como transporte, saúde e educação, foram debatidos diversos temas, sendo enfatizada a questão da precariedade do transporte adaptado, afinal pouco adianta ter aonde ir, se não há meios de locomoção. Neste dia, as pessoas com deficiência da Cohab Raposo Tavares reuniram-se com demais moradores de outros bairros para discutir e dar visibilidade às problemáticas enfrentadas por esta população. Neste aspecto, nos inspiramos na ideia do exercício da cidadania, difundido pela reabilitação psicossocial. Para Gabbay e Silva (2004), o exercício da cidadania é objeto da construção de um novo lugar para a loucura (podemos dizer, também, para a deficiência?), uma nova identidade e práticas de intervenção diferentes dos saberes tradicionais, pautados na geração de formas de sociabilidade mais justas e igualitárias e respeitando o modo singular de cada sujeito.

Fazer parte de um grupo pode gerar potências nos participantes, já que, ao se relacionarem com outros sujeitos com experiências semelhantes, podem trocar informações, acionar recursos e apoios para lidar com as necessidades da vida cotidiana. 
A participação em passeios e festas também foi uma oportunidade de as pessoas com deficiência circularem socialmente.

Marta, quando vai ser o próximo passeio? Esta é uma indagação muito presente em nossos encontros. Aguardam ansiosos pelo anúncio da próxima saída e opinam sobre os lugares que gostariam de conhecer. Já é uma tradição do projeto: duas vezes ao ano, realizamos passeios para algum local da cidade de São Paulo. Utilizamos transporte coletivo ou o serviço Atende. Pesquisamos locais acessíveis e que não sejam custosos para os participantes.

No Grupo de Convivência Vida Nova esta demanda foi motivada a partir do convite a um passeio que reuniu pessoas com deficiência e familiares envolvidos no projeto de reabilitação com ênfase no território. Experiência rara na vida destas pessoas, as saídas passaram a ser desejadas, sendo que, no período deste estudo, foram realizadas as seguintes atividades externas:

Passeio ao Parque Ecológico do Tietê - abril 2006;

Participação na Festa Junina da UBS Jd. Boa Vista - junho;

Participação na compra de mobiliários para o grupo, em centro comercial da cidade de Osasco, SP - outubro;

Passeio ao cinema - dezembro;

Passeio ao SESC Interlagos - dezembro;

Participação na festa de final de ano da UBS Jd. Boa Vista dezembro.

Estas foram as oportunidades para sair e romper com o isolamento domiciliar durante o período. A riqueza destas experiências se inicia com a organização da atividade, momento no qual discutimos quando, onde e como os passeios serão 
viabilizados. Assim, pretendemos descrever e analisar uma destas experiências, de modo a dimensionar a importância de um passeio na vida dos sujeitos estudados.

Apresentaremos o passeio ao cinema, pois este reuniu apenas os integrantes do Grupo de Convivência Vida Nova. Os demais passeios contaram com a presença de pessoas assistidas pelo projeto de reabilitação com ênfase no território, moradoras de outros bairros, sendo difícil a realização dos registros em diário de campo.

Marisa sugeriu que conversássemos sobre o passeio no cinema, o que recebeu o apoio dos demais participantes. Sugeri que buscássemos um jornal para sabermos qual era a programação da cidade. Um dos estagiários acompanhou Janaína (16), Alice (16) Valdomiro (35) e Yago (17) nesta tarefa. (...). Retornaram ao centro comunitário e foram lidas as informações sobre os filmes: ninguém manifestou preferência. Valdomiro verbalizou gostar de filme de terror e Janaína se opôs a esta escolha. Yago gritou: eu gosto de filme de mulher pelada! Todos riram. Decidimos então discutir outras condições para realizar o passeio: dia, horário, transporte, dinheiro necessário, lanche e autorização dos familiares. Os estagiários encaminhariam uma carta ao cinema, solicitando meia entrada para todos.

Entre os participantes, somente Celeste (80) recusou-se a participar. Os demais se mostraram muito motivados e comentaram sobre a condição financeira:

- Eu ganho mesada... quero comer um lanche lá! (Janaína)

- A Ana cuida do meu dinheiro! Tem que ver com ela (Marisa)

- Alessandra afirmou gestualmente que deseja participar e solicitou meu apoio para pedir permissão à avó. Sei que a religião da família não permite o acesso à televisão e ao cinema. O grupo mostrou-se bastante imaturo e desconcentrado no momento desta discussão. Foi necessário insistir, chamar a atenção, ajudar na compreensão das mensagens. Marcamos a ida para daqui três semanas, o que nos dava tempo para organizarmos melhor esta saída. (trigésimo encontro)

Observamos que, dentre os participantes, apenas Pedro, Janaína, e Antônia lidam com dinheiro em seu cotidiano. Os demais não possuem esta experiência e necessitam de familiares para administrar seus benefícios, como é o caso de Yago, Valdomiro e Marisa.

No encontro seguinte, retomamos a discussão. A questão da falta de recursos financeiros foi a tônica das conversas.

Valdomiro não tem certeza se participará. Diz que o problema é o dinheiro, pois sua família precisa reformar a casa. Diz que o dinheiro é para comer e vestir. Percebo que Valdomiro participa de alguma forma da discussão sobre o uso do dinheiro da família, embora não 
administre a pensão deixada pelo pai, não tendo nenhum acesso a este recurso (trigésimo primeiro encontro).

Diante do problema, não houve manifestação por parte dos demais participantes. Será que aguardavam das coordenadoras uma solução? Lancei uma proposta para que todos participassem: o uso do dinheiro do grupo para pagar as despesas daqueles que não poderiam custear o ingresso do cinema e o pagamento do lanche para todos. Eles concordaram, embora apresentem dificuldades importantes na compreensão das propostas. Antônia foi auxiliada por estagiária a contar o dinheiro do grupo. Havia um montante razoável para o pagamento das despesas. Antônia verbalizou que, sendo assim, iria ao passeio. Celina (80) foi convencida pelo grupo a participar (trigésimo primeiro encontro).

Ainda restava a discussão com a família de Alice:

Realizei uma visita domiciliar à família de Alice. Sua bisavó mostrou-se muito receptiva e afirmou que a neta poderia ir ao passeio. A nossa atenção e preocupação com a jovem pareceu sensibilizar a avó, que permitiu sem questionamento. Mais tarde pensei se Alice conseguiria negociar seu passeio com a família sem nossa intervenção. Será que intervimos demais? Desta forma estamos promovendo sua autonomia? Talvez uma comunicação por escrito, entregue e discutida por ela, seria uma intermediação mais interessante para o enfrentamento da situação pela jovem? (dúvidas sobre o quanto tutelamos os usuários, o quanto é difícil saber dos nossos limites...) (registro realizado dia 13 de novembro de 2006).

Foram necessários dois encontros para organizarmos a atividade. A discussão, porém, não foi suficiente para garantir a presença das pessoas na data e na hora marcada do passeio. Este foi um dia de muitas intercorrências, imprevistos e reflexões.

Logo que cheguei ao centro comunitário chamou-me a atenção o reduzido número de participantes que conseguiram se organizar para participar do passeio.

Adriano comunicou ao estagiário (que foi buscá-lo em seu domicílio) que havia se esquecido do passeio. Acredito que, para Adriano deslocar-se utilizando cadeira de rodas e ônibus seja algo difícil, considerando os obstáculos e a ajuda necessária para enfrentá-los (...)

Celeste (80) compareceu ao centro comunitário dizendo que não iria, por falta de dinheiro (não compreendeu nossa proposta!). Antonia também compareceu, dizendo que não estava pronta, precisava banhar-se. Neste momento pensei comigo: quanta dificuldade para sair de casa! Conversei com cada uma delas, esclareci sobre o uso do dinheiro do grupo e que esperaríamos por elas. Percebi que o movimento do grupo, que já aguardava no centro comunitário, também foi determinante para contagiá-las positivamente a participarem do passeio. Celeste chegou, com a roupa trocada e um sorriso muito intenso no rosto. Pensei comigo: como registrar estes momentos tão significativos?

Osmar compareceu com atraso, muito alegre e falante, mostrou sua carteira de passe livre de ônibus como se fosse um troféu. 
Pedro (24) parecia abatido e quando questionamos sobre seu estado, ele justificou que havia alterado o tipo de medicação psicotrópica e isto causava sono. Afirmou que, mesmo assim, desejava participar do passeio.

Perdemos o ônibus adaptado. Restou-nos utilizar os carros particulares das terapeutas ocupacionais, o que consideramos negativo, já que desejávamos incentivar o uso de ônibus para acessar os recursos da cidade, de acordo com a realidade da população atendida. Porém foi uma situação "imprevista", e isto também deve estar "previsto" no trabalho (trigésimo terceiro encontro).

Neste momento sentimos a dificuldade objetiva de utilizar o transporte coletivo adaptado. Embora seja eficiente e cômodo, sabemos que existe apenas um veículo adaptado por linha de ônibus e este tem hora certa para passar. Imaginamos o quão difícil é a vida de uma pessoa que utiliza cadeira de rodas e que depende deste tipo de transporte para locomover-se pela cidade.

A falta de transporte adaptado e a presença de barreiras arquitetônicas impediram Adriano de participar desta atividade e de outras, que exigem o seu deslocamento pela região. Neste caso acrescentamos mais uma dificuldade: todas as passarelas existentes na Rodovia Raposo Tavares possuem grades de proteção contra circulação de motoqueiros, o que impede a passagem de cidadãos que utilizam cadeira de rodas. Portanto, o acesso aos recursos da região (parques, centro de convivência, shoppings, lojas, serviços de saúde, escolas) está impossibilitado para pessoas como Adriano, que seguirão impedidos de usufruir estes serviços e recursos.

O cinema estava localizado em um Shopping Center, próximo ao centro comunitário. Maura, voluntária do grupo, impressionou-se com aqueles que nunca haviam frequentado esse ambiente, já que ela era visitante assídua do local, assim como suas amigas de bairro. Muitos também nunca tinham frequentado um cinema. Este local foi escolhido, pois era o mais acessível e possível para a finalidade do passeio. 
Soubemos que o bilheteiro que nos atendeu residia no bairro Cohab Raposo Tavares. Será que o funcionário reconheceu Osmar? Ele comprou seu bilhete com a ajuda da estagiária. Pediu "meia entrada". Situação inédita em sua vida que o possibilitou usufruir de um recurso da cidade. Fomos todos muito bem atendidos pelos funcionários do local (trigésimo terceiro encontro).

No saguão do cinema, o grupo se reuniu para a decisão do filme que seria assistido. As senhoras optaram por um filme sobre o menino Jesus e os jovens, na companhia dos estagiários, assistiram ao desenho "Deu a Louca na Chapeuzinho", uma sátira da história tradicional, ambos dublados. As escolhas pareceram muito assertivas. No momento da saída do cinema observei expressões de satisfação e alegria. Permaneci com o grupo das senhoras, mas tive a oportunidade de ver as fotos tiradas dentro da sala de projeção onde estavam os jovens. O clima era de muita descontração e estagiários relataram que o filme foi assistido em meio a risos e exaltação da plateia (trigésimo terceiro encontro).

Realizamos o lanche, alguns demonstraram excitação e ansiedade diante da presença da comida, que foi partilhada por todos. Em um momento demos conta da falta de Osmar no grupo. Reagimos preocupados; eu e uma estagiária fomos procurá-lo. Após certo tempo vimos Osmar, muito tranqüilo, dirigindo-se para o banheiro. Ficamos "sem jeito" por termos nos precipitado, porém sua falta de experiência neste tipo de ambiente e o temor de que fosse abordado por alguém (por um segurança?) nos deixou em alerta.

Situação semelhante foi vivenciada por Sâmea (2002), que, num passeio, descreveu sua insegurança diante da possibilidade de perda de um participante num espaço público. Em nosso caso também ocorreu o medo de que Osmar se perdesse ou fosse abordado por alguém. Tutelamos demais os participantes? Estávamos desconfortáveis naquele ambiente em meio a lojas e agentes de segurança? Desejamos fomentar oportunidades para maior autonomia dos participantes, porém em momentos como o descrito, surge a insegurança e depois a reflexão sobre as atitudes tomadas. Está aí a riqueza de um passeio.

Tais observações mostram como foi trabalhoso promover este passeio. Quantas discussões e apoios foram necessários para produzir esta saída! O contato com o novo, com o inédito (afinal passear é algo raro na vida dos sujeitos) gerou resistências e o enfrentamento dos obstáculos exigiu nosso apoio (porém não conseguimos transpor as barreiras colocadas à Adriano, que ficou excluído desta experiência). O lazer, muito desejado pelos participantes, também não pôde ser 
usufruído por Valdomiro, que, dias após o passeio, justificou sua falta dizendo que foi trabalhar com o irmão na reforma da casa. Nesse sentido, a importância do trabalho supera a do lazer, como se este fosse uma "perda de tempo". Porém sabemos que não é. O lazer é vital para os seres humanos, sendo uma das esferas mais importantes da vida cotidiana. Quantas situações importantes foram geradas com os sujeitos, com o grupo e também para o ambiente no qual circulamos.

As oportunidades de passear, de frequentar o grupo de convivência realizado no centro comunitário e de circular por outros locais e serviços do bairro (UBS, escola, missa) trazem repercussões para o território. Considerando que este está diretamente articulado aos perfis de seus habitantes, se o cotidiano de um território for habitado regularmente pela convivência entre pessoas com e sem deficiência ou transtorno psíquico, isto talvez promova a provocação de novos olhares e novas vias de sociabilidade (Sâmea, 2002). Acreditamos que a circulação das pessoas com deficiência pelo bairro, pela região, e pela cidade provoquem transformações não apenas nos sujeitos diretamente envolvidos, mas também no entorno: nos familiares, vizinhos, no motorista de ônibus, no funcionário da bilheteria, entre outros, que, a partir da convivência, podem construir relações de respeito e solidariedade.

\subsection{A dimensão de ser terapeuta, coordenador e pesquisador de um grupo}

Um dos desafios deste trabalho foi balizar e articular a figura de coordenador e pesquisador do grupo de convivência, preocupação esta que esteve presente logo nos primeiros registros do diário de campo como fator a ser pensado e cuidado. Para tanto, era necessário termos clareza sobre a função de um coordenador no espaço 
grupal. Para Maximino (2001), que cita os estudos de Fidler, o terapeuta é o líder do grupo:

\begin{abstract}
Sua função é facilitar o processo e criar o melhor ambiente que possa conduzir ao tipo de crescimento e aprendizado para os quais estes grupos estão dirigidos. $\mathrm{O}$ terapeuta não deve assumir responsabilidades em lugar do grupo, mais sim percebê-lo como um agente terapêutico. Suas atitudes devem estar baseadas na crença e no direito do paciente de se autodeterminar e na confiança suficiente para permitir este exercício de liberdade para explorar e testar suas próprias capacidades (p. 33).
\end{abstract}

No cotidiano do grupo, a condição de terapeuta coordenadora sobrepôs a de pesquisadora, que era exercida quando o grupo acabava e, longe da agitação do encontro, podíamos refletir sobre a condição de terapeuta e do grupo. Eram muitas as demandas solicitadas às terapeutas: a realização de visitas domiciliares, a provisão do material necessário para produzir o artesanato, as escutas particulares (das pessoas com deficiência e de familiares), apoio para um e para outro. Marisa solicitava nossa atenção diversas vezes durante um encontro. Osmar repetia as mesmas questões: semana que vem tem grupo? Quando será o passeio? Você já revelou as fotos? Pedidos de atenção, que respondíamos uma, duas, três vezes, pois sabíamos que era importante apaziguar a ansiedade e afirmar que estaríamos ali na semana seguinte. Porém, às vezes, a sensação era de cansaço, físico e mental diante de tantas solicitações.

A coordenação do trabalho envolveu a articulação e produção do encontro, o que extrapolou o momento da realização do grupo propriamente dito. Foram realizadas diversas intervenções, como buscar a pessoa em casa, sensibilizar familiares e a própria pessoa com deficiência sobre a participação no grupo, buscar apoio financeiro para realização das atividades, entre outras que foram necessárias para promover o encontro de pessoas com deficiências na comunidade, onde os 
recursos são reduzidos. Embora contássemos com apoio institucional do centro comunitário (cessão do espaço) e da UBS (participação de profissionais), a coordenação do trabalho permaneceu centrada nos terapeutas ocupacionais.

Considerando a condição das pessoas com deficiência, bem como o ineditismo da experiência, em muitos momentos foi necessário "fazer para”, com a idéia de "construir com" e assim promover a oportunidade do encontro. Facilitamos processos de criação e execução das atividades, incentivamos a comunicação, a relação interpessoal e a produção de situações que gerassem aprendizado e algum grau de autonomia.

Não havia apenas um profissional coordenador do grupo, como é o caso da maioria das experiências apresentadas anteriormente. No grupo de convivência, a coordenação foi compartilhada com outra terapeuta ocupacional, sendo um fator muito importante para o enfrentamento de situações difíceis e aquelas que exigiam uma escuta mais cuidadosa. Nessas ocasiões, uma das terapeutas permanecia no grupo e outra realizava intervenções relacionadas ao caso em particular. Cada terapeuta compareceu com suas habilidades e experiências profissionais e, em particular, Stella, com bom humor e criatividade para propor situações que favoreceram os processos comunicativos. Diversas vezes ela: tocou seu violão, cantamos todos juntos, o que promoveu um ambiente lúdico e acolhedor (quarto encontro).

As discussões de equipe, realizadas logo após o término do encontro, envolvendo os terapeutas, os voluntários e os estagiários, também foram momentos para compartilhar saberes, trocar ideias, integrar a equipe e sintonizar os vários discursos (técnicos e do saber popular) em direção à produção de ideias e atitudes 
mais convergentes diante das situações colocadas. Assim, nas discussões de caso, cada participante contribuiu com suas percepções sobre o grupo, sobre as pessoas com deficiência e sua família. Conversamos sobre as condutas necessárias para alcançar objetivos, as dificuldades percebidas e formas de superá-las. Estas reflexões subsidiaram o modo como coordenamos o grupo e realizamos as diferentes funções atribuídas à coodenação como: planejar, facilitar, ensinar e intervir, conforme definidas por Ballarin (2001).

A função de planejar compreende a constituição do grupo propriamente dito (quem participará, quantas pessoas, qual atividade será realizada), o estabelecimento de contratos para o seu funcionamento e a preparação do ambiente e dos recursos materiais necessários. Nesse aspecto, as terapeutas ocupacionais tiveram um papel de maior destaque, considerando as experiências práticas anteriores na organização de grupos na comunidade. É importante ressaltar que o planejamento dependeu, em parte, da articulação entre terapeutas ocupacionais, recurso comunitário e o apoio de demais profissionais (enfermeira, agentes comunitários de saúde e estagiários). Os recursos humanos disponíveis, considerando os profissionais que gostavam de realizar atividades de artesanato e que estavam disponíveis para ensinar e cuidar, influenciaram a escolha e organização da atividade, bem como a manutenção de um grupo numeroso, aberto e heterogêneo.

A função de facilitar foi descrita e discutida anteriormente nos subitens referentes à promoção de aprendizagem, comunicação e vínculos estabelecidos. Para Ballarin (2001), refere-se a situações nas quais o terapeuta coordenador pode compreender a importância de estar junto, fazer junto, de reconhecer e validar a palavra e a ação do participante e do grupo. Foram diversos momentos, nos quais 
incentivamos as escolhas, as comunicações, apoiamos os projetos de criação e empregamos nossa própria iniciativa para influenciar os demais participantes.

A função de instrumentalizar - ensinar está relacionada com o conhecimento de determinada atividade e a condição de ensiná-la para o outro. Em diversos momentos do grupo, observamos os profissionais e voluntários envolvidos em projetos artesanais particulares, experimentando o potencial das atividades. À equipe é delegada a função de ensinar, tema discutido nas reuniões, nas quais identificamos as lacunas e as potencialidades de cada sujeito e formas possíveis de ensinar. Assim, adaptamos as atividades (uso de lupas e contas maiores), insistimos na ideia de aprender através da participação e enfatizamos o aprendizado de habilidades sociais (dialogar, considerar aspectos da higiene e do vestuário, realizar contatos corporais, entre outras).

A função de coordenar está relacionada às possíveis intervenções do terapeuta, produzidas no grupo e direcionadas a ele, tendo em vista os seus objetivos. Assim, intervir tem o sentido de comunicar-se, colocar-se entre, dirigir-se ao grupo, estar presente nas ações do grupo (Ballarin, 2001, p. 203). Para a autora, que aborda o tema a partir do referencial psicodinâmico, a intervenção junto ao grupo deve considerar os fenômenos transferenciais e contratransferenciais na situação grupal e que ocorrem a partir de processos de identificação projetiva e introjetiva.

Embora nosso objetivo não fosse o de promover um grupo psicoterápico, durante os encontros, esses processos subjetivos e inconscientes estavam presentes na dinâmica grupal e foram considerados na compreensão das situações. Estávamos atentos às falas e ao comportamento de Osmar, que revelavam angústias com relação à família e à sexualidade. A presença de fenômenos contratransferenciais (reações 
inconscientes do terapeuta com relação ao paciente) que geraram tensão às terapeutas ou demais participantes da equipe foram pontuados e discutidos, resultando em manejos que tornassem possíveis a superação de dificuldades e a possibilidade da convivência com as diferenças e modos de vida muito particulares. Assim, foi possível dialogar sobre a relutância da equipe em manter contato com Marisa, que, por sua dificuldade física e intelectual, provocava o desinteresse em acompanhá-la.

Acreditamos que as funções desenvolvidas pelos terapeutas neste grupo foram muito particulares e não se esgotaram na função de coordenar. O encontro necessitava ser produzido. Identificamos problemas, pensamos em alternativas, realizamos encaminhamentos e interlocuções entre as famílias, o centro comunitário e a unidade de saúde.

O que se pretendeu com o estudo foi apresentar elementos para a discussão de uma experiência prática tão singular. Sabemos que muitas atitudes da coordenação poderiam ser questionadas: por que insistir tanto na presença das pessoas? Por que realizar visitas domiciliares aos ausentes e buscar a pessoa com deficiência? Por que um grupo tão heterogêneo e aberto? São diversas questões sobre as quais buscamos refletir neste estudo, e longe de respostas conclusivas, podemos dizer que esta foi a maneira possível de organizar o encontro, pautado no desejo de que ele acontecesse e com a prerrogativa de que o isolamento domiciliar é um fator de risco para a vida das pessoas.

Na tentativa de compreender a experiência, nos deparamos com um campo bastante vasto, que não poderia ser explicado através de uma única disciplina. Assim, buscamos referências nos estudos sobre grupos e percebemos o quão singular era nossa experiência. Dialogamos com alguns dos preceitos básicos sobre o campo 
grupal (aspectos da comunicação, coesão, estabelecimento de vínculos, aprendizagem, presença de fenômenos relacionados ao psiquismo). Porém observamos diferenças no que se refere ao enquadre do grupo.

Aproximamos-nos do estudo da prática das oficinas terapêuticas em saúde mental, desenvolvidas a partir das ideias da reabilitação psicossocial, nas quais reabilitar não significa apenas a reposição de uma perda e, sim, a realização de trocas. Diante das dificuldades e limitações dos sujeitos assistidos, o que deve prevalecer é a dimensão da vida e não somente ações voltadas para a sobrevivência. Esta é uma prática de reabilitação que tem como horizonte o exercício da cidadania (Lobosque; Souza, 2006). Direito de habitar, trabalhar, realizar trocas afetivas e materiais que inscrevam o sujeito em sua comunidade e em sua cidade.

Afirmamos que a convivência é a característica fundamental do grupo, e que ele está distante de uma proposta de geração de renda. Nesta perspectiva, considerando a presença de pessoas com deficiências graves, a prática do terapeuta ocupacional promoveu ações e discussões que fomentaram:

$>$ a construção de apoios para que as pessoas pudessem estar juntas;

o encontro, mediado pela atividade, o que facilitou processos de aprendizagem, de comunicação e de cuidado.

Refletimos sobre alguns dos desafios colocados à proposta: a diversidade do ambiente comunitário, a busca de alternativas para suprir as necessidades materiais, o esforço em se produzir ações que promovessem a autonomia dos sujeitos e o desejo do envolvimento de outros profissionais e familiares na proposta.

Acreditamos que os familiares não foram parceiros na sustentação da experiência e, como discutido, demandaram cuidado e escuta. Embora desejássemos 
que os familiares se envolvessem na proposta (auxiliando na organização dos encontros, participando das discussões), eles não estiveram presentes nestes momentos, talvez pela posição de centralidade, ocupada pelas terapeutas coordenadoras do grupo, o que também pode ser responsável pela diminuição da intensidade da participação dos agentes de saúde. Porém, o grupo era destinado a adultos e promover momentos de desligamento dos sujeitos com relação aos familiares, também era o objetivo da experiência. Era importante compor um espaço de trocas interpessoais para Yago, Kelly, Marisa, Adriano, entre outros, que tinham na família um dos únicos espaços de convivência social.

A experiência assistencial foi construída a partir da escuta das demandas dos usuários, outra premissa considerada neste estudo. Assim, conhecer as atividades cotidianas das pessoas com deficiência que participaram do grupo foi uma forma de aprofundar o conhecimento sobre os diferentes modos de vida dos participantes e refletir sobre o grupo de convivência como parte deste modo de vida. 
5 VIDA COTIDIANA E DEFICIÊNCIA 
Ah, eu fico assistindo televisão, se enjoar de televisão eu fico um pouco ali fora,(...) né, depois, se cansar, venho aqui pra dentro, fico ali na sala, Ali na janela, ali de fora, agora, brincadeira assim, não tenho nenhuma, acho que não tenho nem como ir procurar, né, não tenho... (Adriano, 29).

Dormi bem a noite. (Marisa, 46)

(...) A que horas você acorda todo dia? (pesquisadora)

Hã. Nove horas.

Eu tomo café de manhã, e quando acordo, acordo cedo.

E depois de tomar o café, o que você faz?

(...)Mais nada.

Não faz nada.

Assisto a novela,

Mas a novela é à noite! (...) De manhã você não faz nada, não caminha...

Caminho! Caminho

Você caminha onde?

Aí, lá atrás. Vem aqui, caminho um pouquinho e depois vou lá de novo!

Aí a minha irmã chama eu pra almoçar e eu vou almoçar ........de novo. Vou caminhar.

Então à tarde você caminha. E como é à noite?

À noite? Dormir.

- Eu não faço mais nada, a não ser fumar. Fumar e beber café, só isso. ...E muitas vezes, (...) ficar lá fora, aí o sol começa a esquentar, não posso ficar, por causa da cabeça, aí lá vou eu de novo, volto para sombra, sinto frio, vou pro sol... ai! (fala irritada) O negócio tá quente! Mas ficar dentro de casa tá sendo um caos pra mim(Rosa, 45)

A vida cotidiana é a vida do homem inteiro; ou seja, o homem participa na vida cotidiana com todos os aspectos de sua individualidade, de sua personalidade. Nela, colocam-se "em funcionamento" todos os seus sentidos, todas as suas capacidades intelectuais, suas habilidades manipulativas, seus sentimentos, paixões, idéias, ideologias (Heller, 2008, p. 32).

A vida cotidiana é heterogênea e hierárquica, composta por esferas como trabalho, lazer, vida social, religiosidade, entre outras. O homem vivencia todas estas esferas numa superficialidade fluida, ativa e receptiva que o mobiliza. A hierarquia dada às esferas do cotidiano é mutável e depende da estrutura socioeconômica e dos valores vigentes em determinado momento histórico, que orientam os interesses dos sujeitos em diferentes etapas de sua existência (Carvalho; Paulo Netto, 2007). Para 
Heller (2008), a heterogeneidade e a hierarquia garantem a reprodução da vida cotidiana num movimento simultâneo e rotineiro, garantindo à cotidianidade uma explicitação normal.

O indivíduo é um ser particular e genérico. A particularidade do homem garante sua unicidade, porém não representa a essência da humanidade. A dinâmica da particularidade do homem, segundo Heller (2008), é a satisfação das necessidades do EU, caracterizadas pela necessidade de se alimentar, de sentir e sanar a dor, de amar, dentre outras demandas presentes na cotidianidade dos seres humanos e manifestadas de modo singular para cada sujeito.

O ser genérico também está contido no homem, nas atividades de caráter genérico (como trabalhar), embora a motivação para a realização destas atividades seja particular (Heller, 2008). Assim,

O indivíduo (a individualidade) contém tanto a particularidade quanto o humano-genérico que funciona consciente e inconsciente no homem (...). É comum a toda individualidade a escolha relativamente livre (autônoma) dos elementos genéricos e particulares; mas, nessa formulação, deve-se sublinhar igualmente os termos "relativamente" (...) O homem singular não é pura e simplesmente individuo, no sentido aludido; nas condições da manipulação social e da alienação, ele vai se fragmentando cada vez mais “em seus papéis”(Heller, 2008, p.37).

Portanto, a liberdade e consciência são aspectos essenciais para a elevação do homem à condição humana-genérica. Porém a elevação do indivíduo ao gênero é um fato raro, segundo Heller. A unidade vital entre o particular e o genérico se dá de modo inconsciente e calado, e somente a consciência desta relação é que pode elevar o homem para a condição de inteiramente homem. Somente desta forma rompe-se com a cotidianidade, e o homem pode concentrar todas as suas energias numa atividade humana genérica, na qual investe com autonomia e liberdade. Segundo 
Agnes Heller, o trabalho, a arte, a ciência e a moral ${ }^{22}$ são atividades humanas genéricas, que possibilitam a suspensão da vida cotidiana.

A alienação da vida cotidiana é um tema bastante explorado por Heller. Para a autora, é na cotidianidade que o ser se separa de sua essência:

...o homem devorado por seus "papéis" pode orientar-se na cotidianidade através do simples cumprimento adequado desses "papéis". A assimilação espontânea das normas consuetudinárias dominantes pode converter-se por si mesma em conformismo, na medida em que aquele que as assimila é um indivíduo sem "núcleo"; e a particularidade que aspira a uma "vida boa" sem conflitos reforça ainda mais esse conformismo com a sua fé (Heller, 2008, p.57).

Para a autora, a vida cotidiana não é necessariamente alienada, porém quanto maior for a alienação produzida pela estrutura econômica de uma dada época e sociedade, mais alienado será o cotidiano e as esferas que o compõe. Mesmo na organização capitalista da vida social, o homem encontra brechas para realizar manobras e movimentações que lhe garantam certa autonomia e poder de decisão, sendo possível (mesmo que minimamente) uma retotalização humana que reduz as mutilações provocadas pelo sistema de produção e de consumo (Carvalho e Paulo Netto, 2007). O desenvolvimento do capitalismo moderno acentuou o abismo e as contradições existentes entre o desenvolvimento humano genérico e o desenvolvimento dos indivíduos humanos, bem como entre a produção humanogenérica e a participação consciente do indivíduo nesta produção, criando um cenário progressivo de alienação no cotidiano (Heller, 2008).

\footnotetext{
${ }^{22}$ A moral é compreendida, segundo Heller, como a ética organizada a partir das necessidades sociais. O indivíduo submete sua particularidade ao genérico e a converte em motivação. Uma das funções da moral é a inibição e outra a transformação, a culturalização das aspirações da particularidade individual. A vida cotidiana apresenta alternativas e a escolha estará motivada pela moral. "Quanto maior é a importância da moralidade, do compromisso pessoal, da individualidade e do risco (que vão sempre juntos) na decisão acerca de uma alternativa dada, tanto mais facilmente essa decisão eleva-se acima da cotidianidade e tanto menos se pode falar de uma decisão cotidiana” (2008, p. 39).
} 
A vida cotidiana tem sido foco da produção capitalista de bens de consumo e da atenção do Estado (Carvalho e Paulo Netto, 2007). Na sociedade moderna, o consumo tornou-se imperativo na vida cotidiana dos homens. Nela, o homem se confunde com aquilo que consome, com o que veste, com o carro que possui.

O Estado, através de leis, de políticas públicas, de fiscalizações, do controle das informações, entre outras formas, intervém direta ou indiretamente na vida dos cidadãos. No período do capitalismo pós-guerra, houve forte expansão de suas funções, que passaram a mediar as relações entre o capital e o trabalho, tornando-se agente regulador econômico e social. O Estado Providência passou a assumir funções de reprodução da força de trabalho (promovendo saúde, educação, transporte entre outros), expandiu a demanda de consumo, promoveu maior equidade social e instaurou uma política democrática nos países capitalistas desenvolvidos (Carvalho e Paulo Netto, 2007). Diante deste cenário, discute-se a importância da promoção do desenvolvimento econômico, técnico- científico e a melhoria das condições materiais da classe trabalhadora, porém, com repercussões negativas no que se refere à prática social e a sua vida cotidiana:

O enfraquecimento da classe trabalhadora como sujeito político real; o esvaziamento progressivo do exercício da cidadania; a substituição quase total de um processo de solidariedade espontânea por um processo de solidariedade mecânica emanada do Estado; a perda da visibilidade dos valores essenciais ao desenvolvimento do homem enquanto ser singular e social e, com eles, a perda de referências para a transformação da sociedade (Carvalho e Paulo Netto, 2007, p.35).

Kujawski (1991) discute o tema da crise no cotidiano no século XX e afirma que o homem vivencia esta crise de forma primária e imediata, na qual se rompem as tradições construídas historicamente e o sujeito não reconhece mais o seu contexto, sua comunidade e tudo lhe parece estranho e amorfo: 
(...) a erosão do cotidiano, a prosseguir como está, fará impraticável a realização do projeto individual de vida, por falta de apoio nessa infraestrutura social que é a articulação organizada no cotidiano. (...) A quebra do cotidiano significa nossa ruptura com o contorno, abreviatura do mundo, aquela porção de mundo que alcançamos de imediato; envolve, portanto, nossa radical discrepância com o mundo, nosso estranhamento das coisas, acompanhado da sensação de estarmos perdidos entre elas, desamparados e ao relento (Kujawski, 1991, p.35-6).

Para o autor, a perda do cotidiano está relacionada ao estranhamento do mundo, a sensação de insegurança, a instabilidade para se pensar no futuro. Esses seriam os elementos centrais da crise, caracterizada por uma crise nos fundamentos da vida humana. Kujawski (1991) apresentou as categorias típicas do cotidiano do homem comunal (habitar, trabalhar, conversar, passear e comer), realizou uma articulação funcional do cotidiano e discutiu como a crise vem se instalando nestas instâncias elementares da vida cotidiana. Esta categorização apoiou a discussão sobre o cotidiano das pessoas com deficiência entrevistadas.

Como pensar a vida cotidiana a partir das experiências dos sujeitos entrevistados? O cotidiano é o dia a dia, com a reprodução das mesmas ações. Como diz Adriano, é levantar-se, assistir televisão, ficar dentro e fora da casa. Para Marisa, é acordar, tomar o café da manhã, caminhar, almoçar, assistir à novela e dormir. Adriano revela que brincadeira não tem nenhuma, e Marisa diz que não faz nada.

Apresentado desta forma, o cotidiano destes sujeitos parece sem graça, sem grandes desafios e motivações. Uma vida restrita ao domicílio, distante das experiências humanas, como trabalhar, estudar, namorar, praticar esporte e conversar com os amigos. Porém essas pessoas sobrevivem, projetam expectativas para o futuro e se relacionam socialmente. Relatar um pouco mais sobre a vida cotidiana 
destes sujeitos, que vivem numa comunidade pobre, com possibilidades restritas de usufruir bens materiais e serviços é o desafio deste capítulo.

O cotidiano de pessoas com deficiência física foi objeto de estudo de Almeida (1997), que discutiu a repercussão do processo de reabilitação pautado no modelo médico institucional sobre as ações e relações estabelecidas no cotidiano da pessoa com deficiência. A intervenção clínica focada na promoção do aumento da capacidade funcional pode produzir a alienação dos sujeitos assistidos, que, desapropriados do processo de reabilitação e de seus desejos, são capturados pelos mecanismos sociais de ordenação e controle social. Nesse contexto, os técnicos reabilitariam o paciente para a vida cotidiana, e lhe ensinariam como sobreviver diante das incapacidades. Tais intervenções pouco repercutem na vida real do sujeito reabilitado, que, muitas vezes, retorna à condição do isolamento domiciliar, numa situação de dependência com relação ao cuidador e realização de atividades de automanutenção.

Uma das diferenças entre os sujeitos da pesquisa citada e os entrevistados moradores do bairro Cohab Raposo Tavares é que estes não foram assistidos em reabilitação. Nenhum dos adultos entrevistados passou por processo de reabilitação mais sistemático, pois não responderam aos pré-requisitos para ingresso nos serviços especializados: não possuíam bom prognóstico de recuperação funcional, não possuíam recursos materiais, não tinham transporte nem apoio familiar para manter o atendimento. Embora necessitassem e desejassem esse tipo de assistência, não puderam usufruir dessa possibilidade.

A população estudada, além de possuir a marca da deficiência, também vive a condição de pobreza e restrita participação social. Nesse sentido, a reflexão sobre o 
cotidiano aqui realizada se aproxima das ideias de Lima (1983), que discute a participação social no cotidiano dos grupos populares. De acordo com a autora, o cotidiano destas pessoas é constituído por ações sociais e relações com o sistema; trabalham, reproduzem valores e estabelecem relações sociais diversas. Embora o sistema limite as formas de participação dessa população, esses sujeitos, de alguma forma, marcam a sociedade.

O discurso dos sujeitos entrevistados demonstrou que alimento e moradia são as prioridades do cotidiano pautado na sobrevivência. De acordo com essa hierarquia, as primeiras categorias do cotidiano, citadas por Kujawski (1981) a serem analisadas a partir dos relatos dos entrevistados serão o habitar e o comer.

\subsection{Habitar e comer: a necessidade de manutenção da vida}

Que aí começou a acontecer estas coisas pra mim (a deficiência), aí e eu não consegui mais nada na vida... às vezes eu fico agoniada, fico triste ... porque a gente consegue as coisas $e$ às vezes passa as coisas na minha vida e é nem coisa pra comer, sofri demais. E a filha ganha dinheiro, mas vive com coisas pra pagar, dívida, tudo, e aí por isso que sobra dinheiro do aluguel, e eu pago aluguel, cem real (Antonia, 54).

Eu também não ganho aquela coisa, mas é um fixo, é um trabalho que a gente pode contar, né. Eu pagando o meu aluguel o resto...

Eu sei que eu pagando o meu aluguel eu tenho onde morar, eu pagando, o resto... nem ligo (Cintia, 21 anos, filha de Antonia).

Adriano se recorda das dificuldades enfrentadas pela família em busca de moradia em São Paulo na década de 1980, após terem migrado de Mato Grosso. Narrou a situação de precariedade da família, quanto às condições de moradia: viviam como ciganos em busca de um local para morar, o que foi possível quando o pai passou a trabalhar sistematicamente, com carteira fichada. Fixados num determinado local (ainda que precário, pois era um barraco na beira do córrego), as 
crianças puderam estudar e a mãe, trabalhar. E aí se aquietou, como disse Adriano, a vida cotidiana pôde ser vivida, com suas repetições, assimilações e contradições. No discurso de Adriano, a ênfase dada à busca por moradia pela família parece colocar a habitação num lugar de destaque dentre as outras categorias do cotidiano.

Vivemos a crise da habitação e não há moradias com qualidade para todos. Nas periferias das cidades, muitas famílias vivem em situação precária, como as descritas por Adriano. Famílias perambulam pela cidade como nômades em busca de uma casa para morar e, muitas vezes, colocam em risco a vida e a saúde de seus membros. Nesta condição, os sujeitos perdem suas raízes, o que significa que a forma primária de estar do indivíduo no mundo, não é mais a fixação num lugar e sim o vagar sem descanso e sem destino (Kujawski, 1991). Para Adriano e Marisa, uma das condições que dificultou a realização do tratamento em reabilitação, quando ainda eram crianças, foram as mudanças constantes de moradia e de cidade, o que impossibilitou a realização de um seguimento mais sistemático no campo da saúde e da reabilitação.

Ainda há a condição daqueles que estão em suas casas, mas não as habitam. Para Saraceno (1999), que discute o morar como um dos eixos sobre os quais se constrói a autonomia e a participação da pessoa com sofrimento mental, existem diferenças entre “estar” e "habitar” uma casa. "Estar” está relacionado à escassez de propriedade do espaço pelo indivíduo (tanto material quanto afetiva), enquanto “habitar” é possuir algum grau de propriedade e autonomia neste espaço, tanto material quanto simbólico. Rosa vive uma situação de isolamento restrito ao dormitório. Seu apartamento, como já descrito, mostrou-se desabitado, não há marcas de Rosa pela casa, os armários não possuem utensílios (comida já chega 
pronta da casa de um familiar) e na sala não há mobiliário para sentar, descansar e conversar. A organização da casa de Osmar também chamou nossa atenção pela forma particular de apresentação. Moradia popular, onde vivem dez pessoas que competem pelos mesmos e escassos recursos materiais e afetivos. Osmar divide o quarto com a irmã, onde ele dorme em um sofá. Na cozinha, quase não há sinal de que ali sejam preparados alimentos no dia a dia, e sabemos que O., mesmo sofrendo de hipertensão arterial, busca na rua sua própria alimentação. Nas visitas domiciliares realizadas, sempre o encontrei executando alguma tarefa doméstica, sujeitando-se às ordens dos demais familiares. Nesse sentido, Rosa e Osmar parecem não habitar suas casas, não se apropriam do espaço (propriedade material e afetiva), configurado pelo anonimato e pela falta de marcas do sujeito e onde não há poder de decisão, nem material, nem simbólico do indivíduo (Saraceno, 1999). No mais alto grau, habitar significa não sujeitar-se a nada e a ninguém, exercer sua autonomia; nesse sentido, os escravos e servos não habitam, pois não dispõem de si mesmos (Kujawski, 1991).

Os temas moradia e alimentação foram tratados por alguns entrevistados de maneira mística, sendo “Deus” o responsável pela sobrevivência e pela aquisição de uma moradia melhor. Explicações místicas e sobrenaturais, relacionadas aos mínimos sociais (“mas graças a Deus eu não fico sem comer não” - Antonia ou “agradecer a Deus por a gente ainda estar em cima naquele canto” - Adriano), parecem mais razoáveis que explicações objetivas e críticas sobre a falta de acesso à bens e serviços (Lima, 1983). Para os sujeitos entrevistados, que conduzem suas vidas a partir da categoria principal da provisão (Valla, 1998), a fé estaria relacionada às soluções imediatas das demandas do dia a dia. Segundo o autor, a fé poderia ser compreendida como uma importante estratégia de resistência à pobreza, 
redimensiona a vida do sujeito e lhe dá forças para lutar por melhores condições de vida. A religiosidade, ao oferecer um "senso de coerência”, dá sentido à vida do sujeito (Valla et al., 2005). Para Adriano, ainda num tom de misticismo, o Estado, na figura da prefeita, fez justiça, contemplando aqueles que sofreram e persistiram diante de situações adversas de sobrevivência e moradia. Para ele, diante de tanto sofrimento, não há outra alternativa se não rezar e pedir a Deus um futuro melhor.

Segundo Lima (1983), a luta pela sobrevivência é tão intensa em alguns casos que o processo de alienação se torna maior. Porém, segundo a autora, as compreensões místicas da realidade também podem ser uma recusa à sujeição e à violência imposta pela vida cotidiana, podendo ser um germe de questionamento e mudança da situação em que vivem. Os entrevistados deste estudo, contudo, pouco expressaram críticas ou questionamentos quanto à situação social e econômica em que vivem e relacionam sua condição de vida à presença ou ausência de oportunidades e méritos individuais que possuem. No caso de Antonia, após a aquisição da deficiência, sua vida se tornou ainda mais precária e “aí e eu não consegui mais nada na vida”.

Pagar a comida e o aluguel são as prioridades para sobrevivência dos entrevistados, que vivem condições semelhantes a dos demais moradores de bairros periféricos da cidade. Porém, as condições de vida, o acesso a bens materiais e serviços são mais restritos, dada a situação da presença da deficiência e a dificuldade na realização de atividades de geração de renda, considerando também que, nos casos apresentados, a dependência das pessoas com deficiência pode gerar a situação do impedimento do cuidador em realizar alguma atividade profissional. O trabalho, 
uma das esferas mais importantes da vida cotidiana, será discutido a seguir, a partir das experiências dos sujeitos entrevistados.

\subsection{Trabalhar: uma forma de reconhecimento social}

Sobre o trabalho, Osmar, relatou:

Tem uma parede da dona Maria aí, ó, o cara vai me chamar aí ó, vai dar pra pegar um dinheiro aí, vou lixar lá pra ela lá...

(...) tem tudo isso, tem a casa de Penha pra lixar, tem o portão... tem tanta gente que me chama pra lixar uma casa, uma parede, uns negócio...

(...) tem uns serviços pra mim, tem essa não, trabalho, levo as coisas pros outros aí, ganho o meu dinheiro... Uma vez eu fui levar os azulejos pro cara, e ele me pagou tudo em dinheiro assim pra mim. Me pagou todo o dinheiro pra mim.

(...) e aí, o que você fez com a grana, você lembra? (entrevistadora)

Eu lembro. Não gastei.

[riso] que eu fiz? Explica.

(...) [pausa] Não gastei. ...Dei tudo. ...Pra minha mãe, tudo. Fiquei sem nada no bolso. Não quero ficar com mais nada no bolso não. Eu não compro doce, não faço nada (Osmar, 21).

Rosa relatou sobre sua primeira experiência de trabalho, aos 24 anos, quando foi contratada como auxiliar de limpeza no Hospital das Clínicas de São Paulo. Após crises (epiléticas) foi readaptada para o cargo de recepcionista na creche da instituição.

(...) Da creche, só saí agora, depois de aposentada.

Era gostoso, né... Inclusive as crianças que passou por mim, quando era bebezinho, tornaram outras criança! O que eu vejo são duas meninas aqui que são de lá... que passavam por mim que tão maiores do que eu!

Porque, era uma coisa que eu tava gostando. Fazia bem pra mim, sair de casa, ir pro serviço, voltar. Fazer as coisas dentro de casa... Tava fazendo bem pra mim. Agora eu tô inútil! (novamente bate as mãos contra as pernas).

A mãe de Rosa, Iraci, também se recordou do período em que a filha trabalhava, organizava a casa e cuidava do bebê, rotina que foi interrompida pelas crises epiléticas: 
Porque tá certo que esse negócio dela ficar muito parada, porque ela sempre foi ativa né, ela levava a menina, ia pro serviço, trabalhava lá, chegava, ainda ia lavar roupa na mão porque não tinha nem máquina, né, passava as roupa dela, que a roupa dela sempre foi bem passadinha, a cama ela sempre forrou, que era muito pesada... tudo isso ela fazia direitinho (Iraci, 72 anos).

Para os entrevistados, com exceção de Marisa, que nunca realizou atividade remunerada, o trabalho foi uma das esferas do cotidiano de maior relevância. Em nossa sociedade, a inserção no trabalho é a expectativa de todo jovem e adulto, sinônimo de independência financeira, autonomia, autorealização, maturidade, reconhecimento social e poder. O processo de aquisição da deficiência, condição enfrentada por três sujeitos entrevistados, teve como consequência importante o afastamento do trabalho, o que gerou sofrimento e acentuação do sentimento de desvalorização social. No caso de Antonia, Rosa e Adriano o processo de ruptura com o trabalho foi efetivo e a reapropriação da vida cotidiana ocorreu de modo singular para cada entrevistado de acordo com as habilidades remanescentes, a aquisição de benefícios previdenciários e apoio familiar e social, com o qual cada sujeito pôde contar para reestruturar o cotidiano. Para Osmar, jovem com deficiência mental, o trabalho também tem importância central em sua vida, porém é uma atividade que exerce a partir de contradições e conflitos, dadas as condições sociais e cognitivas que possui além do contexto onde desenvolve as atividades.

Para Osmar, trabalhar é essencialmente ganhar dinheiro, embora não usufrua deste recurso e ofereça todo dinheiro à mãe. Na fala de Osmar observou-se que é através do trabalho que ele se relaciona e é reconhecido socialmente. D. Maria, D. Penha, o “cara dos azulejos” são figuras importantes na vida dele, que solicitam seu trabalho e em troca o remuneram, lhe dão comida e atenção. Porém, moradores e familiares afirmam que Osmar é ingênuo, não reconhece o valor do dinheiro e, por 
vezes, é explorado por alguns de seus contratantes, sendo sub-remunerado. Nesse sentido, a comunidade é ambígua: ela é provedora de oportunidades, mas também se caracteriza como um espaço de exploração, reproduzindo as relações sociais de dominação e humilhação em detrimento das relações pautadas na solidariedade e na ética.

Para Antonia, que teve a vida produtiva interrompida pela aquisição da deficiência, o trabalho é lembrado de modo saudoso, embora a descrição das atividades realizadas indique um cotidiano penoso no que se refere ao desgaste físico e emocional ao cuidar de pessoas idosas e dependentes. Antonia, ao relatar esse momento de sua vida, empregou os verbos no presente (às vezes eu tô na lavanderia, às vezes eu tô na limpeza...), como se ainda estivesse trabalhando neste local. Embora nos dias atuais exerça funções como a de cuidadora de senhora idosa e de faxineira, referiu que, após o emprego no asilo, nunca mais trabalhou. Talvez para Antonia a realização de atividades no mercado informal não tenha status de trabalho, sendo as atividades domésticas realizadas pela mulher pouco valorizadas socialmente.

No caso de Rosa, a reestruturação da vida cotidiana após o afastamento do trabalho mostrou-se inconsistente, dada a condição de sofrimento psíquico e do isolamento social. A função que exercia na creche, de controlar a entrada e não permitir que nenhum homem (pai) retirasse as crianças, pareceu uma função de controle, que correspondeu às suas competências e ao perfil pessoal. Porém a crise epilética, que segundo ela provocou medo em suas colegas, bem como a fragilidade psíquica, a afastaram do trabalho. Recebeu a notícia do mau prognóstico pelo médico e permaneceu "tocada", escondida em uma toca, onde parece permanecer até os dias 
atuais. Rosa sente falta das ações do cotidiano que realizava no período em que trabalhava: levantar, arrumar o bebê, sair, ir para o serviço, voltar, fazer as coisas dentro de casa. Diante desta ruptura sente-se inútil, incapaz de retomar as atividades mais elementares para sua própria sobrevivência.

Os entrevistados apresentaram as contradições presentes no campo do trabalho e da pessoa com deficiência em suas diferentes dimensões e possibilidades. As experiências de trabalho apresentadas dizem respeito a uma conjuntura econômica, social e política na qual o corpo humano tem sido compreendido como uma máquina de produção, totalmente alienado ao trabalho e sequestrado de seu aspecto subjetivo, sendo alvo de sofrimento psíquico e físico, de humilhação social e opressão. Essas são as vivências de trabalho impostas à maioria dos trabalhadores moradores de áreas periféricas da cidade de São Paulo, e que podem estar relacionadas aos processos de adoecimento e de aquisição de deficiências relatadas pelos entrevistados. Embora o trabalho tenha sido abordado a partir da demanda de participação comunitária e de sobrevivência, as experiências também o indicam como fonte de sofrimento e alienação, uma característica importante da vida cotidiana.

Contudo, o sonho de um futuro melhor ainda está relacionado à esfera do trabalho. Para Marlene, ao pensar no futuro de Osmar, ela evoca a lógica da ordenação social e do mérito individual: por se tratar de um menino bom, trabalhador, “eu tenho certeza que mudar pra pior ele não vai”. Ser trabalhador é a qualidade que o afastaria do risco social da delinquência e da violência. Ela reconhece que, no futuro, possam existir políticas de trabalho para pessoas com 
deficiência, o que para O. seria uma oportunidade de trabalho e, consequentemente, patamar para a cidadania:

(...) porque eu sei que ele não pode trabalhar (Osmar), mas, diante das alternativas que aparecer, e o governo constatar que doente mental pode trabalhar, quero que trabalhe também, porque nada vem, passa se não tiver do suor do seu rosto. Você concorda? É o que eu quero pro Osmar, que, graças a Deus eu não tenho o que dizer, não é um moleque que fica pra lá e pra cá, não é um moleque que fica com mau andamento pra lá e pra cá, as amizades dele pode ser erradas, mas não se mistura, né, todas as pessoas que dão coisas pra ele são pessoas boas, então eu acho que quem se mistura com uma safra de uva boa, vai dar colheita boa (Marlene, 45).

\subsection{Conversar: o desejo de romper com o isolamento social}

A conversa será, talvez, a ocupação mais deleitosa e fecunda do cotidiano. Deleitosa, porquanto permita o reconhecimento sem reserva das pessoas entre si; fecunda, porque, ao contrário de "perder tempo", como pode parecer, é ganho de tempo à medida que perfazemos nossa experiência própria com a experiência do outro (Kujawski, 1991 p.47).

Conversar, bater papo, encontrar-se com amigos, parentes, vizinhos, e trocar experiências, conhecer outras perspectivas e realidades de vida. Ao conversarmos, nos tornamos mais criativos e livres. As pessoas com deficiência entrevistadas, em sua maioria, afirmaram e demonstraram que gostam de conversar (por exemplo, através do interesse em participar da entrevista, entendendo-a como um momento de conversar, de aparecer para o outro). Porém relatam que esses momentos são raros em suas vidas, pois as oportunidades de convivência social são restritas, com predomínio da situação de isolamento domiciliar. Assim, neste momento, será discutida a categoria isolamento, por considerá-la a antítese da conversa. Esta opção se deu através da percepção da condição de isolamento como principal questão abordada pelos entrevistados e geradora de certo grau de sofrimento. É claro que a conversa está presente na vida das pessoas com deficiência, sendo um elemento 
estruturador e mantenedor de suas vidas. Assim, elencamos alguns trechos das entrevistas que relatam situações e críticas quanto à situação de isolamento dos entrevistados:

Não, não ando com ele.

Com quem você anda? (entrevistadora)

Eu ando sozinho.

Você não tem amigos aqui no MOVA

Não, eu ando sozinho.

Você não tem amigo, Osmar?

Nenhum.

Eu ando sozinho (Osmar, 21).

Ele conversa, ele cumprimenta, mas não é de estar andando alinhado com ninguém, não. Entendeu? É ele e só e só e só mesmo (Marlene descreve o filho Osmar).

Ah, divertimento, ai... agora... é, se tivesse pelo menos um (carro), pra me locomover, pra sair daqui, dava muito bem, mas acho muito difícil, bem que eu gostaria, de sair, passear, ir nos lugares, ir pra casa dos parente, da turma, dos vizinhos, da família, mas... não posso, é... desse jeito mesmo, aqui, ... quem puder, se ajudasse, mas acho muito difícil... mesmo eu queria mesmo sair, passear, ir pros lugares, ir pros lugares legais... mas... (Adriano, 29).

No início da entrevista, Marisa disse que acalmou o "seu nervoso” com as saídas e os passeios promovidos pelos profissionais da Unidade Básica de Saúde (UBS) e pelo Conselho Municipal da Pessoa com Deficiência (CMPD). Antes permanecia somente em casa:

Eu tava muito nervosa. Me acalmei.(...).Aliviar?(...).Aí minha irmã falou assim: vai passear hein? Sr. Zé... ficar alegre! (pessoa com deficiência que a acompanha nas atividades do CMPD)

Então os passeios, as saídas, foi uma coisa boa que aconteceu na tua vida (entrevistadora)?

É Foi bom pra mim.

E antes como era?

Antes? ...........o portão pra dentro.

É. Não saia mais de casa. Aí chorava, chorava,

Aí vamos ver com a Marta, aí foi indo, foi indo, aí me acalmei, me acalmei, Marta. Me acalmei.

A Stella vem me buscar, eu vou pra lá me acalmei Marta (Marta é a entrevistadora e Stella, terapeuta ocupacional da UBS)

Marisa falou sobre a solidão quando permanece sozinha em casa. 
E quando você fica sozinha, o que você sente?(entrevistadora)

Aí eu fico assim, sentindo falta de alguém, sente muita falta.

Eu acostumei de conversar. Me dá solidão......eu fico lá assistindo à novela (Marisa, 46 anos).

Rosa, vivencia a condição de maior grau de isolamento domiciliar entre os pesquisados. Durante a entrevista ela refletiu sobre essa condição: “Quando eu falo: me leva? “você não pode!”(responderiam os irmãos). Rosa buscou explicações para esta negativa: “Olha, eu não sei... Talvez porque eu não ande normalmente como andava, porque depois que eu operei o pé, pronto! Ou porque fuma compulsivamente.

Já no final da entrevista, quando pergunto sobre a sua experiência em frequentar o grupo de convivência Vida Nova, Rosa relata:

Bom, eu... Ai... (não consegue falar e pede desculpa, parece cansada) Desculpa, Desculpa, Desculpa... (pausa) ...eu não fui tanto lá pra ver bijuteria (atividade realizada no grupo), eu fui pra escapar de dentro de casa. Que eu tô cansada de ficar presa. E essa prisão aqui tá me matando! ...ninguém tá vendo, mas tá me matando. ...Quem pensa que é o cigarro que me mata, não é! É a prisão da casa! Ninguém quer que eu olhe pros lados, ninguém quer que eu escute! Ninguém quer que eu fale! Ninguém quer que eu olhe! Poxa vida! Eu não nasci surda, eu não nasci cega, eu não nasci muda! Porque tão impedindo (pausa) ...Agora, só porque as minhas perna tão um pouco imobilizada, ninguém quer ter um pouco de sacrifício pra me colocar lá fora, me ajudar! (...) (Rosa, 45).

Os entrevistados abordaram a condição de isolamento social, e, assim, pensamos em algumas questões objetivas e subjetivas que podem auxiliar na compreensão destas situações: a intolerância à diferença, a valorização do individual em detrimento do coletivo, as diferentes formas de estruturação familiar contemporâneas, a falta de acessibilidade e transporte adequado para pessoas com deficiência, a fragilidade das relações de solidariedade e a própria condição de confinamento que produzem sujeitos fragilizados e com muita dificuldade para estarem no convívio social. 
Frequentemente vemos Osmar caminhar sozinho pelas ruas do bairro, o que confirma seu depoimento de “sempre andar sozinho” e “não possuir amigos”. Como disse a mãe, Marlene: “a Cohab inteirinha conhece ele! Você pode perguntar pra qualquer um, e desde do mais direito até um nóia, quem é o Osmar”. Nesse sentido Osmar vive uma contradição: “o pessoal aqui adora ele” (sic-mãe), porém está sempre sozinho. Este é o lugar social reservado para alguns deficientes intelectuais na comunidade, marcado pela proteção (ou pela exploração de sua força de trabalho), pela infantilização e pela percepção equivocada de que estes sujeitos não são capazes de realizar trocas sociais e afetivas. Nesse sentido, Osmar e Marisa, sujeitos que apresentam a deficiência intelectual, vivenciam mais intensamente a situação de intolerância à diferença e ocupam um lugar marcado pela desvalorização social. No caso de Marisa, mulher com deficiência intelectual, a situação de isolamento no domicílio é mais intensa. Para Osmar, que circula pelo bairro (e somente neste espaço geográfico) a percepção da hostilidade e do risco em estabelecer alguns contatos sociais o faz adotar uma postura mais isolada, se aproximando apenas daqueles que demonstram algum grau de afetividade e carinho. Já Rosa, ao refletir sobre as razões de seu isolamento, focou-se em suas próprias incapacidades e características (caminhar com dificuldades e fumar), com certa crítica à sua condição pessoal, porém pouco questionou as condições sociais e ambientais que poderiam auxiliá-la no enfrentamento desses impedimentos, que a distanciam dos familiares. Para ela, o isolamento é uma questão crucial em sua vida: “quem pensa que é o cigarro que me mata, não é! É a prisão da casa”. Assim Rosa denunciou a solidão como o principal aspecto da vida cotidiana que a faz sofrer. 
Aliada à intolerância à diferença, está a construção de uma sociedade cada vez mais preocupada com os espaços e as questões privadas, esquecendo-se do coletivo e do ser genérico. Neste processo coloca-se em risco uma das estratégias de sobrevivência mais importantes das comunidades pobres, que é a solidariedade e a complementaridade. A sociedade capitalista, pautada no consumo e na produção de bens, produz sujeitos oprimidos e focados na sobrevivência cotidiana. A presença de uma pessoa com deficiência é questão para ser tratada pela família, às vezes por um só cuidador; não é assunto para ser abordado pela comunidade, pelos vizinhos, pela igreja e equipamentos sociais. No limite da situação de isolamento, às vezes, nem o Estado é convocado para garantir condições mínimas de sobrevivência para o sujeito.

Somadas a estas questões, consideramos também as dificuldades objetivas que perpetuam a condição de confinamento das pessoas com deficiência em seus domicílios. Pode-se citar a existência de espaços inacessíveis com a presença de barreiras arquitetônicas (calçadas e pisos irregulares, presença de escadas, ausência de elevadores, entre outras situações) e a falta de uma rede de transporte adaptado para pessoas com mobilidade reduzida, constituída ainda de forma precária e pela inexistência de uma malha viária que garanta a circulação da pessoa com deficiência em todas as regiões da cidade. Pouco adianta existirem escolas, cinemas, teatros, shoppings centers, parques adaptados, se as pessoas com deficiência não possuem transporte adequado para acessar esses locais. Nos relatos de Adriano e Marisa, a demanda por romper o isolamento é clara; eles querem passear, conversar, namorar, estudar, enfim, realizar as atividades inerentes à vida humana. O lazer, as saídas de casa, os raros momentos de rompimento do isolamento sustentam e tornam a vida cotidiana mais interessante para se viver. 


\subsection{Passear: a possibilidade de conhecer os recursos da cidade}

Passear, segundo Kujawski (1991), é uma forma de estar efetivamente na cidade, apropriar-se dela a partir das condições e das possibilidades do sujeito. Ao passear, observamos cena por cena, o aqui e o acolá; os espaços passam a ter um valor e um significado singular e assim ganhamos nossa identidade, a partir do contorno que a cidade nos dá:

No hábito de sair pelas ruas exclusivamente para ver e passear, balizamos nosso cotidiano de uma trama de referências e significados interpessoais, constituindo um circuito intraurbano fechado, que nos permite a grata satisfação do reconhecimento: reconhecer o contorno e ser reconhecido por ele: assim, ganhamos o papel e o argumento que nos estão reservados a nível do cotidiano (Kujawski, 1991, p. 50).

A contemplação da cidade e de seus recursos são momentos raros na vida das pessoas com deficiência entrevistadas. Isoladas em suas casas ou em seus bairros, anseiam pela descoberta dos espaços externos em busca de contornos, que ofereçam mais elementos para humanizar suas vidas. Esses sujeitos mostraram-se apartados de mais uma das esferas da vida cotidiana: o lazer é escasso e o tempo é vivido, em grande parte, através do ócio e da quase impossibilidade de realizar escolhas livres no campo da diversão, do entretenimento e da criação, que proporcionem satisfação e transformação no campo pessoal e social.

O lazer, termo amplamente utilizado pela sociedade, está relacionado com as vivências objetivas e concretas de cada sujeito ou grupo, que possibilita um significado imediato ao termo. Portanto, a compreensão do lazer está relacionada com experiências concretas, necessidades e desejos dos sujeitos, existindo diferenças 
sociais, econômicas, de idade e gênero, o que confere ao lazer atribuições, definições e valores diversos (Marcelinno, 1983).

Segundo o autor, o lazer pode ser analisado a partir de seus riscos e possibilidades: pode promover a mudança e/ou mesmo a manutenção da ordem social; pode ser um fenômeno revolucionário, promover transformações no âmbito das atitudes e valores, mas também pode servir à imposição da cultura ocidental massificada, com tendências à manutenção do sistema de produção e consumo. O lazer passou a ser compreendido como hora de descanso, de não trabalho, momento de reparação do corpo produtivo, instalando-se o binômio trabalho/lazer. O lazer também pode ser desqualificado, quando associado à ideia do ócio e do não fazer. Essa compreensão está relacionada à supremacia do trabalho enquanto forma privilegiada de realização pessoal e desqualifica o lazer, algo realizado nas horas vagas, sem grande importância. Aqui se esquece do lazer como parte orgânica do cotidiano.

Ao considerar o binômio trabalho/lazer, as pessoas com deficiência, quando afastadas das possibilidades produtivas nos moldes capitalistas (que priorizam o corpo produtivo, o intelecto e a qualificação), estão ainda mais apartadas das possibilidades de lazer, enquanto categoria do cotidiano, lhes restando o ócio (entendido aqui em contraponto ao lazer, que considera sempre a realização de alguma atividade) e formas particulares de lidar com o tempo disponível (Marcellino, 1983), que propiciem sensações de satisfação e bem-estar.

Ao ser questionado sobre as atividades que gostava de realizar, Osmar respondeu prontamente que gostava de trabalhar. Quando solicitado a pensar em outras atividades, ele disse: 
Ah, sair...

Sair pra onde? (entrevistadora)

[riso] Pra onde?

(...) Ah, eu ando por aqui e por lá...

Para Adriano, que possui a vocação do desenho e da pintura, o campo das artes tem lhe promovido bem-estar, satisfação e prazer. Adriano relatou que é na rua e nos passeios onde tem encontrado inspiração e modelos para desenhar. Combinação entre a arte e a rua:

Só desenhava, desenhava uns desenhos legais, primeiramente comecei a desenhar castelo, (...), primeiramente comecei a fazer uns caminhões, fazer carrinho, (...), comecei a fazer castelo. (...)Aí teve um dia que eu tinha uma camiseta tinha um desenho do Coringa, (...)

Da camiseta, pra cartolina, aí fui tirando, (...) até que eu fiz perfeitinho, fiz perfeito [riso],(...) e aí eu saía, quando eu ia pra passear,(...)e olhava pro rosto das pessoas assim, o formato do rosto, aí comecei a fazer o formato do rosto daquela pessoa,(...)

Quando estive lá no (...) parque do Carandiru, que tinha uma menina que tinha o rosto tudo pintadinho assim, desse mesmo jeito assim (Adriano mostrou à pesquisadora o desenho).

Os passeios, organizados pelas terapeutas ocupacionais na Unidade Básica de

Saúde são lembrados com entusiasmo pelos entrevistados:

Agora, eu passeio só com você... Ainda a outra (uma amiga da comunidade) ficou brava comigo porque, por que você não chamou?

(...) eu peguei pra ela e falei assim: foi de repente, fia, que eles me deram a passagem pra ir... não tinha quase ...nossa você foi no passeio!(teria dito a amiga)...e comi muito!!!!!.

[Risos]

Ainda tirei sarro dela...

(...) O que você achou do passeio? (entrevistadora)

Gostei, fia, adorei.

(...) É, foi tudo muito lindo... que tiraram fotografia também... muito lindo, fia... Aí eu falei que os passeios que eu gostei é todos negócios que você vai eu gostei...

Se é bom ou ruim eu não sei, mas foi tudo maravilhoso. Aí o rapaz achou que eu ia subir (no Pico do Jaraguá), aí falei não, que eu não aguento subir.

(...) E você, na sua vida você já passeou? O nde você passeou?

Eu já passei muito... dancei muito...

(...)Forró. (Antonia, 54)

Adriano, assim como Marisa, passou a participar das reuniões do Conselho

Municipal da Pessoa com Deficiência, uma experiência política no campo das 
discussões sobre os direitos das pessoas com deficiência. Ele falou sobre suas percepções acerca desta experiência:

Do conselho, da plenária, né... tenho! Tenho, saio daqui, vai pra lá, escuta palestras...

(...)

O que tem de mais interessante mesmo é que você sai de dentro de casa. Sai de dentro de casa, sai, conhece outros lugares, vai pro centro da cidade, faz tanto tempo que não fui pro centro da cidade (...)

(...)Agora o conselho, eu fico, ah, fico prestando atenção lá, fico lá, escutando as palestra, (...) ah, eles falam do ônibus, falam de, de... cada ponto tem um, (...)coordenador de, eu não sei como explicar, é muito difícil de falar, mas lá a gente escuta coisa de ônibus, de ônibus, perua, (...)como chama, representativo também , tudo isso que fala: saúde, de doença, tudo fala. Cada ponto tem, (...) aparece um estagiário lá, esse negócio de doença, de AIDS, camisinha, sempre toca nesse assunto, deficiente, deficiente que não entra, fala de sexo, também, (...) (Adriano, 29).

Para Rosa, romper com o isolamento é ir ao médico:

Não aguento mais.

(...) a vida de ir pro médico.

[pausa]

É médico pra tudo quanto é lado. Mês que vem eu tenho médico.

Você lembra-se da ultima vez que saiu de casa? (entrevistadora)

Só quando eu vou ao médico.

Infelizmente. Agora ele olha pra mim, assina, e tchau! [pausa] não faz exame de pressão, não faz exame de não sei o que, nada.

Osmar gosta de sair, andar, por aqui e lá. Possui a liberdade de caminhar pelas ruas do bairro, coletando alimentos e objetos. A exploração dos espaços do bairro está relacionada à busca por trabalho: um muro para pintar, um terreno para carpir, areia para tirar da calçada e levá-la para o quintal. Passear pela cidade é um fato raro em sua vida, assim como na de muitos moradores do bairro. A falta de recursos financeiros, dificuldades em acessar o transporte coletivo (principalmente nos finais de semana) e a falta de informação quanto às atividades de lazer e cultura oferecidas na cidade acentuam a situação de isolamento das pessoas nos bairros periféricos. O lazer, discutido a partir da vertente da cultura da pobreza e da teoria das necessidades prioritárias, é considerado apenas para as camadas sociais mais 
abastadas, que puderam suprir as necessidades básicas como saúde, alimentação e habitação. Para a população pobre, o cotidiano está centrado na manutenção da sobrevivência, e o lazer é considerado atividade secundária (Marcelinno, 1983).

Antonia falou com desânimo sobre o tema. Embora participe de algumas atividades comunitárias, pois gosta de distrair e conversar com as amigas, dar risadas, tudo isto parece pouco e ela diz que não tem mais aquela vontade. Tem hora que dá uma agonia que você quer voar. Tal relato parece revelar a opressão à qual esta mulher foi submetida ao longo da vida, o que lhe subtraiu o desejo e a vontade em investir em seu projeto de vida. Porém, lembra-se que já dançou e divertiu-se muito, atividades que foram abaladas com a instalação da deficiência. Hoje, as alternativas oferecidas pela comunidade são pouco atrativas e já não despertam o interesse de Antonia. Fazer ginástica e participar do grupo da terceira idade parecem atividades que pouco correspondem aos seus desejos e necessidades e indicam um fazer pouco criativo.

Porém, quando os sujeitos falaram sobre oportunidades de lazer, lembraramse dos passeios comunitários como momentos de prazer, satisfação, aprendizado e intensificação das relações sociais. Antonia contou com alegria, que, ao contrário da amiga, teve a oportunidade de passear pois "de repente, eles me deram a passagem”, como situação de sorte e privilégio. Lembra-se que comeu bastante, novamente indicando a importância da alimentação quando se vive a escassez de comida. Para Adriano e Antonia, passear foi uma forma efetiva de estar na cidade, apropriar-se biograficamente dela (Kujawski, 1991). Adriano teve oportunidade de visitar novamente o zoológico, conhecer o Parque do Ibirapuera e, nesta ocasião, estreitar os laços afetivos com uma amiga, Patrícia. Porém, diante de experiência tão 
inédita, ficou nervoso e passou mal na frente de todo mundo, como qualquer outro homem ficaria diante de uma pessoa afetivamente especial.

Nas reuniões mensais do Conselho Municipal da Pessoa com Deficiência das quais participa, torna-se evidente que, além de romper com o isolamento social, Adriano aprendeu sobre temas diversos e embora "não saiba explicar", elencou os temas mais importantes relacionados à sua própria existência e aos problemas que tem enfrentado em seu cotidiano: lá discutem sobre saúde, transporte e sexualidade. No grupo, Adriano percebeu que suas demandas são compartilhadas por um coletivo, pessoas que apoiadas por "representantivos” e “estagiários”, acessam informações e reivindicam direitos sociais. Talvez seja esta a oportunidade de Adriano e de seus demais colegas do conselho suspenderem a particularidade do cotidiano e abordarem o aspecto genérico humano, através da consciência crítica como forma de transformação social:

A vida cotidiana, portanto, se insere na história, se modifica e modifica as relações sociais. Mas a direção destas modificações depende estritamente da consciência que os homens portam de sua "essência" e dos valores presentes ou não ao seu desenvolvimento (Carvalho; Paulo Netto, 2007, p.29).

O lazer, como esfera do cotidiano também está intermediado pelas formas de comunicação em massa, principalmente pela televisão e pelo rádio, como importantes disseminadores de valores e costumes. Na pesquisa apresentada por Lima (1983), o cotidiano da população pobre entrevistada é preenchido, sistematicamente, por programa de rádio e televisão. Para as pessoas com deficiência entrevistadas, o tempo livre ou o tempo disponível (Marcelinno, 1983) também é preenchido através do uso da televisão, porém todos afirmaram que esta atividade 
ocorre de modo pouco sistemático e, muitas vezes, é geradora de sentimentos como impaciência e falta de interesse.

Para Rosa, que acessa os espaços externos ao bairro somente para ir ao médico, a televisão e o rádio mediam sua relação com o mundo social, situação vivenciada de modo fantasioso, que parece anestesiá-la para a vivência de um cotidiano sem sentidos e marcado pela solidão:

Não, só tem uma programação que eu assisto, os outros eu não pego mais não. Eu já até tenho horário, então eu nem ligo a televisão. A Malhação (programa de televisão destinado aos adolescentes)

...eu gosto de olhar as aventura das crianças, eu gosto só disso. Pra passar meu tempo. Também aí, terminou, eu viro, eu ligo rádio e aí eu ouço música até às oito horas, depois desligo, aí eu vou dormir(Rosa, 45).

Quanto às demandas de lazer, enquanto Antonia mostrou-se muito “desanimada” para explorar o tema, centrando-se mais na falta de perspectivas em investir neste tipo de atividade e referindo-se aos golpes que sofrera na vida, Adriano, ressaltou positivamente as oportunidades de lazer e os compromissos sociais dos quais participou, mostrou-se motivado a projetar e demandar mais oportunidades: desejou conhecer novos lugares, não se contentando mais em conhecê-los através da televisão.

Agora... pra onde você (...) gostaria de ir que você nunca foi? (entrevistadora) Eu nunca fui pra lugar nenhum, fia, não quero não, fia... Pra Bahia também se eu for é pra visitar a minha filha, só, não quero morar lá.

(...) eu sou desanimada!

(...) eu sou muito desanimada na minha vida... (Antonia, 54)

\section{Já Adriano:}

E tem algum lugar que você gostaria de conhecer que você não foi ainda? (entrevistadora) Tem, tem, mas os carros não chega lá.

(...) os carro não chega. O que eu queria mesmo era ir pro lado de Cotia, que tem muitos lugares bonito, que eu já fui, que eu já vi, muitos lugares bonitos. Aqui pro lado de Cotia tem um pouso de, (...) como é chama? 
(...) objetos não identificados,

(...) É, pesqueiro, pescar, eu tô pensando em comprar um jogo de vara, um vizinho aqui meu vai, todo fim de semana que ele tiver dinheiro ele vai, que é o Gaspar, que me ajuda. (...). Então eu gostaria de pescar, eu falo que eu gostaria de pescar, pra ele aí, quando eu encontro, e aí? Que dia você vai pescar, e ele fica, ah, hoje não vai dar não porque os peixes estão tudo escondido, que nem coelho...(Adriano, 29).

E faz um pedido à terapeuta, afirmando que é muito bom passear:

(...)Mas deixa ir mais pra frente, quando eu comprar minhas coisas, aí eu vou ver se eu, fala assim: ô Marta, já comprei minha vara de pescar, agora tá na hora de você marcar uma hora pra nós ir! Aí já convence, né?

Para os entrevistados, passear foi a categoria que mais suscitou demandas e possibilidades de romper com o cotidiano marcado pelo isolamento social, pelo ócio e por ações de sobrevivência. Porém, na heterogeneidade da vida cotidiana (considerando as categorias habitar, comer, trabalhar, conversar e passear) a hierarquia também tem sido determinada pelas condições sociais e econômicas sendo o habitar e o comer necessidades a serem respondidas na urgência do dia a dia. A simplicidade e a precariedade das moradias e da alimentação, bem como a experiência da fome e da falta de propriedade (afetiva e material) da casa, foram assuntos abordados pelos entrevistados também pelo viés da religiosidade e da fé, que apóiam os sujeitos no desejo de um futuro melhor. Trabalhar mostrou-se como a categoria organizadora da vida de alguns sujeitos entrevistados, mesmo quando realizada de modo precário e penoso (como é o caso de Osmar e Antonia). Para os entrevistados que tiveram a vida produtiva interrompida pela aquisição da deficiência, parar de trabalhar significou sofrimento, acentuação do isolamento e o sentimento de desvalorização social. Em alguns casos, o trabalho da pessoa com deficiência pôde ser considerado uma expectativa de desenvolvimento e 
possibilidade de exercer cidadania. A categoria conversar mostrou-se como uma demanda muito importante na vida dos entrevistados, porém o que prevalece é a situação de isolamento social, seja pela existência de barreiras atitudinais com relação à pessoa com deficiência, seja pela presença de barreiras físicas que dificultam a circulação do sujeito no bairro e na cidade; tal isolamento também pode ser determinado pelas condições sociais e pela falta de recursos financeiros presentes nas famílias entrevistadas. Considerou-se ainda a importância da presença do Estado na vida cotidiana dos sujeitos que possuem deficiências graves (na forma de benefícios assistenciais monetários e políticas públicas nas diversas áreas sociais) e as dificuldades e contradições presentes no acesso a estes recursos. Numa sociedade pautada pela produção e pelo consumo e que produz inúmeras contradições sociais, o Estado deve garantir a proteção de sujeitos impossibilitados ao trabalho, como é o caso das pessoas com deficiência entrevistadas.

Conhecer e refletir sobre o modo como a vida cotidiana destes sujeitos está organizada é um caminho possível e interessante para reorientar a assistência destinada à esta população. 
6 GRUPO DE CONVIVÊNCIA VIDA NOVA: UMA POSSIBILIDADE DE LIDAR COM AS DEMANDAS 
Neste estudo, observamos que a procura por intervenção (portanto demanda) esteve quase sempre relacionada às carências no âmbito da saúde. Para Pinheiro et al. (2005), a definição de demanda em saúde pode estar pautada na lógica econômica ou biomédica. O que elas têm em comum é a redução do sujeito na doença. Assim, o tratamento da doença seria sinônimo de "reais necessidades de saúde da população" e o motivo que conduziria as pessoas à procura por assistência.

Adriano, durante a infância, procurou auxílio médico, pois não aprendia a ler e escrever; quando jovem peregrinou por serviços de saúde e reabilitação em busca de um diagnóstico médico, só esclarecido quando tinha 27 anos de idade. Marisa realizou tratamento em reabilitação quando criança (ela recordou-se que fazia exercícios com a mão). Antonia, frequentemente, procura a unidade básica de saúde, pois seus pés estão sempre inchados e a hipertensão arterial descompensada. Marlene, mãe de Osmar, relatou que após indicação de profissional da rede de ensino regular, procurou assistência em escola especial, porém não conseguiu atendimento; apenas aos 19 anos, o jovem foi assistido em serviço de saúde para adolescentes, sendo diagnosticado como deficiente mental. Rosa tem seu itinerário restrito às consultas médicas; nunca realizou tratamento em reabilitação ou outra especialidade não médica.

As experiências relatadas pelos entrevistados nos fizeram refletir sobre as respostas oferecidas pelos serviços de saúde e reabilitação, às demandas dos sujeitos. Respostas tardias, incompletas, muitas vezes focadas no atendimento médico clínico, que apaziguaram parcialmente as carências das pessoas com deficiências e de suas famílias. De acordo com a organização dos serviços de saúde, estas são as respostas 
possíveis de serem geradas, o que, segundo Schraiber e Mendes Gonçalves (1996), estabelece um contexto instaurador de necessidades.

Porém, em muitos momentos, no início da constituição do grupo, nos deparamos com o impasse da falta de demanda. Pessoas com deficiência e/ou familiares que, em princípio, nada nos demandam. Para Costa e Brandão (in Fleury, 2005), que refletem sobre a clínica comunitária, a falta de demanda não significa falta de pedido de ajuda. Para as autoras, oferecer a disponibilidade da escuta e do diálogo são formas de precipitar o surgimento de pedidos de ajuda. Somos “provocadores de demandas”. Acreditamos que a falta delas está relacionada à ausência de oportunidades e às diversas respostas negativas recebidas frente às carências e demandas já apresentadas pelas pessoas. Faltam respostas no âmbito da saúde, reabilitação, educação, trabalho, lazer e cultura. Se não há soluções, as demandas também se calam. Estas puderam ser resgatadas nos diálogos, nas entrevistas, nas relações interpessoais de confiança estabelecidas no Grupo de Convivência Vida Nova, onde a comunicação foi estimulada, e mesmo tímida, pôde dar voz a alguns pedidos de ajuda. A possibilidade de conhecer o cotidiano das pessoas entrevistadas ofereceu elementos para discutirmos as demandas apresentadas, algumas verbalizadas explicitamente, outras percebidas em meio aos diálogos e comportamentos estabelecidos no momento da entrevista e no grupo de convivência. Muitas destas demandas coincidem com as categorias apresentadas na discussão sobre o tema cotidiano, sendo as demandas de conversar e passear, as mais destacadas pelos participantes.

Marisa iniciou a entrevista verbalizando que "está mais calma, ficava nervosa, pois não tinha atividade para fazer”. Os passeios e as saídas semanais lhe 
promoviam tranquilidade. Verbalizou que “queriam me internar, internar, eu não queria!”, revelando o medo de ser apartada do convívio familiar. Em outro momento disse que gostava de conversar (o que também observamos no grupo de convivência), e verbalizou sentir solidão quando permanece sozinha em casa e, quando isso ocorre, só lhe resta assistir a novela.

O desejo de sair de casa também foi a tônica do discurso de Rosa. "Mas ficar dentro de casa tá sendo um caos para mim”. E diz o quanto sente falta de conversar: (...)eu sinto muito a falta de alguém que converse comigo, porque eu fico sozinha, não tem com quem conversar, aí, só vejo as paredes (...).

Adriano também falou dessas necessidades; quer conversar, passear e namorar. Iniciou seu discurso afirmando que em sua vida "não tem brincadeira $e$ acredita que não tem como procurar". Afirmou que a dificuldade é a falta de um carro e de apoio (de amigos e familiares) para sair. Verbalizou diversas vezes que “queria mesmo sair, passear, ir pros lugares legais”, conversar com os primos, dos quais sente muita saudade.

Nós, na condição de interlocutores e representantes de um serviço de saúde, compreendemos essas falas como demandas. Pedidos que foram endereçados a nós, terapeutas ocupacionais, que produzimos formas alternativas de assistência em reabilitação, enfatizando a participação comunitária e o acesso a direitos. Portanto, essas demandas foram estimuladas, também, a partir de certa oferta de assistência, que temos produzido nos últimos cinco anos. Aqui, portanto, parece haver um diálogo entre demandas e produção de assistência, que, neste caso, não está focada apenas na intervenção em saúde. 
Acreditamos que o Grupo de Convivência Vida Nova tenha sido um espaço privilegiado para realizar trocas sociais e afetivas. A conversa, presente em todos os encontros, inicialmente entre participantes, profissionais e estagiários e ao longo da experiência entre os participantes do grupo, foi um dos aspectos que motivou a participação.

As saídas para o centro da cidade, bem como os demais passeios realizados, foram atividades que marcaram positivamente os participantes. Relatos como o de Antonia sobre o passeio que realizou ao pico do Jaraguá: “foi tudo maravilhoso”, ou de Marlene, com relação ao filho Osmar: "ele fica doidinho quando vai para a Vinte e Cinco de Março". E mesmo quando Adriano, de modo enfático e insistente, solicitou à terapeuta outras oportunidades para passear e lembrou-se dos passeios realizados como momentos de viver a vida em sua plenitude e intensidade. Foi num dos grupos de convivência que encontrou sua namorada, e com ela estabeleceu um relacionamento inédito e intenso, que o colocou diante de medos e incertezas, questões inerentes à condição humana, e que só podem ser precipitadas através do encontro com o outro.

O trabalho também se caracterizou como uma das demandas apresentadas pelos entrevistados, protagonizada principalmente por Osmar. Para o jovem, a demanda por trabalho e dinheiro é a tônica do seu cotidiano. Ser trabalhador é uma qualidade reconhecida pela comunidade e incentivada pelos familiares.

$\mathrm{Na}$ impossibilidade de trabalhar, condição presente para alguns dos entrevistados, a demanda pelo recebimento do benefício de prestação continuada é uma necessidade urgente, postergada por mecanismos burocráticos que obstaculizam o acesso a um direito social. Esta é a condição de Antonia, que na primeira fala de 
sua entrevista endereçou à terapeuta o pedido de ajuda para aquisição do beneficio: “A minha alegria vai ser eu conseguir a aposentadoria e viajar... eu vou embora lá pra Bahia”.

Novamente enfatizamos que o grupo não tem o objetivo de gerar renda; portanto, não podemos responder à inquietude de Osmar quanto à necessidade de “ganhar dinheiro”. Porém abordamos algumas condições necessárias para o enfrentamento da vida: a aprendizagem de conceitos básicos (noção de tempo, de quantidades, números, entre outros), o exercício de responsabilidade e de maturidade emocional, aquisições no campo da comunicação e das condições de sociabilidade. Acreditamos na aquisição de conhecimentos e habilidades, que promovam maior grau de autonomia nos sujeitos, bem como a possibilidade de realizar escolhas e recusas. Para Osmar, seria uma forma de defesa, que o fortaleceria diante das situações de riscos pessoais vivenciadas em seu cotidiano.

Quanto à demanda por benefícios da previdência, procuramos apoiar as famílias nos encaminhamentos junto à assistência social da Unidade Básica de Saúde e às equipes de saúde, para prover laudos e exames que possibilitem o acesso ao recurso e justifiquem a necessidade do recebimento do apoio financeiro.

Alimentação e moradia também apareceram como demandas importantes. Os pedidos por comida, pronunciados por Osmar durante o grupo de convivência, indicavam a urgência e a precariedade das condições de vida de alguns sujeitos. Afinal, como lidar com a fome de Osmar? Fome de quê? De alimento? De atenção? De cuidados? De oportunidades? De direitos? O grupo não pôde oferecer comida ao jovem, porém, acreditamos que o nutrimos de outras formas, através da continência de suas inquietudes, da valorização do seu fazer e da interlocução realizada entre 
familiares e comunidade em geral, promovendo situações nas quais Osmar pôde ser visto como alguém que tem habilidades.

Adriano, durante entrevista, revela o descontentamento com relação a sua moradia. Local inacessível para cadeira de rodas. Externalizou o desejo de reformálo, “tapar buracos, pintar, trocar de telha, fazer muro". Deseja também comprar uma cadeira de rodas motorizada, como a vista na Reatech (feira de equipamentos e recursos tecnológicos para pessoas com deficiência ). "O que eu queria mesmo era comprar uma cadeira motorizada, né, (...) se eu tivesse dinheiro mesmo assim eu comprava, né. (...) Se eu tivesse, primeiramente eu ia, (...) eu ia cimentar ali na frente, né, pra não quebrar, fazer rampa aí, (...), adaptar aí o solo.

A demanda por uma moradia isenta de barreiras arquitetônicas é uma necessidade urgente para Adriano e a reforma da casa está no rol das prioridades de sua vida. Ao sair de casa e conhecer outras possibilidades, deparou-se com a existência de uma cadeira de rodas motorizada, que, em sua opinião, facilitaria sua locomoção, outra demanda importante indicada pelo rapaz. Em outras dimensões, a questão da precariedade das condições de moradia está presente na vida de Antonia (que mora em casa com um cômodo e paga aluguel) e para Osmar e Rosa, que não possuem autonomia em suas moradias.

Alimentação, moradia e locomoção estão entre os tipos de necessidades relacionadas a condições de vida e à possibilidade de viver com autonomia e realizar escolhas. Sem essas condições essenciais, a vida se torna frágil e inviável, indicando a existência de um abismo entre as experiências cotidianas destes sujeitos e o exercício da cidadania. 
Essas contradições estiveram presentes em diversas situações colocadas ao grupo de convivência: observamos a precariedade de algumas moradias nas visitas domiciliares, as dificuldades de acessibilidade para pessoas com deficiência física durante a circulação pelo bairro e pela cidade, notamos a dificuldade de utilizar o ônibus adaptado. Porém, no contexto do grupo de convivência, o que era possível produzir, em contraposição a todas estas faltas?

Em primeiro lugar, era necessário dar visibilidade a estas questões. Como disse a voluntária Tia Mia: “nós nem sabíamos que existiam tantos deficientes na comunidade!” Portanto, era necessário promover a circulação destas pessoas pelos espaços públicos, e assim, confrontar as suas condições aos recursos da comunidade (materiais e humanos). Sensibilizar a população e a própria pessoa com deficiência e seus familiares sobre os direitos sociais, bem como discutir modos de promovê-los, foi um caminho possível para lidar com tantas faltas. No grupo de convivência, promovemos o encontro entre sujeitos com experiências semelhantes, estimulamos o reconhecimento das necessidades individuais como demandas coletivas, promovemos o acesso às informações e fomentamos as discussões sobre as necessidades, a partir da ótica das pessoas com deficiência. A experiência da organização de um encontro entre representantes do poder público local e as pessoas com deficiência pode ser citada como um exemplo das ações possíveis de serem produzidas no âmbito das reivindicações sociais. Segundo Pinheiro, Guizardi, Machado e Gomes (2005), é necessário dar voz aos sujeitos para que demandas sejam compreendidas como direito: “... o caminho de compreender as demandas em relação à construção do direito à saúde requer considerar a linguagem como uma das 
mais importantes mediações na produção do que se reconhece como necessidade” (p. 26).

No campo do direito à saúde, enfatiza-se a garantia de acesso a todas as tecnologias que melhorem ou prolonguem a vida (Cecílio, 2001). Para algumas pessoas com deficiência entrevistadas, a demanda por tratamento de reabilitação seria uma resposta ao não agravamento das condições de incapacidade. Demanda legítima, porém muitas vezes negada. Adriano possui amigos que realizam tratamento de hidroterapia em serviço público, o que o estimulou a procurar tal recurso. Porém, aguarda em lista de espera. Segundo ele: "tô louco pra fazer terapia, né? Fisio d'água, terapia d'água”. Para a mãe, que divide a angústia da espera junto com o filho, "Eu só não pago pra fazer, porque eu não tô podendo agora... porque se eu achasse isso aí, e tivesse negócio de água também, eu pagava”.

Marisa também verbalizou o desejo de realizar reabilitação física e estudar, experiências que não foram possíveis na infância e na juventude. Para uma mulher adulta com deficiências intelectuais e físicas importantes, o tratamento em reabilitação e o ingresso em escola são demandas que necessitam ser mais bem elaboradas e compreendidas. $\mathrm{O}$ que se percebe é que, embora muito imatura emocionalmente, é claro o seu desejo de ser cuidada e investida. Nesse sentido, o grupo de convivência pode ser pensado como uma alternativa às demandas de Marisa. Não realizamos reabilitação física clássica, tampouco oferecemos educação formal. Porém, a partir das atividades desenvolvidas no grupo, temos percebido melhoras em sua maneira de caminhar e executar as atividades manuais, decorrentes do estímulo à realização de atividades com autonomia e não do treino da atividade manual ou da marcha. Também temos observado aquisições no aspecto cognitivo e 
emocional dos participantes, o que nos leva a afirmar que a participação comunitária num grupo de convivência pode gerar aprendizado mesmo em adultos com deficiências graves.

A demanda de estudar foi endereçada a nós de diversas maneiras: Osmar dirigia-se ao quadro negro presente na sala e "desenhava bolinhas", que para ele representavam palavras. Diante dos avisos sobre os passeios, o jovem mostrava-se inquieto e dizia: “eu não sei ler!” E pedia para que terapeuta intermediasse o contato com a família. Adriano compareceu ao grupo com uma pasta que continha documentos sobre o movimento de pessoas com deficiência e pediu para que nós os lêssemos e lhe transmitíssemos o conteúdo.

Interpretamos essas situações como sendo o desejo de aprender a ler e escrever, reconhecer símbolos, letras e números, que são importantes para a manutenção da vida cotidiana: assinar um documento, saber contar, reconhecer valores monetários, identificar o letreiro do ônibus, administrar o próprio benefício, ter acesso às informações escritas. Porém para a maioria deles, adultos, sem experiência educacional, aprender se tornou um grande desafio, que também gera medos e incertezas.

Uma alternativa para os adultos com deficiência que não tiveram a oportunidade de estudar no passado são os cursos de alfabetização de adultos, que, segundo Neri (2003), têm sido bastante procurados por pessoas com deficiências: 32\% do total de matriculados. No bairro Cohab Raposo Tavares existe o projeto MOVA. No segundo semestre do ano de 2006, Osmar passou a frequentar o curso de alfabetização de adultos, fato que foi precipitado por sua circulação no centro comunitário e o convite, por parte da professora, para que ele participasse de um dos 
grupos. Na entrevista individual, este foi o primeiro tema abordado pelo jovem, que revelou a importância de mais esta experiência comunitária. Outros dois jovens com deficiência já freqüentavam o projeto de alfabetização, que, por ocorrer na comunidade, tem o acesso facilitado.

Todas estas demandas, para serem respondidas, dependem de mediações, de apoio concreto, do acesso às informações e da implementação de políticas públicas intersetoriais. Uma forma de lidar com essas necessidades seria a ampliação da rede de apoio social, composta por familiares, amigos, recursos comunitários e profissionais que estejam sensíveis a essas demandas.

Concordamos com Sluzki (1997), ao dizer que a existência de uma rede de apoio social ativa e efetiva atua positivamente na saúde dos sujeitos e que situações como a existência de doenças crônicas e deficiências podem gerar a retração destas redes. Em nosso estudo, entramos em contato com cuidadoras de pessoas com deficiência que exercem essa função de forma solitária e que já demonstram sinais de estresse físico e psíquico.

Acreditamos que o Grupo de Convivência Vida Nova passou a compor a rede de apoio social dos sujeitos que dele participaram. Sluzki (1997), ao discutir o modelo da rede social, sistematizou as funções da rede como sendo:

$>$ companhia social, ou seja, a possibilidade de estar junto e realizar atividades conjuntas;

$>$ apoio emocional, presente em relações com predomínio da compreensão, simpatia e empatia; 
$>$ guia cognitivo e de conselhos, relações interpessoais com troca de informações pessoais e coletivas, esclarecimento de expectativas e oferecimento de modelos sociais;

regulação social, cumprimento de papéis em concordância com as regras sociais de convivência que pode afastar os sujeitos da violência e formas degradantes de relação interpessoal;

ajuda material e de serviços, que inclui a assistência realizada através dos serviços e dos profissionais de saúde e outros setores, sendo componentes importantes da rede e

$>$ acesso a novos contatos, a ampliação da rede, novas conexões.

O Grupo de Convivência Vida Nova promoveu o encontro entre os sujeitos, num clima de empatia e simpatia, na tentativa de compreender as demandas apresentadas pelos sujeitos. Nele, são cambiadas experiências e informações, conversamos sobre temas como direitos sociais e são treinadas habilidades para o convívio social. A participação em um grupo também pode ser um fator de proteção social: durante os encontros, Osmar pôde verbalizar sobre medos e conflitos existentes no âmbito familiar. A ajuda material e de serviços pode ser exemplificada nas intermediações que o grupo realizou com serviço de saúde local, bem como com outros recursos como o centro comunitário, o setor de transporte coletivo municipal, o setor de dispensação de órteses e próteses do Sistema Único de Saúde, entre outros.

O que se pode afirmar, com este estudo, é a necessidade de permanência deste tipo de trabalho, não apenas promovido pela iniciativa de um serviço de saúde, mas incorporado a centros sociais e a outras experiências comunitárias, que articulem 
diferentes setores como a cultura, o lazer, a educação, o transporte, entre outros, que dialoguem com as demandas colocadas pelas pessoas com deficiência.

Considera-se importante a realização de outros estudos no campo da reabilitação com ênfase no território, que investiguem outras formas e estratégias de intervenção na comunidade, junto às pessoas com deficiência. O acesso aos cuidados em saúde e reabilitação não tem sido a realidade para muitas pessoas que residem em áreas periféricas, sendo fundamental se pensar em estratégias locais que dialoguem com as demandas colocadas por essas pessoas. Para a Terapia Ocupacional, a intervenção comunitária em reabilitação tem se tornado um campo importante de ensino, pesquisa e assistência, sendo necessários maiores investimentos para a divulgação e implementação desta prática. 


\section{CONCLUSÕES}


As demandas das pessoas com deficiência expressam a vivência de processos de exclusão e de invalidação social. Em nosso estudo, entramos em contato com realidades distintas e demandas diversas. As pessoas com deficiência desejam passear e conversar, ter uma moradia digna e aconchegante, ter alimento, trabalho, benefício previdenciário, locomover-se e realizar tratamento em reabilitação, principais demandas apresentadas pelos participantes e que estão relacionadas a garantia de condições de vida com dignidade e emancipação das pessoas com deficiência.

O Grupo de Convivência Vida Nova foi compreendido como uma alternativa assistencial em reabilitação que promoveu a ampliação da rede de apoio social das pessoas envolvidas, entendida como fator de proteção social de sujeitos que vivenciam situações de isolamento domiciliar. Ter apoio social, significa estar mais fortalecido diante das situações difíceis impostas pelo cotidiano, a melhora da auto estima e da autonomia pessoal.

Nesse estudo, procuramos promover um diálogo entre as demandas colocadas pelas pessoas com deficiência e a estratégia do grupo de convivência como uma alternativa para lidar com esses pedidos. Consideramos o bairro como cenário de desenvolvimento do grupo e ao oferecermos escuta às demandas dos sujeitos, os pedidos extrapolaram o campo da reabilitação e da saúde.

Sabemos que as experiências territoriais em reabilitação são escassas em nosso país, apresentamos uma experiência inédita e singular, que pode ser questionada quanto às possibilidades de sua manutenção e viabilidade no âmbito do serviço de saúde, ou ainda de sua reprodução em outros contextos. No entanto, enfatizamos a responsabilidade dos serviços de saúde, principalmente aqueles com 
inserção territorial e comunitária, de promover a escuta e acolhimento das demandas desta população; articular serviços e se responsabilizar pela criação de alternativas assistenciais em reabilitação em consonância com esse cenário, promovendo a participação comunitária e a garantia dos direitos sociais. 
8 ANEXOS 


\subsection{Anexo 1 - TERMO DE CONSENTIMENTO LIVRE E ESCLARECIDO}

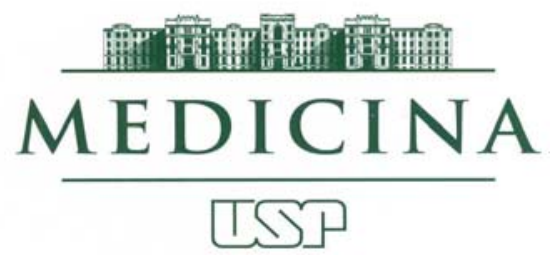

FACULDADE DE MEDICINA DA UNIVERSIDADE DE SÃO PAULO

Departamento de Fisioterapia, Fonoaudiologia e Terapia Ocupacional

Curso de Terapia Ocupacional

O (A) senhor (a) está sendo convidado a participar da pesquisa "Reabilitação com ênfase no território - promovendo a participação comunitária das pessoas com deficiência” realizada por Marta Aoki com supervisão da Prof. Dra. Fátima Corrêa Oliver. O estudo será realizado através de entrevistas no domicílio, com pessoas com deficiência e seus familiares, com idade entre 18 e 60 anos. As entrevistas serão gravadas em áudio e tratam sobre condições de saúde, reabilitação, educação, trabalho, situação econômica, lazer e cultura, locomoção e apoio social das pessoas com deficiência.

O estudo envolve, também, a observação das atividades do Grupo de Convivência realizado no Centro Comunitário Raposo Tavares.

Na entrevista, o (a) senhor (a) tem a liberdade de responder às perguntas que considerar significativas e o direito de não responder àquelas que não desejar. Seu nome será mantido em sigilo, para garantir privacidade e o (a) senhor (a) terá a liberdade de deixar de participar do estudo se assim desejar.

As entrevistas e as observações das atividades não causam riscos ou danos à saúde.

Qualquer dúvida ou reclamação favor entrar em contato com o Comitê de Ética em Pesquisas da Secretaria Municipal da Saúde de São Paulo, Rua General Jardim, 36, $2^{\circ}$ andar. Telefone: 32181013 - e-mail: smscep@prefeitura.sp.gov.br.

\section{Identificação dos pesquisadores:}

Prof. Dra. Fátima Corrêa Oliver - CREFITTO 3/455 TO

Marta Aoki - CREFITO 3/4617 TO

Curso de Terapia Ocupacional da FMUSP - Depto de Fisioterapia, Fonoaudiologia e Terapia Ocupacional

Rua Cipotânea, nr. 51, $1^{\circ}$ andar, sala 03 - Cidade Universitária CEP 05360-160 São Paulo - SP - Tel 30917457

Identificação do participante ou responsável legal 
1. NOME DA PESSOA

DOCUMENTO DE IDENTIDADE $\mathrm{N}^{\circ}$ SEXO: ( )M ( )F

DATA DE NASCIMENTO:..................

ENDEREÇO:.

BAIRRO:. CIDADE:

CEP:.

TELEFONE

2. RESPONSÁVEL LEGAL:

NATUREZA (grau de parentesco, tutor, curador, etc...). DOCUMENTO DE IDENTIDADE N ${ }^{\circ}$ SEXO: ( )M ( )F

DATA DE NASCIMENTO:..................

ENDEREÇO:.

BAIRRO:. CIDADE:

CEP:.

TELEFONE.

Eu, abaixo assinado, estou esclarecido sobre os objetivos do estudo e:

口 Autorizo a observação de minhas atividades no Grupo de Convivência

Concordo em participar da entrevista gravada em áudio.

São Paulo, ...........de .de $200 . . .$.

Assinatura do participante da pesquisa Assinatura do pesquisador ou responsável legal 


\subsection{Anexo 2 - ROTEIRO DE ENTREVISTA INDIVIDUAL}

NOME:

EDEREÇO

TELEFONE

FILIAÇÃO

RESPONSÁVEL

DATA DE NASCIMENTO:

ÁREA

PRONT. USF:

SEXO: ( )MASC ( ) FEM

DATA RG:

ENTREVISTADOR:

INFORMAÇÕES SOBRE CONDIÇÃO DE SAÚDE

- Existência de problemas de saúde atuais, crônicos, eventos desta natureza que foram significativos para o usuário.

INFORMAÇÕES SOBRE A DEFICIÊNCIA OU INCAPACIDADE

-Tipo de deficiência, quando foi percebida, detectada e por quem foi percebida ou detectada

- enfrenta algum tipo de dificuldade em consequêencia da deficiência ou incapacidade? De que tipo?

- Como tem feito para lidar com essa dificuldade? Dê um exemplo

\section{SOBRE ATENÇÃO A SAUDE OU REABILITAÇÃO}

- Realiza ou realizou algum tipo de acompanhamento ou tratamento? Onde? (tipo de serviço: ambulatório de especialidades, hospital geral, centro de reabilitação, o serviço era público ou privado). E por quanto tempo cada um deles? Esses acompanhamentos contribuíram para lidar com os problemas advindos da deficiência/incapacidade? Se sim como? Se não por que?

- Se não passou ou interrompeu o tratamento, qual foi o motivo?

- Atualmente sente necessidade de algum tipo de acompanhamento? Se sim de que tipo? Se não por que?

EDUCAÇÃO

- É alfabetizado? Estuda ou já estudou? Onde? Descreva como se deu sua experiência escolar?

\section{ATIVIDADES DE AUTO CUIDADO}

- Descreva como realiza atividades de auto cuidado alimentação, higiene, vestuário e organização de seu domicílio.

- Necessita de ajuda? De que tipo? Quem o auxilia no dia a dia? Grau de parentesco

- Quem o tem auxiliado nos últimos dias? Nome e grau de parentesco

\section{MOBILIDADE}

- Desloca-se pela casa, pelo bairro, pela cidade? Como? Precisa de alguém que o auxilie? Quem?

Quem o tem auxiliado nos últimos dias? Nome e grau de parentesco

- Utiliza equipamentos de ajuda como cadeira de rodas, muletas etc? Como teve acesso a esses equipamentos e materiais?

- Utiliza transporte coletivo? Quando? Como? Para que tipo de atividades? Qual foram as últimas vezes em que utilizou esse transporte? Foi acompanhado de alguém? Quem? Qual o grau de parentesco?

- Tem passe livre para utilizar estes transportes?

TRABALHO

- Realiza ou já realizou alguma atividade profissional? Se sim, de que tipo e por quanto tempo? Onde? 


\section{COMPOSIÇÃO FAMILIAR E HISTÓRIA DA CHEGADA DA FAMÍLIA NO BAIRRO}

- Quem faz parte desta família? Quem mora nesta casa? Anotar uma lista com nome grau de parentesco, idade e há quanto tempo mora na casa.

- Como chegaram ao bairro? De onde vieram? Por que vieram para o bairro?

\section{VIDA ECONÔMICA}

- A pessoa ou a família tem renda? De que tipo? Quantas pessoas contribuem para a renda da família? Recebe algum benefício? Se sim de que tipo? Há quanto tempo? Como é administrada esta renda?

\section{O QUE GOSTA DE FAZER NO TEMPO LIVRE}

- Realiza atividades como esporte, passeios, artesanato, assistir televisão, entre outras? Se sim com que freqüência?

- Com quem costuma realizar atividades de lazer? Nome, idade e grau de parentesco

- Lembra-se do último passeio que realizou? Descreva-o (onde, quando, com quem, o que você achou do passeio)

- Para onde gostaria de passear? Por que e com quem?

VIDA SOCIAL

Participa de algum grupo, igreja, outros?

\section{APOIO E RELAÇÕES}

- Quando necessita de apoio, quem você procura (familiares, amigos, vizinhos, profissionais). Dê um exemplo de necessidade de apoio recente e com quem você pode contar

- Quem são as pessoas mais próximas a você no seu dia a dia?

- Com quem você mais conversa? Quem é seu melhor amigo?

- Tem ou já teve algum relacionamento afetivo (namoro, casamento, paquera). Fale sobre estes relacionamentos (tempo de duração, sentimentos, momentos alegres e difíceis do casal).

\section{SOBRE A PARTICIPAÇÃO NO GRUPO DE CONVIVÊNCIA}

- Como soube do grupo de convivência? Alguém lhe incentivou a participar? Quem?

- O que você acha de participar desse grupo?

- Se não manteve a freqüência ao grupo ou nunca participou embora tenha sido convidado, quais foram os motivos da não participação?

- Como é a preparação para ir ao grupo (cumprimento do horário, mobilização pessoal, necessidade de auxílio de outros, vestimenta, locomoção entre outras).

- Se você tivesse que contar sobre o grupo para alguém que não o conhece, como o descreveria?

- Com quem você mais conversa no grupo? Sobre o que vocês conversam?

- Fale das pessoas que participam do grupo, quem são e como é seu relacionamento com elas.

- Como foi o grupo na semana passada, o que você fez?

- Quais atividades que você mais gosta de fazer e em quais apresenta dificuldades para realizar.

- Alguém o ajuda?

- Você freqüenta o Centro Comunitário em outras atividades? O que você acha deste recurso?

\section{Observar:}

\section{CONDIÇÕES DE MORADIA E BARREIRAS ARQUITETÔNICAS E GEOGRÁFICAS}

- Tipo de construção e acesso a moradia. 


\subsection{Anexo 3 - ROTEIRO PARA OBSERVAÇÃO E REGISTRO DO GRUPO DE CONVIVÊNCIA}

Data:

Horário:

I - Participantes presentes

Pessoas da comunidade

Profissionais

II - Ambiente

Organização do espaço

Localização das pessoas neste espaço e deslocamentos realizados

Posição dos observados com relação ao observador

Deslocamentos no espaço de desenvolvimento do trabalho entre as pessoas

III - Desenvolvimento da atividade proposta

Momentos iniciais de delineamento do trabalho desenvolvido

Atividades propostas

Atividades realizadas

Relação entre participantes e a atividade proposta (como é realizada a atividade, que dificuldades podem ser observadas, relação do participante com o objeto produzido, apoio necessário para realizar a atividade entre outras)

IV - Comportamento dos sujeitos no grupo

Postura Corporal

Apresentação pessoal (vestuário, cuidado com o corpo)

Condutas explícitas e implícitas

Contato Visual

Toques corporais

V- Linguagem

Verbal e não verbal

Vocabulário, expressões utilizadas

Diálogos estabelecidos (temas levantados, discussões realizadas)

VI - Relacionamentos interpessoais

Entre os participantes

Entre participantes e observador

Comportamento e Participação do observador diante dos eventos observados

Como as ações dos participantes se relacionam com o que eles dizem que fazem

VII - Principais questões colocadas

No que diz respeito aos participantes

No que diz respeito às atividades

No que diz respeito à dinâmica do grupo

Demais observações 
9 REFERÊNCIAS 
Almeida AMG, Moraes BM, Barroso CMC, Barros MMM, Sampaio JJC. Oficinas em saúde mental: relato de experiências em Quixadá e Sobral. In: Costa CM, Figueiredo AC, organizadores. Oficinas terapêuticas em saúde mental: sujeito, produção e cidadania. Rio de Janeiro: Contra Capa; 2004. p.117-34.

Almeida MC. Deficiência e cotidiano: reflexos e reflexões sobre a reabilitação. Rev Ter Ocup Univ São Paulo. 1997;8(2/3):81-6.

Almeida MC. Saúde e reabilitação de pessoas com deficiências: modelos assistenciais [tese]. Campinas: Faculdade de Ciências Médicas da UNICAMP; 2000.

Andrade RBG, Vaitsman J. Apoio social e redes: conectando solidariedade e saúde. Cienc. Saúde Coletiva. 2003;7(4):925-34 [Citado em 14 abr. 2006]. Disponível em: http://www.scielo.br/pdf/csc/v7n4/14615.pdf

Ballarin MLGS. Abordagens grupais. In: Cavalcanti A. Terapia ocupacional fundamentação e prática. Rio de Janeiro: Koogan; 2007. p. 38-43.

Ballarin MLGS. Grupos de atividades: uma discussão teórico-clínica sobre o papel do terapeuta ocupacional [tese]. Campinas: Faculdade de Ciências Médicas da Universidade Estadual de Campinas; 2001.

Bardin L. Análise de conteúdo. Lisboa: Edições 70; 1977.

Barros S, Oliveira MAF, Silva ALA. Práticas inovadoras para o cuidado em saúde. Rev Esc Enferm USP. 2007;41(esp.):815-9.

Baumann Z. Comunidade, a busca por segurança no mundo atual. Rio de Janeiro: Zahar; 2003.

Bodstein R, Ramos CL, Hortale VA. Programa de reabilitação comunitária. Experiência de inclusão social da pessoa portadora de deficiência FUNLAR. Rio de Janeiro: FIOCRUZ; 2003.

Boff L. Saber cuidar: ética do humano - compaixão pela terra. 15a ed. São Paulo: Vozes; 2008.

Botti NCL. Oficinas em saúde mental: história e função [tese]. Ribeirão Preto: Universidade de São Paulo, Escola de Enfermagem de Ribeirão Preto; 2004.

Brandão SN, Costa LF. Visita domiciliar como proposta de intervenção comunitária. In Ribeiro, MA, Costa, LF. Família e problemas na contemporaneidade: reflexão e intervenções no grupo socius. Brasília: Universa; 2004. p.157-79.

Brasil, Ministério da Saúde. Coordenação de Atenção a Grupos Especiais. Programa de Atenção à Saúde da Pessoa Portadora de Deficiência. Atenção à pessoa portadora de deficiência no Sistema Único de Saúde: planejamento e organização dos serviços. Brasília: Secretaria de Assistência à Saúde; 1993. 
Brasil. Ministério da Saúde. Secretaria de Assistência à Saúde. Portaria n ${ }^{0}$ 728, de 09 de outubro; 2002.

Brinkmann G. Unpaid CBR work force: between incentives and exploitation. Asia Pacifc Disabil Rehabil J. 2004;15(1):90-4.

Bury T. Primary health care and community based rehabilitation: implications for physical therapy. Asia Pacifc Disabil Rehabil J. 2005;16(2):29-61.

Carvalho MCB, Paulo Netto J. Cotidiano: conhecimento e crítica. 7a ed. São Paulo: Cortez; 2007.

Cecílio LCO. As necessidades de saúde como conceito estruturante na luta pela integralidade e equidade na atenção em saúde. In: Pinheiro R, Matos RA, organizadores. Os sentidos da integralidade na atenção e no cuidado à saúde. Rio de Janeiro: IMS/UERJ; 2001. p. 113-26.

Cheausuwantave T. Community based rehabilitation in Thailand: current situation and development. Asia Pacific Disabil Rehabil J. 2005; 16(1):51-67.

Cieri P. Historia, evolución y estado actual de la RBC y la APS en la Argentina desde la perspectiva de terapia ocupacional. World Federation of Occup Ther Bul. 2005;51:3546.

Costa CM, Figueiredo AC, organizadores. Oficinas terapêuticas em saúde mental: sujeito, produção e cidadania. Rio de Janeiro: Contra Capa; 2004.

Costa LF, Brandão SN. Psicologia clínica e psicologia social comunitária: um espaço de diálogo e construção de saberes e fazeres. In: Fleury HJ, Marra MM. Intervenções grupais na saúde. São Paulo: Agora; 2005. p. 17-33.

DeCs: Descritores em Ciências da Saúde [citado em 25 jan. 2008]. Disponível em: http://decs.bvs.br/cgi-bin/wxis1660.exe/decsserver/

Diniz TMRG. O estudo de caso: suas implicações metodológicas na pesquisa em serviço social. In: Martinelli ML, organizadores. Pesquisa qualitativa, um instigante desafio. São Paulo: Veras Editora; 1999. p.41-58.

Ferreira ABH. Dicionário Aurélio básico da língua portuguesa. Rio de Janeiro: Nova Fronteira; 1988.

Fidler G, Fidler J. Occupacional therapy: a communication process in psyquiatry. New York: Macmillan; 1963.

Finkenflugel H. Stakeholders' influences in CBR projects in Southrn Africa. Asia Pacific Disabil Rehabil J. 2005;16(2):3-28.

Gabbay R, Costa CM, Silva MAB. Oficinas um fazer/conviver terapêutico. In: Costa CM, Figueiredo AC, organizadores. Oficinas terapêuticas em saúde mental: sujeito, produção e cidadania. Rio de Janeiro: Contra Capa; 2004. p. 261-82. 
Galhego JC. Observación, entrevista y grupo de discusión: el silencio de trés prácticas de investigación. Rev Esp Salud Publica. 2002;76(5):409-22. Disponível em: http://redalyc.uaemex.mx/redalyc/pdf/170/17076504.pdf

Galleti MC. Oficina em saúde mental: instrumento terapêutico ou intercessor clínico? Goiania: Editora UCG; 2004.

Garcia AS. Rehabilitación basada en comunidad, estratégia de derechos humanos y calidad de vida para las personas con discapacidad. World Federation Occup Ther Bull. 2005;51:47-51.

Gaskell G, Bauer MW, editores. Pesquisa qualitativa com texto, imagem e som, um manual prático. Tradução de Pedrinho A. Guareschi. 6a ed. Petrópolis: Vozes; 2007.

Guerra AMC. Oficinas em saúde mental: percurso de uma história, fundamentos de uma prática. In: Costa CM, Figueiredo AC, organizadores. Oficinas terapêuticas em saúde mental: sujeito, produção e cidadania. Rio de Janeiro: Contra Capa; 2004. p.23-58.

Heller A. O cotidiano e a história. 8a. ed. São Paulo: Paz e Terra; 2008.

Hunt SG. Participatory community practice: a community- based rehabilitation curriculum in occupational therapy and lessons leard through partnerships with undergraduate students. World Federation Occup Ther Bull. 2005;51:15-8.

Kebbe LM. O uso de atividade em grupos terapêuticos e suas especificidades: subsídios para o debate sobre grupos de terapia ocupacional [dissertação]. Ribeirão Preto: Escola de Enfermagem de Ribeirão Preto da Universidade de São Paulo, Departamento de Enfermagem em Saúde Materno Infantil e Saúde Pública; 2002.

Karsh UM. Idosos dependentes: famílias e cuidadores. Cad Saúde Pública. 2003;19(3):861-6.

Kinoshita RT. Contratualidade e reabilitação psicossocial. In: Pitta A. Reabiltiação psicossocial no Brasil. 2a ed. São Paulo: Hucitec; 2001.

Kronenberg F, Fransen H, Pollard N. The WFOT position paper on community-based rehabilitation: a call upon the profession to engage people affected by occupational apartheid. World Federation Occup Ther Bull. 2005;51:5-13.

Kuipers P, Kuipers K, Mongkolsrisawat S. Categorising CBR service delivery: the Roi et classification. Asia Pacific Disabil Rehabil J. 2003;14(2):128-46.

Kujawski GM. Crise do século XX. 2a ed. São Paulo: Ática; 1991.

Lima SAB. Participação social no cotidiano. 5a ed. São Paulo: Cortez; 1983.

Lima EA. Oficinas e outros dispositivos para uma clínica atravessada pela criação. In: Costa CM, Figueiredo AC, organizadores. Oficinas terapêuticas em saúde mental: sujeito, produção e cidadania. Rio de Janeiro: Contra Capa; 2004. p.59-81. 
Lobosque AM, Souza ME, organizadores. Atenção em saúde mental. Belo Horizonte: Secretaria de Estado de Saúde de Minas Gerais; 2006.

Maneechak W, Salorm S. Being Occupational therapy volunteers in the Lao people's democratic republic. World Federation Occup Ther Bull. 2005;51:27-30.

Marcelinno NC. Lazer e humanização. 8a ed. São Paulo: Papirus; 1983.

Mattos RA, Pinheiro R, organizadores. Construção social da demanda. Rio de Janeiro: CEPESQ/UERJ, ABRASCO; 2005.

Maximino VS. Grupos de atividades com pacientes psicóticos. São José dos Campos: Univap - Universidade do Vale do Paraíba; 2001.

Mazza MMPR, Lefévre F. Cuidar em família: análise da representação social da relação do cuidador familiar com o idoso. Rev Bras Cresc Desenvolv Human. 2005;15(1):1-10.

May T. Pesquisa social, questões métodos e processos. Porto Alegre: Artmed; 2004.

Melleti SMF. O relato oral como recurso metodológico de pesquisa em educação especial. In: Marquesine MC, Almeida MA, Omote S. Colóquios sobre pesquisa em educação especial. Londrina: Eduel; 2003. p.1-10.

Minayo MC, Sanches O. Quantitativo-qualitativo: oposição ou complementaridade? Cad Saude Publica (Rio de Janeiro). 1993;9(3):239-62.

Myezwa HM, Kumbusi,VRP. Participation in community based rehabilitation programmes in Zimbabwe: where are we? Asia Pacific Disabi. Rehabil J. 2003;14(1):18-29.

Neri M. Retratos da deficiência no Brasil. Rio de Janeiro: FGV/IBRE, CPS; 2003.

Neufeld P S. Home and community occupational therapy - a growing pratice area in the USA. World Federation Occup Ther Bull. 2005;51:19-26.

Nicácio MF. Oficinas terapêuticas. 2004. [mimeo].

Oliver FC, Almeida MC, Tissi MC, Castro LH, Formagio S. Reabilitação baseada na comunidade: construindo estratégias de ação no contexto sociocultural. Rev Ter Ocup Univ São Paulo, 1999;10(1):1-10.

Oliver FC, Aoki M, Tissi MC, Nicolau SM. Reabilitação com ênfase no território: Jardim D’Abril e Jardim Boa Vista. Rev Ter Ocup Univ São Paulo. 2003;14(3):141-6.

Oliver FC, Aoki M, Tissi MC, Vargem EF, Ferreira TG. A construção de processos participativos em reabilitação: da convivência ao exercício de direitos. Rev Interface. 2004;8(15):275-88.

Oliver FC, Aoki M, Tissi MC, Vargem EF, Ferreira TG. Oficinas de trabalho sociabilidade ou geração de renda? Rev Ter Ocup Univ São Paulo. 2002;13(3):86-94. 
Oliver FC, Aoki M, Tissi MC, Vargem EF, Ferreira TG. Oficinas de trabalho sociabilidade ou geração de renda? Rev Ter Ocup Univ São Paulo. 2002;13(3):86-94.

Oliver FC, Ghirardi MIG, Almeida MC, Tissi MC, Aoki M. Reabilitação no território: construindo a participação na vida social. Rev Ter Ocup Univ São Paulo. 2001;12(1/3):15-22.

OMS, OPS. CIF - Classificação internacional de funcionalidade, incapacidade e saúde. São Paulo: Editora da Universidade de São Paulo; 2003.

Pichon-Riviere E. O processo grupal. 4a ed. São Paulo: Martins Fontes; 1991.

Pinheiro R, Guizardi FL, Machado FRS, Gomes RS. Demanda em saúde e direito à saúde: liberdade ou necessidade? Algumas considerações sobre os nexos constituintes das práticas de integralidade. In Mattos RA, Pinheiro R, organizadores. Construção social da demanda. Rio de Janeiro: IMS/UERJ, CEPESC, ABRASCO; 2005. p. 11-31.

Raj JS, Metilda PL. Needs assessment of programmes integrating community based rehabilitation into health activities. Asia PacifIc Disabil Rehabil J. 2004;15(1):69-74.

Ribeiro RCF. Oficinas e redes sociais na reabilitação psicossocial. In: Costa CM, Figueiredo AC, organizadores. Oficinas terapêuticas em saúde mental: sujeito, produção e cidadania. Rio de Janeiro: Contra Capa; 2004. p.105-16.

Rojas D, Salinas PJO, Monzón Y, Contreras J. Programa de rehabilitación de base comunitária (RBC) en el estado de Mérida 1997-2000. MedULA Rev Facultad Med Univ Los Andes (Mérida, Venezuela). 1999;8(1-4): p. 34-39.

Samea M. Terapia ocupacional e grupos: em busca de espaços de subjetivação [dissertação]. São Paulo: Instituto de Psicologia da Universidade de São Paulo; 2002.

Sarraceno B. Libertando identidades: da reabilitação psicossocial à cidadania possível. Instituto Franco Basaglia, Belo Horizonte/Rio de Janeiro: Te Corá Editora; 1999.

Sharma M, Deepak S. A inter-country study of expectations roles, attitudes and behaviours of community-based rehabilitation volunteers. Asia Pacific Disabil Rehabil J. 2003;14(2):179-90.

Schraiber LB, Mendes-Gonçalves RB. Necessidades de saúde e atenção primária. In Schraiber, LB, Nemes MIB, Mendes-Gonçalves RB. Saúde do adulto: programas e ações na unidade básica. São Paulo: Hucitec; 1996. p.29-47. (Saúde em Debate, Série Didática).

Sluzki CE. A rede social na prática sistêmica: alternativas terapêuticas. São Paulo: Casa do Psicólogo; 1997.

Sousa CP, Jorge R CB. Falha no projeto: atividades reconstrutoras num grupo de terapia ocupacional. Rev Centro Estudos Ter Ocup. 2000;(5): p. 22-24. 
Souza LMS, Laurert L. Trabalho voluntário: uma alternativa para a promoção de saúde do idoso. Rev Esc Enferm USP. 2008;42(2):371-6.

Thomas M, Thomas MJ. Controversies on some conceptual issues in community based rehatilitation. Asia Pacific Disabil Rehabil J. 1998;9(1):19-24.

Tjandrakusuma $\mathrm{H}$. Towards the $21^{\text {st }}$ century: challenges for community based rehabilitation in Asia and the Pacific Region. Asia Pacific Disabil Rehabil J. 1998;9(1):p. 01-06 [cited 2005 Nov 1]. Available from: http://www.dinf.ne.jp/doc/english/asia/resource/apdrj/z13jo0100/z13jo0104.htm

Triviños ANS. Introdução à pesquisa em ciências sociais: a pesquisa qualitativa em educação. São Paulo; Atlas; 1987.

Valla VV, Guimarães MB, Lacerda A. Religiosidade, apoio social e cuidado integral à saúde: uma proposta de investigação voltada para as classes populares. In: Pinheiro MR, organizador. Cuidado: as fronteiras da integralidade. Rio de Janeiro: CEPESC, UERJ, ABRASCO; 2005.

Valla VV. Sobre Participação popular: uma questão de perspectiva. Cad Saude Publica. 1998;14(supl 2):7-18.

Víctora CG, Knauth DR, Hassen MN. A. Pesquisa qualitativa em saúde, uma introdução ao tema. Porto Alegre: Tomo Editorial; 2000.

Wee J. Rationale for an aproach to identifyng disable persons in community based rehabilitation projects. Asia Pacific Disabil Rehabil J. 2004;15(2):33-41.

Wong Un JA. Visões de comunidade e saúde: comunalidade, interexistência, e experiência poética [tese]. Rio de Janeiro: Fundação Oswaldo Cruz, Escola Nacional de Saúde Pública, Departamento de Endemias; 2002.

World Health Organization, International Labor Organization, United Nations Educational, Scientific And Cultural Organization. CBR: a strategy for rehabilitation, equalization of opportunities, poverty reduction and social inclusion of people with disabilities: joint position paper. Geneva; 2004.

Yin RK. Estudo de caso: planejamento e métodos. 3a ed. Porto Alegre: Bookman; 2005.

Zimerman DE, Osorio LC. Como trabalhamos em grupos. Porto Alegre: Artmed; 1997. 